\title{
Over-Expression of an ETR1/ERS1 Ethylene Receptor Chimera in
} Arabidopsis thaliana

\author{
Justin J. Mahoney
}

A thesis submitted to the Faculty of Graduate Studies and Research in partial fulfillment of the requirements for the degree of Master of Science

\author{
Ottawa-Carleton Institute of Biology \\ Carleton University \\ Ottawa, Ontario \\ Canada
}

(C) October 2004 


$\begin{array}{ll}\begin{array}{l}\text { Library and } \\ \text { Archives Canada }\end{array} & \begin{array}{l}\text { Bibliothèque et } \\ \text { Archives Canada }\end{array} \\ \begin{array}{l}\text { Published Heritage } \\ \text { Branch }\end{array} & \begin{array}{l}\text { Direction du } \\ \text { Patrimoine de l'édition }\end{array} \\ \begin{array}{l}\text { 395 Wellington Street } \\ \text { Ottawa ON K1A ON4 } \\ \text { Canada }\end{array} & \begin{array}{l}\text { 395, rue Wellington } \\ \text { Ottawa ON K1A ON4 } \\ \text { Canada }\end{array}\end{array}$

Your file Votre référence ISBN: 0-494-00783-4

Our file Notre référence

ISBN: 0-494-00783-4

NOTICE:

The author has granted a nonexclusive license allowing Library and Archives Canada to reproduce, publish, archive, preserve, conserve, communicate to the public by telecommunication or on the Internet, loan, distribute and sell theses worldwide, for commercial or noncommercial purposes, in microform, paper, electronic and/or any other formats.

The author retains copyright ownership and moral rights in this thesis. Neither the thesis nor substantial extracts from it may be printed or otherwise reproduced without the author's permission.
AVIS:

L'auteur a accordé une licence non exclusive permettant à la Bibliothèque et Archives Canada de reproduire, publier, archiver, sauvegarder, conserver, transmettre au public par télécommunication ou par l'Internet, prêter, distribuer et vendre des thèses partout dans le monde, à des fins commerciales ou autres, sur support microforme, papier, électronique et/ou autres formats.

L'auteur conserve la propriété du droit d'auteur et des droits moraux qui protège cette thèse. $\mathrm{Ni}$ la thèse ni des extraits substantiels de celle-ci ne doivent être imprimés ou autrement reproduits sans son autorisation.
In compliance with the Canadian

Privacy Act some supporting forms may have been removed from this thesis.

While these forms may be included in the document page count, their removal does not represent any loss of content from the thesis.
Conformément à la loi canadienne sur la protection de la vie privée, quelques formulaires secondaires ont été enlevés de cette thèse.

Bien que ces formulaires aient inclus dans la pagination, il n'y aura aucun contenu manquant. 


\begin{abstract}
Ethylene regulates seed germination (Ecker, 1995), seedling growth, leaf and petal abscission, fruit ripening and organ senescence in plants (Gamble et al., 2002). Five ethylene receptors exist in Arabidopsis thaliana, however, only two of these receptors, ETR1 and ERS1, have putative histidine-kinase domains (Gamble et al., 2002). The histidine-kinase domain is at the carboxy-terminus, while the ethylene binding domain is located at the amino-terminus (Bleeker and Kende, 2000). The etr1-1 mutant plants confer dominant ethylene insensitivity and their seeds experience difficulty in germinating (Ecker, 1995). In this project, a chimeric gene was constructed, whereby the transmembrane and GAF encoding domains of ETR1 were attached to the histidine-kinase encoding domain of ERS1. Site-directed mutagenesis was then performed on this gene to imitate the single base pair change that is found within the transmembrane encoding domain of the etr1-1 mutant allele. This chimeric gene was transformed into wild-type Arabidopsis plants. The transformed plants containing the single point mutation that imitated the etr1-1 mutant demonstrated a need for up to an additional five weeks in order to bolt. These mutants also demonstrated dwarf and semidwarf phenotypes with reduced rosette diameters as well as reduced stock heights at maturity. These mutants are similar to the gibberellic acid deficient mutants gai, sly and pkl that are either GA insensitive or have reduced GA biosynthesis (Fridborg et al, 1999). This may indicate that there is cross-talk between the ethylene and GA signal transduction pathways.
\end{abstract}




\section{Acknowledgments}

I would like to thank the Ottawa-Carleton Institute of Biology for giving me the opportunity to pursue my Master's Degree.

Words cannot express my sincere gratitude to my supervisor, Dr. John Vierula, for the generosity of his time, his dedication and his continued support. I would also like to thank Dr. Sharon Regan for her initiation and support of this project while at Carleton, and members of her lab for their cooperation \& help. I would also like to thank Nahideh Haghighi, Shuyou Han, Moshi Kotierk, Theresa Martin, Todd Mennie, Dr. Miguel Providenti, Arash Rashed, Dr. Alex Valencia and Bin Zhang for their help with this project. I would like to thank my advisory committee members, Dr. Guy Drouin and Dr. Myron Smith, and Dr. Tim Xing, for their suggestions and helpful comments on my thesis.

I am very thankful to Dr. William Willmore for his guidance and suggestions toward achieving my academic goals and to Dr. Mark Forbes for his continuing encouragement \& strong support.

I would like to thank all of my family, especially my brother James, my parents, my parents-in-law, my loving wife, Ana Maria, and my two dear children, Emma and Daniel. 


\section{Table of Contents}

TITLE.................................................................

ACCEPTANCE PAGE................................................................II

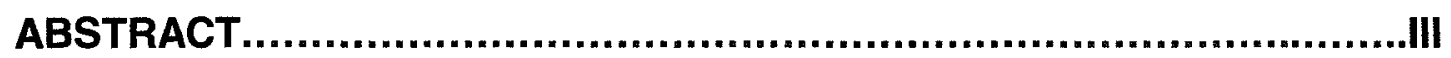

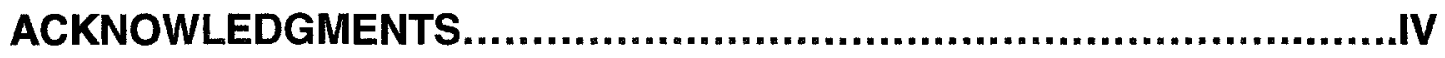

TABLE OF CONTENTS $\ldots \ldots \ldots \ldots \ldots \ldots \ldots \ldots \ldots \ldots \ldots \ldots$

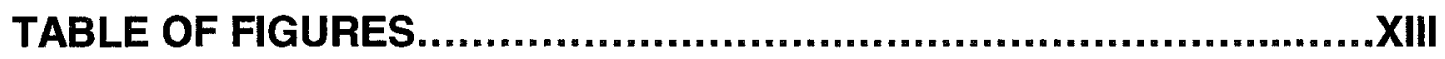

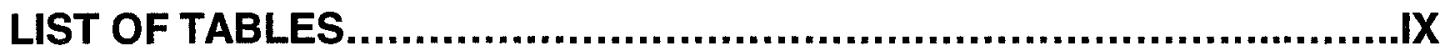

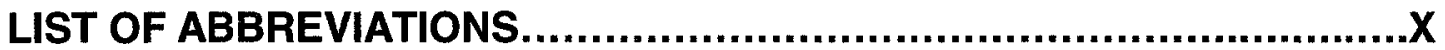

INTRODUCTION.................................................................

Arabidopis thaliana and the Function of Ethylene within this Plant.......1

Gain-of-Function Ethylene Receptor Mutants, Loss of Function Ethylene

Receptor Mutants and CTR1 Mutants......................................2

Ethylene Receptors, their Domains and Requirements for Signaling

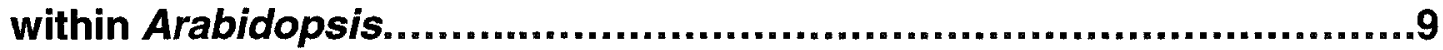

Ethylene Receptors as Two-Component Regulators.......................16

Other Proteins Involved in the Ethylene Signal Transduction

Pathway.......................................................................18

The Role of the Histidine Kinase Domain in Ethylene Receptors..........20

Arabidopsis Seeds, Seed Dormancy and Seed Germination............... 21

Plant Hormones and Their Effect on Seed Dormancy and Germination.23

Research Objectives and Experimental Hypothesis.........................25 


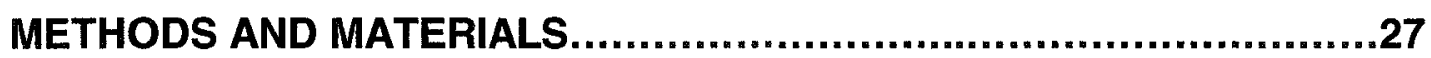

Isolation of RNA from Arabidopsis.............................................27

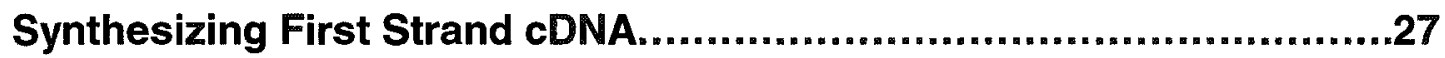

Designing Primers...................................................................28

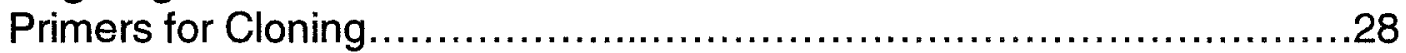

Primers for Confirming that the Inserts are in the Vector....................28

Primers for Performing Site-Directed Mutagenesis............................29

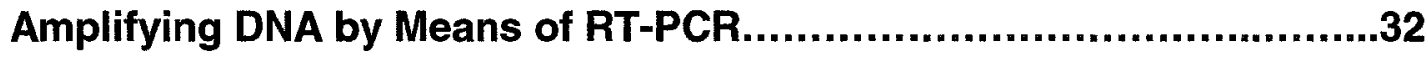

Performing Agarose Gel Electrophoresis.......................................33

Purifying PCR-Amplified Fragments............................................33

Cloning Fragments into pGEM-T囚 easy Vector..................................35

Ligating PCR-Amplified Fragments into pGEM-T® easy Vector...............35

Transformation of E.coli with Plasmid DNA ...................................37

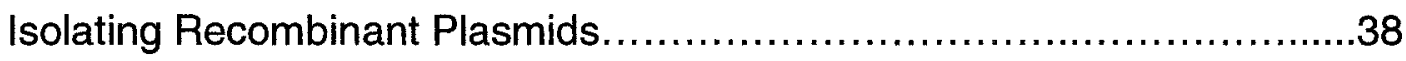

Bacterial Plasmid Miniprep.............................................. 38

Plasmid Isolation Using Wizard®Plus Midipreps (Promega) .................38

Digesting Recombinant Plasmids by Using the Restriction Enzymes

Ncol, Apal and BstEll.................................................................39

Digesting Recombinant Plasmids to Obtain the TMGETR1 and TMGERS1

Fragments.................................................................39

Digesting Recombinant Plasmids to Obtain the HKERS1 and HKETR1

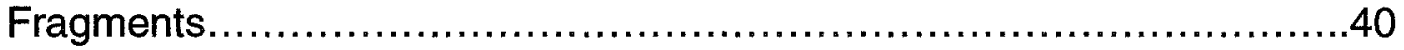

The Plant Transformation Vector - pCambia 1301 ............................41

Digesting pCambia 1301 with $\mathrm{Ncol}$ and BstEll to Prepare it Receive the

Inserts......................................................................................44

Preparing Agrobacterium tumefaciens (Strain LBA4404) Competent

Cells.......................................................................................44

Transforming Agrobacterium tumefaciens (Strain LBA4404) Competent Cells with the pCambia 1301 Recombinant Plasmid............................45

Sequencing the Inserts in the Recombinant pCambia 1301 Vector........45

Transforming Arabidopsis thaliana (Columbia ecotype).....................45 
Sterilizing and Imbibing Seeds..............................................47

Selecting Putative Transformants Using Antibiotic Selection................48

Maintaining the Appropriate Growing Conditions $\ldots . . . \ldots \ldots \ldots \ldots \ldots \ldots \ldots \ldots \ldots \ldots . \ldots 49$

Preparing E.coli Competent Cells...................................................49

Performing Site-Directed Mutagenesis......................................50

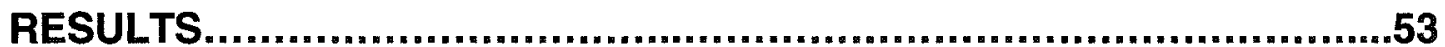

Assembly of the Chimeric Ethylene Receptors..................................53

Amplification of the ERS1 and ETR1 Fragments...........................56

Cloning of PCR Products into the pGEM-T®easy Vector.....................59

Assembly of Chimeric Ethylene Receptors into pCambia 1301.............62

Confirming the Presence of TMGETR1 and HKERS1 in pCambia1301...62

Sequence Analysis of the pCambia Recombinant Plasmids................66

Site-Directed Mutagenesis of the pCambia 1301 Construct..................71

Sequence Analysis of the Mutagenized Clones...............................74

Transformation with the pCam - TMGETR1/ERS1 Constructs.............78

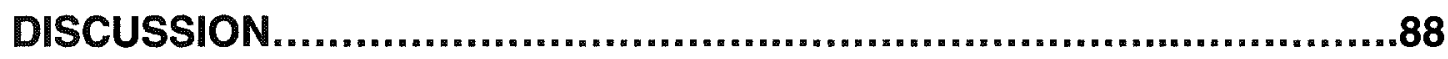

Ethylene Signal Transduction....................................................88

The Forward Genetics Approach.................................................89

Cloning Strategy..............................................................91

Conclusion: Implications of the Constructs of this Project.................98

References........................................................................102 


\section{Table of Figures}

Figure 1. Comparison of 3-Day-Old, Etiolated, Wild-Type Arabidopsis thaliana Seedlings, Grown in the Presence or Absence of Ethylene.......................6

Figure 2. Negative Regulation of the Ethylene Response $\ldots \ldots \ldots \ldots \ldots \ldots \ldots \ldots \ldots . . .7$

Figure 3. Schematic Representation of Interactions and Locations of Various Proteins within the Plant Cell Involved in the Ethylene Signal Transduction

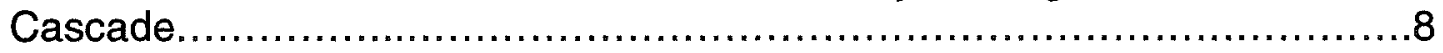

Figure 4. Arabidopsis thaliana Ethylene Receptor Proteins...................14

Figure 5. Autophosphorylation of ETR1 ....................................15

Figure 6. The Mechanism of Action of a Superfamily of Catalytic Receptors

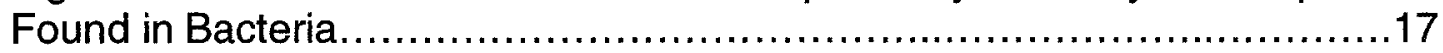

Figure 7. Diagram of Primer Locations in ETR1 and ERS1 Genes............31

Figure 8. Strategy for Cloning the Desired Fragments of ETR1 and ERS1...36

Figure 9. A Map of the Plant Transformation Vector, pCambia 1301..........42

Figure 10. pCambia 1301 T-DNA ...............................................43

Figure 11. Experimental Design for Sub-Cloning the TMGETR1/HKERS1

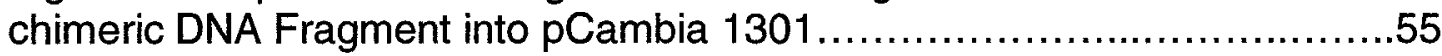

Figure 12. PCR Amplification of the ETR1 and ERS1 Fragments.............57

Figure 13. Evidence of the ETR1 and ERS1 Inserts in the pGEM-T®easy Recombinant Clones..........................................................61

Figure 14. Evidence of the ETR1 and ERS1 Inserts in pCambia $1301 \ldots \ldots \ldots 65$

Figure 15. Sequencing Results of the pCambia 1301 Construct...............68

Figure 16. The Plasmid Generated by Site-Directed Mutagenesis.............73

Figure 17. Sequencing of the Mutagenized Plasmid..........................75

Figure 18. Various TMGETR1/HKERS1 and tmgetr1-1/hkers1

Transformants. 


\section{List of Tables}

Table 1. Genes Involves in the Ethylene Signal Transduction

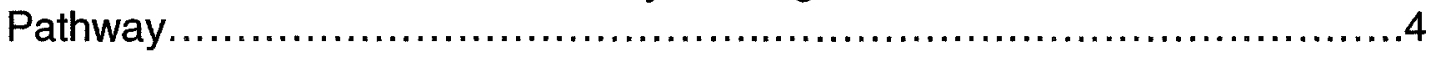

Table 2. Primers Used in this Project.........................................30

Table 3. Lengths of the Expected cDNA and Genomic DNA of the ETR1 and ERS1 Fragments.............................................................58

Table 4. Comparison of the Rosette Sizes and Stalk Heights of the tmgetr1-1

Transformants with a Wild-type Plant (ecotype Columbia) ...................87 


\section{List of Abbreviations}

$\begin{array}{ll}\text { ABA } & \text { abscisic acid } \\ \text { ACC } & \text { 1-aminocyclopropane-1-carboxylic acid } \\ \text { ATP } & \text { adenosine trophosphate } \\ \text { CamV 35S } & \text { cauliflower mosaic virus promoter } \\ \text { CDNA } & \text { complementary DNA } \\ \mathrm{C}_{2} \mathrm{H}_{4} & \text { ethylene } \\ \text { cys } & \text { cysteine } \\ \text { dNTP } & \text { deoxyribonucleotide triphosphate } \\ \text { EDTA } & \text { ethylene-diamine-tetra-acetic acid } \\ \text { EMS } & \text { ethyl methane sulfonate } \\ \mathrm{g} & \text { grams } \\ \mathrm{GUS} & \text { blue staining reporter gene } \\ \mathrm{Xg} & \text { acceleration due to gravity } 9.8 \mathrm{~m} / \mathrm{s}^{2} \\ \mathrm{hyg}(\mathrm{R}) & \text { hygromycin resistance } \\ \mathrm{kan}(\mathrm{R}) & \text { kanamycin resistance } \\ \mathrm{GA} & \text { gibberellic acid } \\ \mathrm{HCl} & \text { hydrogen chloride } \\ \mathrm{HKERS1} & \text { histidine kinase domain of ERS1 } \\ \mathrm{HKETR1} & \text { histidine kinase domain of ETR1 } \\ \mathrm{KCl} & \text { potassium chloride } \\ \mathrm{LB} & \text { Luria broth } \\ \mathrm{M} & \text { molar } \\ \mathrm{Mb} & \text { mega base pairs } \\ \mathrm{MgCl}{ }_{2} & \text { magnesium chloride } \\ \mathrm{MgSO}{ }_{4} & \text { magnesium sulfate } \\ \mathrm{ml} & \text { millilitre } \\ \mathrm{mM} & \text { millimolar } \\ \mathrm{MS} & \text { Murashige and Skoog } \\ \mathrm{N} & \text { normal } \\ \mathrm{NaCl} & \text { sodium chloride } \\ \mathrm{nm} & \text { nanometers } \\ \mathrm{Nt} & \text { nucleotide } \\ \text { oligo dT } & \text { oligothymidylic acid } \\ \mathrm{rpm} & \text { rounds per minute } \\ \mathrm{pCam-TMGETR1/ERS1} & \text { recombinant pCambia 1301 vector containing the } \\ \mathrm{RT}-\mathrm{PCR} & \text { TMGETR1 and HKERS1 encoding regions } \\ \mathrm{SDS} & \text { reverse transcriptase polymerase chain reaction } \\ \mathrm{TAE} & \text { sodium dodecyl sulfate } \\ \mathrm{TMGETR1} & \text { tris-acetate buffer } \\ & \text { transmembrane and GAF encoding regions of } \\ \mathrm{TMGERS1} & \text { ETR1 } \\ \mathrm{T} 0 & \text { transmembrane and GAF encoding regions of } \\ & \text { ERS1 } \\ \text { transformant seeds, unselected } \\ \end{array}$


$T_{1}$

$T_{2}$

Tyr

U

ug

ul

UTR

wt

X-gal first generation of transformants

second generation of transformants

tyrosine

units

micrograms

microlitres

untranslated region

wild type

5-bromo-4-chloro-3-indolyl- $\beta$-D-galactosidase 


\section{Introduction}

\subsection{Arabidopsis thaliana and the Function of Ethylene within this Plant}

Arabidopis thaliana was the first methylated eukaryotic genome to be sequenced (Arabidopsis Genome Initiative, 2000). The total length of the sequenced regions is $115,409,949$ base pairs, with an approximate genome size of $125 \mathrm{Mb}$ (Arabidopsis Genome Initiative, 2000). Approximately 25, 498 genes are predicted to occur in this genome and so far, 11, 601 proteins have been identified (Arabidopsis Genome Initiative, 2000). Also, sequence polymorphisms between coding and non-coding regions commonly occur between accessions of Arabidopsis (Arabidopsis Genome Initiative, 2000).

Ethylene is a fast-acting plant hormone that can diffuse freely from cell to cell across membranes and it does not require a transport factor. (Bleeker et al., 2000). Ethylene regulates seed germination, seedling growth, leaf and petal abscission, fruit ripening and organ senescence (Gamble et al., 2002). It is also involved in regulating seed germination (Chang et al., 1993). Ethylene acts as a signal to induce a plant's defence mechanisms (Stearns and Glick, 2003) and its synthesis is increased upon pathogen infection (Raz and Fluhr, 1993). However, it is not required for all pathogen resistances (Stepanova and Ecker, 2000).

During movement through the soil, seedlings develop a curvature in the hypocotyl, just below the cotyledons, known as an apical hook (Vriezen et al., 2004) that protects the delicate apical structures from damage as the seedlings emerge (McGrath and Ecker, 1998). The physical 
obstruction of the seedling's growth leads to an increase in ethylene biosynthesis in the plant. The excess ethylene causes the apical hook formation as well as the other characteristic features, known collectively as the 'triple response' or the 'ethylene response' (Ecker, 1995). This response occurs about three days after seed germination (Guo and Ecker, 2004). Other features of this response include, inhibition of hypocotyl and root elongation and radial swelling of the hypocotyl (Hua and Meyerowitz, 1998).

Ethylene is produced in most plant tissues (Stearns and Glick, 2003). ACC synthase is the limiting and regulating enzyme in ethylene biosynthesis (Bleeker and Kende, 2000). The expression of ACC synthase genes is activated by inducers, including ethylene (Ecker, 1995). Therefore, ethylene can stimulate its own synthesis by means of a positive feedback loop (Bleeker and Kende, 2000).

\subsection{Gain-of-Function Ethylene Receptor Mutants, Loss-of-Function Ethylene Receptor Mutants and CTR1 Mutants}

Ethylene insensitive mutants were discovered through screening mutagenized populations of Arabidopsis seedlings, grown in the dark, in the presence of applied ethylene. A mutant termed, ctr1, showed a constitutive ethylene response in the absence of ethylene (Bleeker and Kende, 2000). The constitutive triple response phenotype, observed in this mutant, can not be reversed by inhibitors of ethylene biosynthesis, suggesting that this mutant is defective in ethylene signal transduction (Ecker, 1995). It is believed that 
CTR1, along with the ethylene receptors, work together to negatively regulate the ethylene response pathway. Double mutants of the ctr1 gene and mutations of the ethylene receptors, which prevent the binding of ethylene, show a constitutive ethylene response. Therefore, it is likely that CTR1 acts downstream and is activated by the ethylene receptors in the absence of ethylene (Bleeker and Kende, 2000). Also, there is evidence that the ethylene receptors all act through CTR1 (Hua and Meyerowitz, 1998). 
Table 1. Genes Involved in the Ethylene Signal Transduction Pathway in

\section{Arabidopsis thaliana}

\begin{tabular}{|c|c|c|}
\hline $\begin{array}{l}\text { Gene/ } \\
\text { Allele }\end{array}$ & Property & Phenotype \\
\hline ETR1 & $\begin{array}{l}\text { Contains an ethylene sensing domain, a } \\
\text { putative histidine kinase domain and a } \\
\text { response regulator domain (Gamble et } \\
\text { al, 1998); negatively regulates the } \\
\text { ethylene response; localized to the } \\
\text { endoplasmic reticulum (Chen et al., } \\
\text { 2002) }\end{array}$ & $\begin{array}{l}\text { Normal ethylene } \\
\text { response and normal } \\
\text { germination }\end{array}$ \\
\hline etr1-1 & $\begin{array}{l}\text { Dominant, gain-of-function mutation; } \\
\text { Cys } 65 \text { toTyr; eliminates binding of } \\
\text { copper cofactor; found on chromosome } \\
\text { 1; reduced ethylene binding; contains an } \\
\text { ethylene sensing domain, a putative } \\
\text { histidine kinase domain and response } \\
\text { regulator domain }\end{array}$ & $\begin{array}{l}\text { Seedlings are insensitive } \\
\text { to ethylene i.e. no } \\
\text { ethylene response in } \\
\text { etiolated seedlings; } \\
\text { enhanced seed } \\
\text { dormancy (Beaudoin et } \\
\text { al., 2000) }\end{array}$ \\
\hline ERS1 & $\begin{array}{l}\text { Contains an ethylene sensing domain } \\
\text { and a putative histidine kinase domain; } \\
\text { negatively regulates the ethylene } \\
\text { response. }\end{array}$ & $\begin{array}{l}\text { Normal ethylene } \\
\text { response and normal } \\
\text { germination }\end{array}$ \\
\hline ers & $\begin{array}{l}\text { Dominant, gain-of-function mutation; } \\
\text { lle62 to Phe; reduced ethylene binding; } \\
\text { contains an ethylene sensing domain } \\
\text { and a putative histidine kinase domain }\end{array}$ & $\begin{array}{l}\text { No ethylene response in } \\
\text { etiolated seedlings; } \\
\text { reduced dormancy }\end{array}$ \\
\hline RAN1 & $\begin{array}{l}\text { Copper transporter required for the } \\
\text { delivery of } \mathrm{Cu}(\mathrm{I}) \text { cofactor to the ethylene } \\
\text { receptors }\end{array}$ & $\begin{array}{l}\text { Normal ethylene } \\
\text { response }\end{array}$ \\
\hline ran1 & $\begin{array}{l}\text { Null mutant; unable to deliver } \mathrm{Cu}(\mathrm{l}) \\
\text { cofactor to the ethylene receptors }\end{array}$ & $\begin{array}{l}\text { Constitutive ethylene } \\
\text { triple response observed } \\
\text { in etiolated seedlings }\end{array}$ \\
\hline CTR1 & $\begin{array}{l}\text { Raf-like serine/threonine kinase, putative } \\
\text { MAP kinase kinase kinase; activated by } \\
\text { ethylene receptors acting downstream to } \\
\text { negatively regulate the ethylene } \\
\text { response }\end{array}$ & $\begin{array}{l}\text { Normal ethylene } \\
\text { response and normal } \\
\text { germination }\end{array}$ \\
\hline ctr1 & $\begin{array}{l}\text { Family of null mutants; unable to } \\
\text { negatively regulate the ethylene } \\
\text { response }\end{array}$ & $\begin{array}{l}\text { Constitutive ethylene } \\
\text { response in etiolated } \\
\text { seedlings; enhances } \\
\text { ABA isensensitive, } \\
\text { reduced dormancy } \\
\text { mutant, abi1-1 } \\
\text { (Koornneef et al., 2002) }\end{array}$ \\
\hline
\end{tabular}




\begin{tabular}{|c|c|c|}
\hline EIN3 & $\begin{array}{l}\text { Positively regulated by EIN2; positively } \\
\text { regulates the ethylene response; family } \\
\text { of putative transcription factors; localized } \\
\text { to the nucleus }\end{array}$ & $\begin{array}{l}\text { Normal ethylene } \\
\text { response and normal } \\
\text { germination }\end{array}$ \\
\hline ein3 & $\begin{array}{l}\text { Recessive, family of loss-of-function } \\
\text { mutations; unable to positively regulate } \\
\text { the ethylene response }\end{array}$ & $\begin{array}{l}\text { Reduced ethylene } \\
\text { sensitivity i.e. reduced } \\
\text { ethylene response } \\
\text { observed in etiolated } \\
\text { seedlings }\end{array}$ \\
\hline EIN2 & $\begin{array}{l}\text { Negatively regulated by CTR1; a } \\
\text { cytoplasmic protein, related to the } \\
\text { Nramp family of metal transporters that } \\
\text { positively regulates the ethylene } \\
\text { response (Stearns and Glick, } 2003 \text { ); } \\
\text { transmits ethylene signal to EIN3 family } \\
\text { of transcription factors }\end{array}$ & $\begin{array}{l}\text { Normal ethylene } \\
\text { response }\end{array}$ \\
\hline ein2 & $\begin{array}{l}\text { Recessive, family of loss-of-function } \\
\text { mutations; unable to positively regulate } \\
\text { the ethylene response }\end{array}$ & $\begin{array}{l}\text { Complete ethylene } \\
\text { insensitivity (Alonso et } \\
\text { al., 1999) i.e. no ethylene } \\
\text { response observed in } \\
\text { etiolated seedlings; } \\
\text { enhanced seed } \\
\text { dormancy (Beaudoin et } \\
\text { al., 2000) }\end{array}$ \\
\hline $\begin{array}{l}a b i 1, \\
a b i 2, \\
a b i 3\end{array}$ & ABA-insensitive mutants & Reduced seed dormancy \\
\hline era1 & ABA-supersensitive mutant & $\begin{array}{l}\text { Enhanced seed } \\
\text { dormancy }\end{array}$ \\
\hline SIMKK & $\begin{array}{l}\text { Putative MAP kinase kinase in the } \\
\text { ethylene signal transduction pathway; } \\
\text { putatively, a positive regulator of the } \\
\text { ethylene response, negatively regulated } \\
\text { by CTR1 }\end{array}$ & $\begin{array}{l}\text { Normal ethylene } \\
\text { response and normal } \\
\text { germination }\end{array}$ \\
\hline SIMK & $\begin{array}{l}\text { Putative MAP kinase in the ethylene } \\
\text { signal transduction pathway; putatively, } \\
\text { a positive regulator of the ethylene } \\
\text { response, positively regulated by SIMKK }\end{array}$ & $\begin{array}{l}\text { Normal ethylene } \\
\text { response and normal } \\
\text { germination }\end{array}$ \\
\hline ERF1 & $\begin{array}{l}\text { Ethylene responsive; intermediate } \\
\text { target for EIN3; family of plant } \\
\text { transcription factors that binds GCC box, } \\
\text { a promoter motif of many ethylene and } \\
\text { pathogen induced genes (Guo and } \\
\text { Ecker, 2004) }\end{array}$ & $\begin{array}{l}\text { Overexpressing ERF1 } \\
\text { mimics subset of } \\
\text { ethylene responses (Guo } \\
\text { and Ecker, 2004) }\end{array}$ \\
\hline
\end{tabular}


Figure 1. Comparison of 3 Day-Old, Etiolated, Wild-Type, Arabidopsis thaliana Seedlings, Grown in the Presence or Absence of Ethylene (A) This drawing represents a seedling that has been grown in the dark, in the absence of ethylene. The hypocotyl is approximately $10 \mathrm{~mm}$ in height.

(B) This drawing represents an etiolated seedling, grown in the presence of ethylene, exhibiting the characteristic "Triple Response" phenotype. There is an inhibition of the hypocotyl and the root elongation. The hypocotyl is exhibiting thick radial growth and there is an exaggerated apical hook. The hypocotyl is approximately $4 \mathrm{~mm}$ in height. 

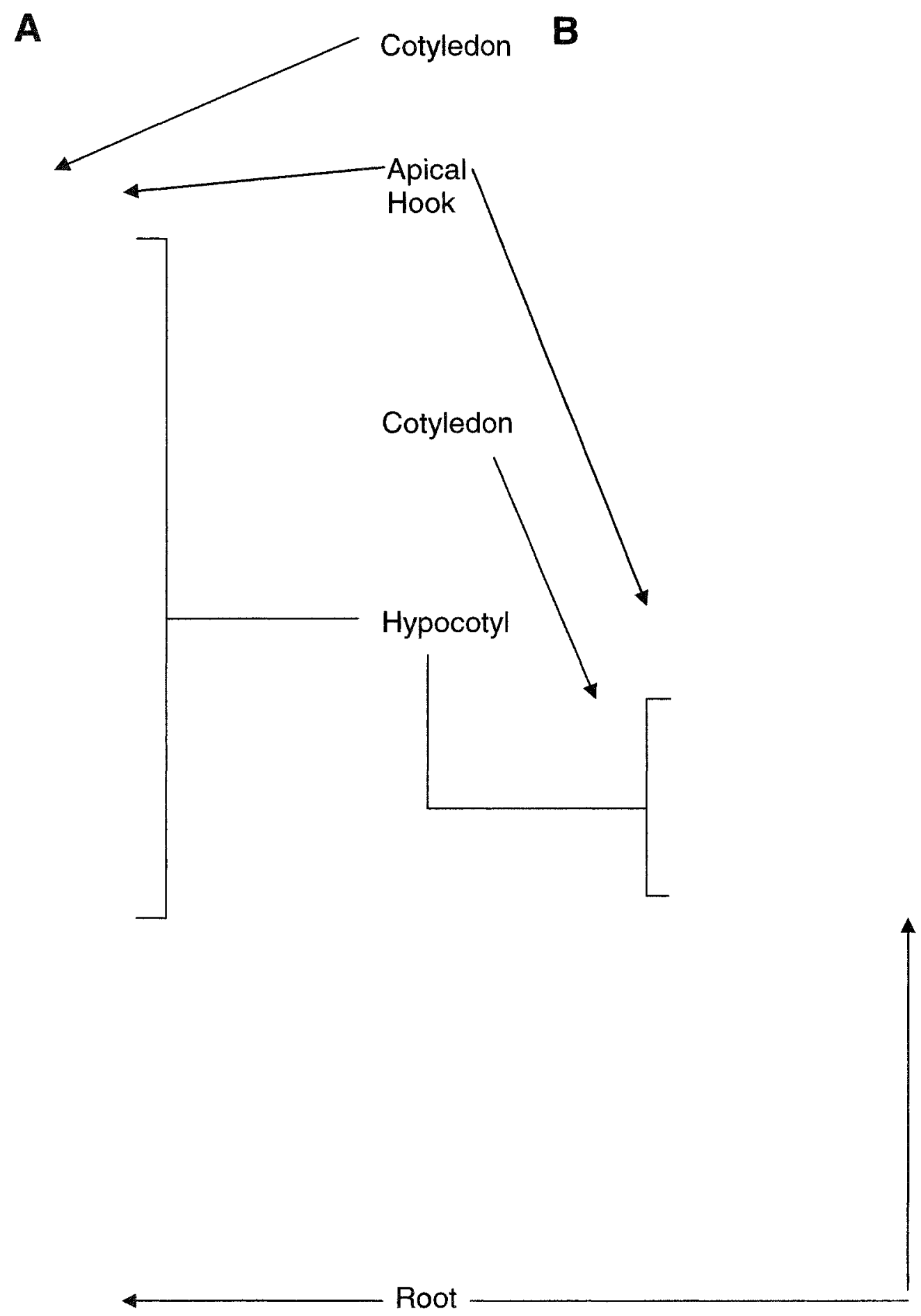
Figure 2. Negative Regulation of the Ethylene Response

(A) In this model, the ethylene receptors activate CTR1 in the absence of ethylene. As a result, CTR1 represses downstream regulators and the ethylene response is not observed (Bleeker and Kende, 2000).

(B) In the presence of ethylene, the ethylene receptors are inactivated. As a result, CTR1 is not active and cannot repress the downstream regulators. As, a result, the ethylene response is observed (Bleeker and Kende, 2000). 
A No Ethylene

ETR1

ERS1

ETR2

ERS2

EIN4

$\downarrow$

CTR1

$\perp$

SIMKK

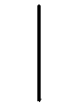

SIMK

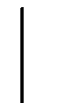

EIN2

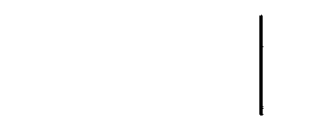

NO ETHYLENE RESPONSE OBSERVED
B Ethylene is present

$\mathrm{C}_{2} \mathrm{H}_{4}$

ETR1

ERS1

ETR2

ERS2

EIN4

I

CTR1

I

SIMKK

$\downarrow$

SIMK

$\downarrow$

EIN2

$\downarrow$

ETHYLENE RESPONSE

(Adapted from Ecker, 1995 and Ouaked et al., 2003) 
Figure 3. Schematic Representation of Interactions and Locations of the Various Proteins within the Plant Cell Involved in the Ethylene Signal Transduction Cascade

Ethylene gas diffuses freely throughout the plant cell (Bleeker and Kende, 2000). When ethylene binds to an ethylene receptor, located in the endoplasmic reticulum (Chen et al., 2002), it is inactivated and therefore, it cannot activate CTR1 (Bleeker and Kende, 2000). It is postulated that a MAP kinase cascade then follows (Guo and Ecker, 2004), culminating in the activation of transcription factors, EIN3 and ERF1 leading to the regulation of ethylene-controlled gene regulation (Guo and Ecker, 2004). Note that in the article by Chen et al. (2000), it localized the ETR1 ethylene receptor to the endoplamic reticulum. This ethylene receptor diagram presumes that the other ethylene receptors are also localized to the endoplasmic reticulum. PM, plasma membrane; ER, endoplasmic reticulum; $\mathrm{N}$, nucleus. 


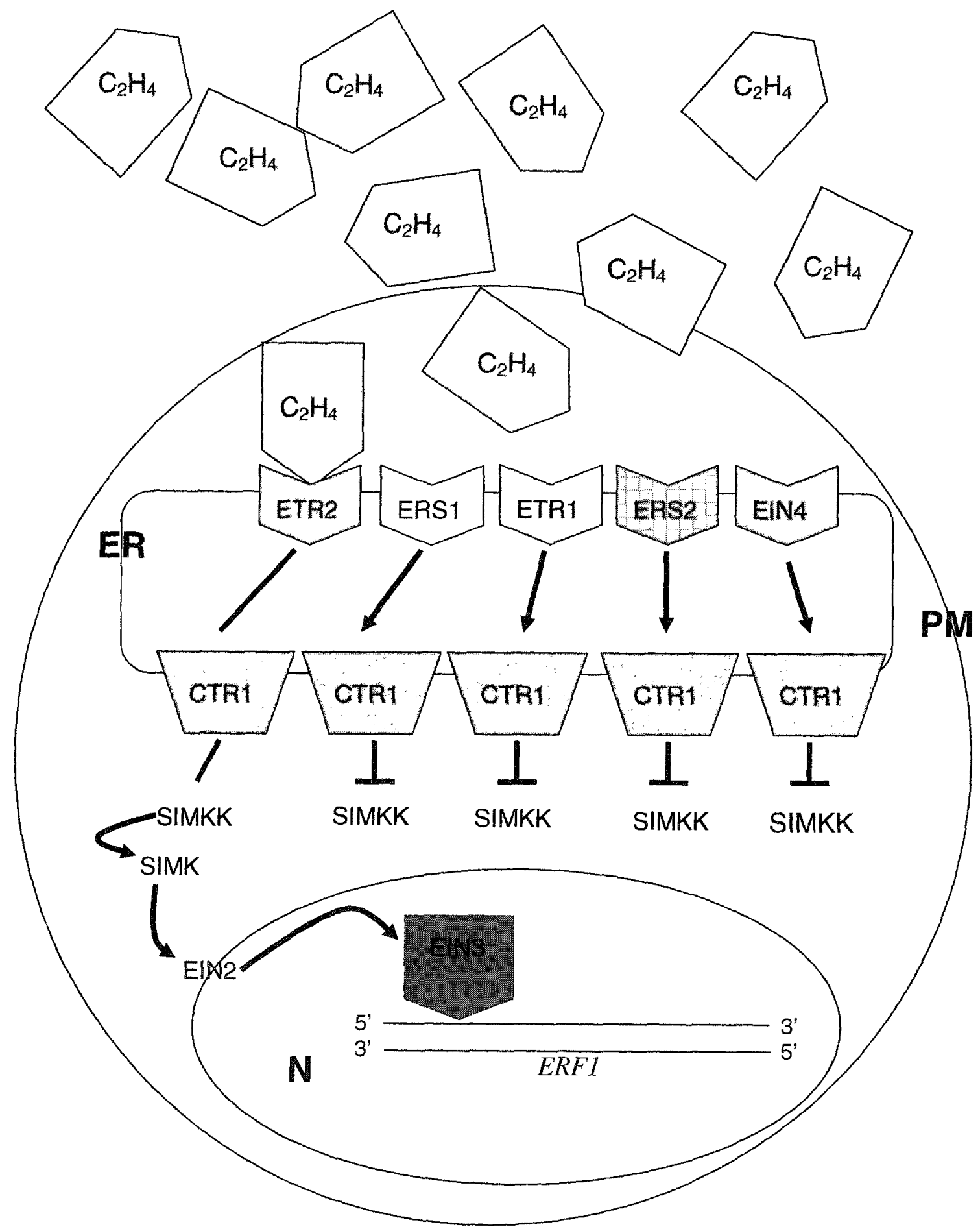

(Adapted from Ouaked et al., 2003; Stearns and Glick, 2003; Chen et al., 2002; Guo and Ecker, 2004 and Hwang et al., 2002; Alonso et al., 2003) 
The elimination of ethylene receptors activates ethylene responses. Thus, ethylene receptors repress the ethylene responses when ethylene is not present. Binding of ethylene inactivates receptor signaling (Gamble et al., 2002). Single loss-of-function mutations have little effect on ethylene signaling. This indicates that there is partial redundancy among the ethylene receptors (Gamble et al., 2002). Triple loss-of-function mutants of ETR1, ETR2 and EIN4 had a strong ethylene response. However, as the ethylene concentration was increased, the triple mutants showed reduced hypocotyl elongation. This was not evident in the ctr1 mutants. This indicates that the triple mutants were still able to respond to applied ethylene (Hua and Meyerowitz, 1998). Quadruple loss-of-function mutants had an even more severe ethylene response phenotype than the triple mutants (Hua and Meyerowitz, 1998).

Some dominant, gain-of-function mutations have also been observed which appear to lock the receptors into an active signaling state because, in the presence or absence of ethylene, ethylene responses are repressed (Gamble et al., 2002).

\subsection{Ethylene Receptors, their Domains and Requirements for Signaling within Arabidopsis}

The ETR1 ethylene receptor was the first one to be cloned by Chang et al. (1993). The existence of four other ethylene receptors was discovered 
when the ETR1 gene was hybridized to Arabidopsis genomic DNA blots and a number of other fragments were detected (Chang et al., 1993).

The amino-terminal, ethylene binding domains of all of the ethylene receptors have an electron-rich, hydrophobic pocket, formed by hydrophobic, membrane-spanning alpha helices coordinated by a copper (I) co-factor that interacts directly with ethylene (Bleeker and Kende, 2000). The copper cofactor is coordinated by two conserved amino acids, cysteine 65 and histidine 69 , both of which are present in the second transmembrane domain (Chen et al., 2002).

The responsive-to-agonist 1 (RAN1) protein is required for the biogenesis of the ethylene receptors in Arabidopsis (Stearns and Glick, 2003). It is a putative copper-transporting P-type ATPase that supplies copper ions to the receptors (Stepanova and Ecker, 2000). The constitutive triple response phenotype is observed in a ran1-3 mutant, which eliminates the copper transporter that is required for the delivery of a copper cofactor to the ethylene receptors. Thus, without the copper ion, the receptor appears to remain in a signaling-inactive state (Zhoa et al., 2002). However, the etr1-1 mutation results from an amino acid substitution at position 65 from cysteine to tyrosine. This mutation prevents copper from binding, while at the same time, locking the receptor into a signaling-active conformation, such as would be found in the absence of ethylene (Zhoa et al., 2002).

Two ETR1 monomers form a cross-linked homodimer (Schaller et al., 1995). Reducing agents are able to break this dimer apart, indicating a 
disulfide linkage between cysteine residues (Schaller et al., 1995). Cysteine4 and cysteine-6, at the amino terminus of the protein mediate this linkage. These two cysteine residues are conserved in all five ethylene receptors (Hall et al., 2000). Each dimer that is formed contains a single ethylene-binding site (Chen et al., 2002).

It has been confirmed that ethylene binds to both ERS1 and ETR1 (Hall et al., 2000), however, it remains to be determined if ethylene binds to ETR2, ERS2 and EIN4 (Hwang et al., 2002). Both Ethylene receptors, ERS1 and ETR1 belong to the ETR1-like subfamily. They have three, hydrophobic, membrane-spanning subdomains at the amino-terminus where ethylene binding occurs. They also have a conserved histidine kinase domain at the carboxy-terminus, which is located within the cytoplasm (Wang et al., 2002). ETR1 is comprised of six introns with a total of 738 amino acids (Chang et al., 1993). On the other hand, ERS1 has 613 amino acids (Hua et al., 1995) made up of five introns (Hua et al., 1995). Overall, the ERS1 protein shows 67 percent identity with the ETR1 protein (Hua et al., 1995). The putative histidine kinase domain of ERS1 is 58 percent identical to that of ETR1 (Hua et al., 1995). Also, the amino-terminal domain of ERS1, making up amino acid residues one through 321 , is 75 percent identical to that of ETR1, with no significant similarity to any other sequences (Hua et al., 1995) Both ERS1 and ETR1 have the five conserved amino acids that are found in histidine protein kinases (Hua et al., 1995). 
ETR1 and ERS1 belong to subfamily I of the ethylene receptor family since only these receptors have conserved histidine kinase domains. ERS2, ETR2 and EIN4 are classified as members of subfamily II because they do not possess a conserved histidine kinase domain. If the transmission of the ethylene signal occurs through a two-component phosphotransfer mechanism, then ETR1 and ERS1 should perform a special function (Wang et al., 2003). This has been confirmed by demonstrating that subfamily 1 receptors can perform ethylene signaling throughout the plant in the absence of subfamily II receptors (Hall and Bleeker, 2003). In the absence of subfamily I receptors, subfamily II receptors are capable of signaling in etiolated hypocotyls and roots (Hall and Bleeker, 2003). On the other hand, when subfamily I receptors are non-functional such as in the ers 1-2, etr1-7 double loss-of-function mutant, increased expression of subfamily II receptors could not compensate for their severe constitutive response phenotype (Hall and Bleeker, 2003) The ers1-2, etr1-7 double mutant phenotype is very similar to the light-grown phenotype of the ran 1-4 mutant, a loss-of-function mutant with defects in copper transport that is thought to render all ethylene receptors non-functional (Hall and Bleeker, 2003). As well, this double loss-of-function mutant demonstrates a strong constitutive ethylene response, comparable to the etr1;etr2;ein4;ers2 quadruple loss of function mutant (Guo and Ecker, 2004). These results suggest that there is a very important role for the subfamily I receptors in ethylene signaling (Hall and Bleeker, 2003). 
There is evidence of a direct interaction between the transmitter domains of both ERS1 and ETR1 receptors and the regulatory domain of the Raf-like CTR1 protein, believed to be the next protein involved in the ethylene signal transduction pathway (Hall and Bleeker, 2003). While ETR1 and ERS1 have a high binding affinity for CTR1, the type II ethylene receptors have a low affinity for binding CTR1 (Guo and Ecker, 2004). Even though evidence points to the dominant roles of type I receptors in ethylene signaling, all mutant combinations maintained the ability to respond to ethylene, even if minimally (Hall and Bleeker, 2003).

The five conserved amino acids, found in the histidine kinase domains of only the ERS1 and ETR1 ethylene receptors, include: $\mathrm{H} ; \mathrm{N} ; \mathrm{G} 1 ; \mathrm{F}$ and G2. They are considered essential for enzymatic activity (Gamble et al., 2002). The conserved histidine is the site of autophosphorylation as well as a catalytic site (Gamble et al., 2002). All of the other residues make up the nucleotide binding cleft (Hwang et al., 2002). 
Figure 4. Arabidopsis thaliana Ethylene Receptor Proteins

(A) This schematic representation of ETR1, ETR2 and EIN4 illustrates that these three proteins possess a putative receiver domain at their carboxy terminus (Stepanova and Ecker, 2000).

(B) Both ERS1 and ERS2 lack this putative receiver domain at their carboxy terminus (Gamble et al., 2002), however, all 5 proteins possess a putative ethylene binding, transmembrane domain at their amino terminus, as well as a GAF domain of unknown function (Stearns and Glick, 2003). Only ETR1 and ERS1 are believed to have functional histidine kinase domains because they possess the five amino acids believed to be necessary for histidine kinase activity (Guo and Ecker, 2004). H, histidine; N, asparagine; G, glycine; F, phenlyalanine; D, aspartic acid. 
A Amino terminus Carboxy terminus

ETR1

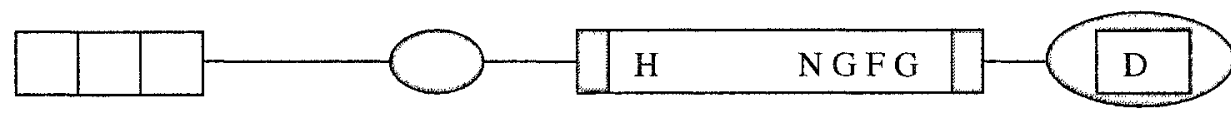

ETR2

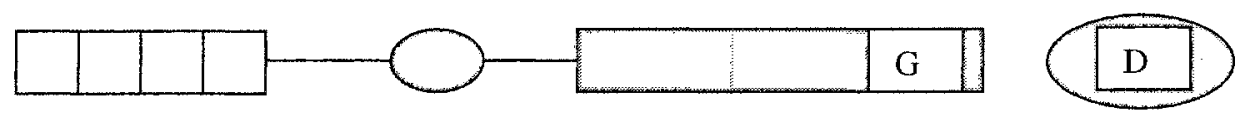

EIN4

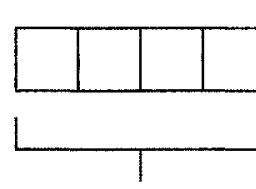

Transmembrane Domain

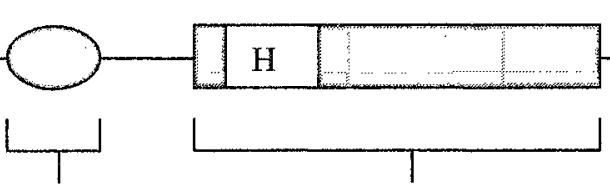

GAF Domain
Histidine Kinase Domain

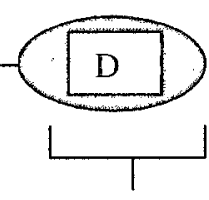

Receiver Domain

B
Amino terminus
Carboxy terminus

ERS1

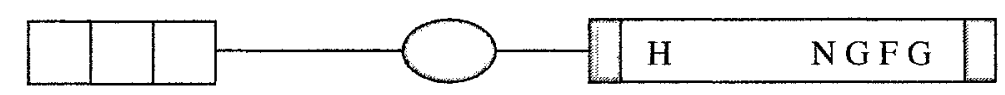

ERS2

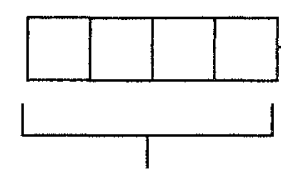

Transmembrane

Domain

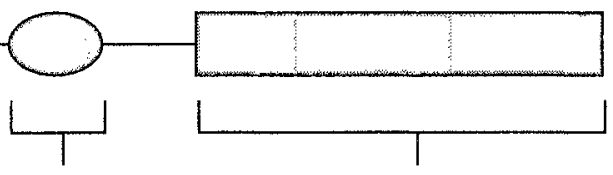

GAF

Domain
Histidine Kinase Domain

(Based on figures by Gamble et al., 2002) 
Figure 5. Autophosphorylation of ETR1

Signal transduction in the ethylene signal transduction pathway is believed to occur when there is an autophosphorylation of a histidine residue in the kinase transmitter domain. Following this event, there is a transfer of a phospate to an aspartate residue in the receiver domain of the response regulator (Wang et al., 2003). H, histidine; N, asparagine; G, glycine; F, phenlyalanine; $D$, aspartic acid; $P$, phosphate ion. 
ETR1

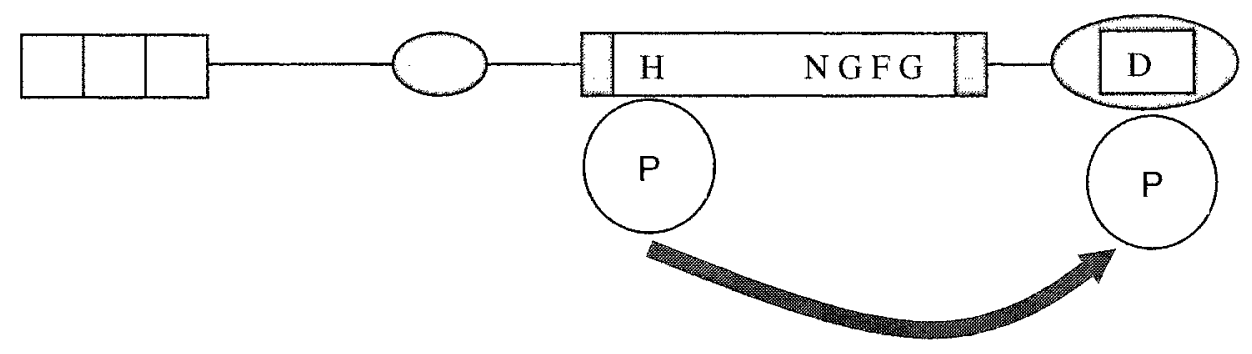

(Adapted from Hwang et al., 2002 and Imamura et al., 1990) 
Since ERS1 and ERS2 lack the receiver domain, it is suggested that they form heterodimers with either ETR1, ETR2 or EIN4 (Wang et al., 2002). It is also possible that they use other response regulators (Stepanova and Ecker, 2000). It should be noted that, in etr1;etr2;ein4, triple loss-of-function mutants, where only the ethylene receptors that lack the receiver domain are functional, some ethylene related signaling is observed (Hall and Bleeker, 2003). In this case, either the receiver is not necessary for the ethylene signal to be transduced or, a yet unknown receiver is utilized to transduce the signal.

\subsection{Ethylene Receptors as Two-Component Regulators}

In 1993, in yeast and in Arabidopsis, bacterial-type histidine kinases were first discovered (Urao et al., 2000). It was found that the carboxyterminal region of ETR1 has high sequence identity with a family of prokaryotic signal transducers known as two-component regulators. The highest identity was found within the histidine kinase and receiver domains of ETR1 (Chang et al., 1993). The two components were two separate proteins, referred to as the sensor and the response regulator. These two proteins act together in bacteria to coordinate such activities as chemotaxis, host recognition for pathogen invasion, osmoregulation, phosphate regulation, stess-induced sporulation and nitrogen regulation (Chang et al., 1993). ETR1 is referred to as a hybrid kinase because these are two separate components in bacteria, but are found together within a single protein (Chang et al., 1993). 
Figure 6. The Mechanism of Action of a Superfamily of Catalytic Receptors Found in Bacteria

The sensor protein in bacteria is composed of an amino-terminal input domain that receives a given signal, and a catalytic transmitter domain at the carboxy-terminus that autophosphorylates an internal histidine residue (Bleeker and Kende, 2000). In bacteria, the transmitter domain is a conserved histidine protein kinase found within the cytoplasm. The input domain is located in the periplasmic space, flanked by two transmembrane domains (Chang et al., 1993).

The response regulator protein is the second component of the twocomponent regulator. Bacterial response regulators have four highly conserved residues, three aspartates and a lysine. ETR1 has these motifs, except that in place of the second aspartate, there is a glutamate (Chang et al., 1993). In bacteria, the response regulator is made up of a receiver domain that receives a phosphate, on the third conserved aspartate residue, from the phosphorylated histidine within the histidine kinase domain (Bleeker and Kende, 2000). The second component, at the carboxy-terminal end of the response regulator in bacteria is the output domain. ETR1 does not have this output domain in the response regulator (Chang et al., 1993). The carboxyterminal domain of the response regulator in bacteria is often variable. In bacteria, this domain is often a DNA-binding, transcriptional activator that is activated by the phosphorylation of the aspartate residue within the receiver domain (Chang et al., 1993). 


\section{Sensor Protein}
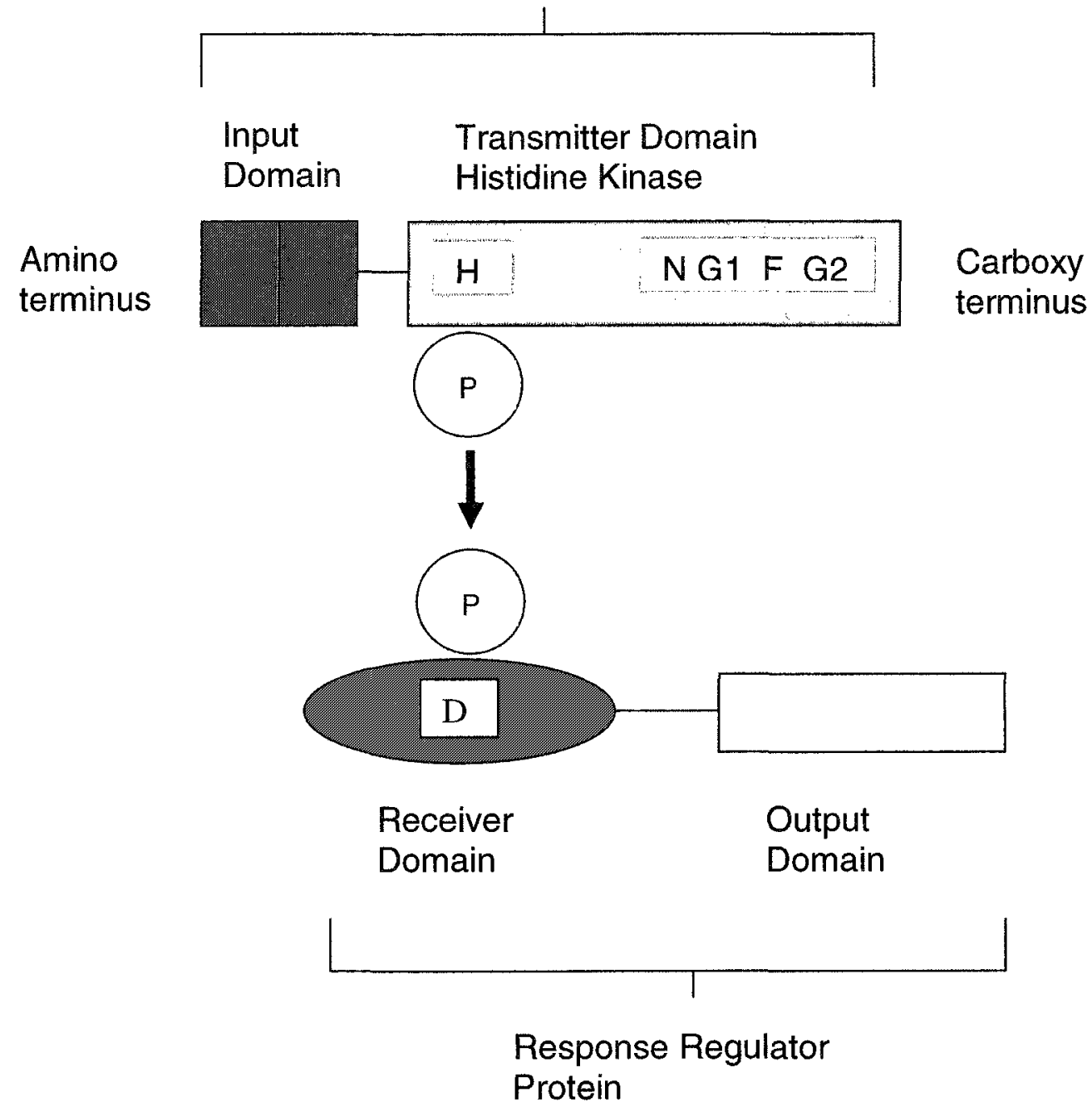

(Based on a figure by Lohrmann and Harter, 2002) 


\section{5 Other Proteins Involved in the Ethylene Signal Transduction Pathway}

Representatives of both classes of ethylene receptors also exist in other plants (Stepanova and Ecker, 2000). Therefore, it is likely that the mechanism of ethylene perception is conserved, at least in flowering plants (Stepanova and Ecker, 2000). The ethylene signal transduction pathway has features that are similar to the bacterial two-component system and to the eukaryotic MAP kinase pathways (Alonso et al., 1999). The two-component system in plants is believed to have originated from cyanobacteria. However, cyanobacteria lack the proteins that are found downstream of the twocomponent system, that is, the MAP kinase proteins. Therefore, the likely scenario for the acquisition of ethylene receptors into plants is that there was an infusion of genes through horizontal transfer from a cyanobacterial endosymbiont. The genes became altered in their activity and, subsequently, became linked to the eukaryotic, MAP kinase signal transduction pathway (The Arabidopsis Genome Initiative, 2000).

In Arabidopsis, ethylene receptors are believed to be sensor histidine protein kinases that transmit signals through a MAP kinase cascade (Hwang et al., 2002). MAP kinases are responsible for phosphorylation and are therefore, able to activate transcription factors and effector proteins (Stearns and Glick, 2003). The first protein in the MAP kinase cascade is CTR1, a Rafrelated serine/threonine kinase (Hall and Bleeker, 2003), and a putative MAP kinase kinase kinase (Stepanova and Ecker, 2000). 
Ethylene receptors may regulate the activity of CTR1

allosterically (Hall and Bleeker, 2003). Direct physical interaction has been demonstrated, when ethylene receptor proteins have been expressed in yeast as well as in vitro, between the transmitter domain of ETR1, ETR2 and ERS1 with the presumed regulatory domain of CTR1 at the amino-terminus (Hall and Bleeker, 2003). It has also been demonstrated, in vitro, that the amino terminus of CTR1 can interact with the receiver domain of ETR1 (Clark et al., 1998).

Another scenario is that the ethylene receptors regulate CTR1 enzymatically by phosphorylating it (Clark et al., 1998). Autophosphorylation of the histidine in the kinase domain of the ethylene receptors could also regulate other proteins involved in the ethylene signal transduction pathway (Gamble, 1998).

Recently, a putative MAP kinase kinase and a MAP kinase have been identified in the ethylene response pathway (Ouaked et al., 2003). In Arabidopsis, ethylene has been shown to induce the activation of the MAP kinase, MPK6, an ortholog of Medicago SIMK protein (Ouaked et al., 2003). Functional ethylene receptors and a functional CTR1 protein are required for the ACC induced activation of MPK6. Therefore, it is likely that the MAP kinase cascade in the ethylene response pathway in Arabidopsis consists of SIMKK and SIMK (MPK6), which act downstream of CTR1 (Ouaked et al., 2003). 
It is thought that SIMKK in Arabidopsis, is a positive regulator of the ethylene response because, when it was over expressed, it induced the constitutive ethylene response (Ouaked et al., 2003). This phenotype was not inhibited by the ethylene biosynthesis inhibitor, aminoethoxyvinylglycine. Therefore, it is likely that the ethylene response that was exhibited was due to increased ethylene pathway signaling, rather than ethylene overproduction (Ouaked et al., 2003). Consequently, CTR1 acts as a negative regulator of SIMKK and SIMK (MPK6) in this pathway (Ouaked et al., 2003).

\subsection{The Role of the Histidine Kinase Domain in Ethylene Receptors}

The transformation of wild-type Arabidopsis thaliana with the promoter and coding region of etr $1-1$ yields transformants that are ethylene insensitive (Gamble et al., 2002). However, it was recently discovered that inactivated histidine kinase, as well as truncated versions of etr1-1, lacking the histidine kinase and receiver domains, would also confer ethylene insensitivity when transformed into wild-type plants (Gamble et al., 2002). Therefore, the histidine kinase domain is not required to elicit the ethylene insensitive phenotype produced by etr1-1 (Gamble et al., 2002). It is possible that these histidine kinase deficient receptors form dimers with wild-type ethylene receptors and are therefore capable of signal output (Gamble et al., 2002).

Another recent experiment performed by Wang et al., (2003) also suggested that the histidine kinase domains on the ethylene receptors are not needed for the transmission of the signal from the receptor to downstream 
effectors in the ethylene signal transduction pathway. In this experiment, a severe loss of function double mutant, ers 1-2; etr1-7, that was deficient in histidine kinase receptor isoforms, was transformed individually with the CDNA's of all five receptor isoforms, under the control of the ETR1 promoter. The expression of the cDNA of either ERS1 or ETR1 restored the loss of function phenotype in this double mutant, while none of the cDNA's of ETR2, ERS2 nor EIN4 changed the phenotype (Wang et al., 2003). Similarly, a mutated allele of ETR1, lacking a functional histidine kinase domain, was transformed into these double mutants and was able to restore the severe loss of function phenotype (Wang et al., 2003). This suggests that the loss of function phenotype is not due to the lack of the histidine kinase activity. However, since only the transgenic expression of ERS1 and ETR1, and not ERS2, ETR2 or EIN4, was able to rescue the severe loss of function phenotype of this double mutant, it suggests that these type 1 receptors have a unique role in ethylene signaling (Guo and Ecker, 2004).

\subsection{Arabidopsis Seeds, Seed Dormancy and Seed Germination}

The anatomy of any seed is extremely important for the survival of a given species. The seed allows the enclosed embryo to survive the period between seed maturation and seedling establishment (Koornneef et al., 2002).

Seed dormancy is the temporary failure of an intact viable seed to germinate under favourable conditions (Leon-Kloosterziel et al., 1996). The 
establishment of seed dormancy in higher plants is influenced by environmental cues such as moisture, light, temperature and duration of seed storage (after-ripening) (Steber and McCourt, 2001). Dormancy typically demonstrates reduced metabolic activity, thus allowing a seed to survive in its environment for extended periods of time (Dubreucq et al., 1996).

Primary dormancy develops during seed formation on the mother plant during the late stages of seed development (Beaudoin et al., 2000). It can be relieved by dry storage, or by imbibation at certain temperatures over a certain duration (Matilla, 2000) or by treatment with gibberellin (Debeaujon and Koornneef, 2000). Mature Arabidopsis seeds show primary dormancy when freshly released from the mother plant and the seeds must experience these dormancy-breaking measures in order to germinate (Debeaujon et al., 2000). For example, freshly harvested seeds of wild-type strains of Arabidopsis plants, are dormant when tested in light but they were no longer dormant after one month of after-ripening (drying) (Debeaujon et al., 2000). If primary dormancy is present before seed dissemination, then secondary dormancy is that dormancy that is established after dissemination (Dubreucq et al., 1996).

The purpose of seed dormancy is to prevent germination during periods that are unfavourable to plant growth (Matilla, 2000). Since plants are non motile, the choice between continued dormancy and germination of the seed is crucial for the plant's survival (Steber and McCourt, 2001). In the natural setting, wild-type Arabidopsis thaliana seeds exhibit seed dormancy. 
This allows the seeds that are in the dormant state to survive the dry summer period and then, to subsequently, germinate during the moist, cool conditions of autumn, when the environment is more favourable for growth (LeonKloosterziel et al., 1996).

Dormancy and germination are determined by the co-action of the growth potential of the embryo and the restraints imposed by the surrounding tissues (Koorneef et al., 2002). Present both among accessions of wild plants and among varieties of cultivated plants, is genetic variation for seed dormancy (Koorneef et al., 2002). As well, some mutants have been described as having reduced seed dormancy as a result of their embryo phenotypes (Leon-Kloosterziel et al., 1996). After-ripening is normally required during seed development. The ability to germinate as freshly harvested seeds indicates a lack of this requirement (Leon-Kloosterziel et al., 1996).

Treatments to break dormancy in wild-type Arabidopsis seeds include: after-ripening; chilling; scarification or gibberellin treatment (Dubreucq et al., 1996). Arabidopsis seeds that have matured under dry conditions for a month do not require a chilling period to germinate (Ghassemian et al., 2000). When dormancy has been broken in a seed and it is not allowed to germinate, due to unfavourable conditions, it is susceptible to loss of viability (Dubreucq et al., 1996).

Germination involves a series of metabolic processes, regulated by hormones (Matilla, 2000). It begins with the uptake of water by the dry seed 
and it also includes the revival and elongation of the embryonic axis (Debeaujon et al., 2000). The embryonic axis may contain the true target cells for certain phytohormones (Matilla, 2000). The most visible feature of germination is the protrusion of the radicle tip through the seed envelopes (Debeaujon et al., 2000).

\subsection{Plant Hormones and Their Effect on Seed Dormancy and Germination}

Even though many seeds produce ethylene during germination, ethylene's role in the germination process is not certain (Matilla, 2000). Ethylene gas is produced during seed imbibation and it was proposed that this gas was needed to break seed dormancy in some species (Matilla, 2000). Some mutant seeds require the application of exogenous ethylene to germinate. However, little is known about the action mechanism (Matilla, 2000).

Another hormone, abscisic acid (ABA) blocks precocious seed germination by regulating the expression of specific genes during seed development that help to establish seed dormancy (Dubreucq et al., 1996). Recent experiments have demonstrated that maintaining dormancy in imbibed seeds requires ongoing ABA synthesis (Beaudoin et al., 2000). As further evidence, era1, an ABA supersensitive mutant, displays enhanced seed dormancy (Ghassemain et al., 2000) while ABA-insensitive mutants, $a b i 1, a b i 2$ and abi3 show reduced seed dormancy. Additionally, the ABA 
deficient mutant, $a b a$, is one of the most non-dormant mutants (LeonKloosterziel et al., 1996).

Ethylene seems to act antagonistically to ABA during seed development, since ethylene insensitive mutations in Arabidopsis increase the sensitivity of the seeds to ABA (Ghassemian et al., 2000). Ethylene is a negative regulator of $A B A$, thus promoting germination (Ghassemian et al., 2000).

Gibberellic Acid (GA) is needed during imbibation to break ABA induced dormancy (McCourt, 1999) in order to trigger germination (Beaudoin et al., 2000). GA is required for the germination of wild-type plants, since GA deficient mutants, such as ga1, will not germinate (Beaudoin et al., 2000). Conversely, GA deficient and ABA deficient, double mutants will germinate (Beaudoin et al., 2000). Therefore, there appears to be an antagonistic relationship between GA and ABA (Debeaujon and Koornneef, 2000).

\subsection{Research Objectives and Experimental Hypothesis}

The etr1-1, gain-of-function mutant seeds experience difficulty in germinating (Ecker, 1995). In this project, a chimeric gene was constructed, whereby the transmembrane and GAF encoding domains of the ETR1 gene were attached to the histidine-kinase encoding domain of the ERS1 gene. Site-directed mutagenesis was then performed on this construct to imitate the cysteine to tyrosine mutation at amino acid 65 in the etr1-1 mutant. This construct was then transformed into wild-type Arabidopsis plants. Since this 
construct has a transmembrane encoding domain that mimics that of the etr11 mutant allele and it contains the histidine kinase encoding domain of ERS1, without a response regulator encoding domain, the dormancy of the seeds from this transformant should not be affected. The hypothesis of this experiment is that these seeds will germinate normally, thus imitating the phenotype of a wild-type plant. If this is true, it suggests that the histidine kinase domain of ERS1 will not transmit the signal to downstream regulators because it is lacking the response regulator domain that is found at the carboxy-terminal end of ETR1. 


\section{Materials and Methods}

\subsection{Isolation of RNA from Arabidopsis}

The QIAGEN RNeasy Kit was used to isolate total RNA from entire Arabidopsis plants (Columbia accession). Approximately, $100 \mathrm{mg}$ of tissue was obtained when the plant was crushed into a fine powder by means of a mortar and pestle while, simultaneously, being immersed in liquid nitrogen. This frozen tissue was then, immediately, transferred to a $1.5 \mathrm{ml}$ centrifuge tube that contained $450 \mathrm{ul}$ of RLT Buffer (lysis buffer). It was crucial that the plant tissue was not allowed to thaw. Once the tissue was added to the buffer, the mixture was gently vortexed. The remaining steps were followed according to the manufacturer's instructions. The final product, containing total RNA was stored at $-80^{\circ} \mathrm{C}$.

\subsection{Synthesizing First-Strand cDNA}

Arabidopsis total RNA was used to create first strand complementary DNA (CDNA). Into a new $1.5 \mathrm{ml}$ microtube, the following items were added: 5 ul 5X First Strand Buffer (250 mM Tris- $\mathrm{HCl}, \mathrm{pH} 8.3,375 \mathrm{mM} \mathrm{KCl,} 15 \mathrm{mM}$ $\mathrm{MgCl}_{2}, 50 \mathrm{mM} \mathrm{DTT}$ ), 1 ul of RNase inhibitor (40 Units) (USB), $1 \mathrm{uL}$ (50 nM) oligo dT primers (Life Technology), 2 ul (20nM) dNTPs (Life Technology), 2 $\mathrm{uL}(40 \mathrm{U})$ of reverse transcriptase (USB) and finally, $20 \mathrm{uL}$ (8ug) of total RNA. The mixture was incubated at $37^{\circ} \mathrm{C}$ for one hour and was then stored at $20^{\circ} \mathrm{C}$. 


\subsection{Designing Primers}

\subsubsection{Primers for Cloning}

Based on the known sequences of the ETR1 and ERS1 ethylene receptors that could be found at the NCBI (National Centre for Biotechnology Information) site, primers were designed for the specific regions of these genes that needed to be obtained. Forward and reverse primers were designed to obtain the following DNA fragments:

1) The transmembrane and GAF encoding regions of ETR1

2) The transmembrane and GAF encoding regions of ERS1

3) The histidine kinase and response regulator encoding regions of ETR1

4) The histidine kinase encoding region of ERS1

For the transmembrane and GAF encoding regions of ETR1 and ERS1, the Nco1 restriction site was added to the 5' ends of both of the forward primers and the Apa1 restriction site was added to the 5' ends of both of these reverse primers (Table 2). For the histidine kinase and response regulator encoding regions of ETR1 and for the histidine kinase encoding region of ERS1, the Apa1 restriction site was added to the 5' ends of both of these forward primers and the BstEll restriction site was added to the 5 ' ends of both of these reverse primers (Table 2). Primer synthesis was carried out by Invitrogen.

\subsubsection{Primers for Confirming that the Inserts are in the Vector}


To confirm that the inserts were correctly oriented in the pCambia 1301 vector and that they were not inserted as concatamers, forward and reverse primers, named ConfirmETR1-fr and ConfirmETR1-rv, were designed (Table 2). They were based on the nucleotide sequence within the pCambia 1301 vector near the 3' end of the inserted fragment and near the 5' end of the inserted fragment.

\subsubsection{Primers for Performing Site-Directed Mutagenesis}

Once the chimeric DNA composed of the transmembrane domain of ETR1 and the histidine kinase domain of ERS1 was ligated into the pCambia 1301 vector, site-directed mutagenesis was performed to introduce a mutation into the transmembrane domain of ETR1. The primers that were used to introduce the base pair change into the pCambia 1301 plasmid containing the inserts were SDMETR1-fr and SDMETR1-rv (Table 2). 
Table 2. Primers Used in this Project

\begin{tabular}{|c|c|c|}
\hline Primer Name & Purpose & Sequence in $5^{\prime}$ to $3^{\prime}$ Direction \\
\hline TMGETR1-fr & $\begin{array}{l}\text { To obtain } \\
\text { TMGETR1 } \\
\text { fragment }\end{array}$ & $\begin{array}{l}\text { CCA TGG CGC TCC CCT TTT CTC CTT } \\
\text { CTC CGT CGC TCT CCG C }\end{array}$ \\
\hline TMGETR1-rV & $\begin{array}{l}\text { To obtain } \\
\text { TMGETR1 } \\
\text { fragment }\end{array}$ & $\begin{array}{l}\text { GGG CCC CTC CAT GAG AAG GTC CCT } \\
\text { AGC TCG CAT CGA }\end{array}$ \\
\hline TMGERS $1-f r$ & $\begin{array}{l}\text { To obtain } \\
\text { TMGERS1 } \\
\text { fragment }\end{array}$ & $\begin{array}{l}\text { CCA TGG CCC AAA GCT ATG AGG CTC } \\
\text { ACA CCA CC }\end{array}$ \\
\hline TMGERS1-rv & $\begin{array}{l}\text { To obtain } \\
\text { TMGERS1 } \\
\text { fragment }\end{array}$ & $\begin{array}{l}\text { GGG CCC CTC CAT AAG CTG GTC ACG } \\
\text { AGC GTG CAT GGA }\end{array}$ \\
\hline HKETR1-fr & $\begin{array}{l}\text { To obtain } \\
\text { HKETR1 } \\
\text { fragment }\end{array}$ & $\begin{array}{l}\text { GGG CCC CAG AAT GTT GCT CTT GAT } \\
\text { CTA GCT AGA CGA GAA G }\end{array}$ \\
\hline HKETR1-rV & $\begin{array}{l}\text { To obtain } \\
\text { HKETR1 } \\
\text { fragment }\end{array}$ & $\begin{array}{l}\text { GGT GAC CTT ACA TGC CCT CGT ACA } \\
\text { GTA CCC GGG GCT C }\end{array}$ \\
\hline HKERS1-fr & $\begin{array}{l}\text { To obtain } \\
\text { HKERS1 } \\
\text { fragment }\end{array}$ & $\begin{array}{l}\text { GGG CCC CAG AAT TTT GCT TTA GAC } \\
\text { AAG GCT CGT CAA GAG GC }\end{array}$ \\
\hline HKERS1-rV & $\begin{array}{l}\text { To obtain } \\
\text { ERS1 } \\
\text { fragment }\end{array}$ & $\begin{array}{l}\text { GGT GAC CCC AAT AAG TTA GAT CAC } \\
\text { ACC GTC CGG TCA TG }\end{array}$ \\
\hline SDMETR1-fr & $\begin{array}{l}\text { To create a } \\
\text { point mutation }\end{array}$ & $\begin{array}{l}\text { GGG TAC TTG TTC AGT TTG GTG CTT } \\
\text { TTA TCG TTC TTT TG GAG CAA CTC }\end{array}$ \\
\hline SDMETR1-rV & $\begin{array}{l}\text { To create a } \\
\text { point mutation }\end{array}$ & $\begin{array}{l}\text { GAG TTG CTC CA AAA GAA CGA TAA } \\
\text { AAG CAC CAA ACT GAA CAA GTA CCC }\end{array}$ \\
\hline ConfirmETR1-fr & $\begin{array}{l}\text { Confirm } \\
\text { TMGETR } 1 \text { in } \\
\text { pCambia } 1301\end{array}$ & CCT AAC AGA ACT CGC CGT AAG AC \\
\hline ConfirmERS1-rv & $\begin{array}{l}\text { To confirm } \\
\text { HKERS1 is in } \\
\text { pCambia } 1301\end{array}$ & $\begin{array}{l}\text { GGA CTC TAA TCA TAA AAA CCC ATC } \\
\text { TC }\end{array}$ \\
\hline
\end{tabular}

Note: The restriction sites are underlined. The BstEll restriction site sequence is GGTGACC, the Ncol restrictions site sequence is CCATGG and the Apal restriction sequence is GGGCCC. In the SDMETR1 forward and reverse primers, the base pair change that was made to introduce the mutation is highlighted in red. 
Figure 7. Diagram of Primer Locations in ETR1 and ERS1 Genes (A) The TMGETR1 fragment, 1103bp long, was obtained through using a forward primer that was located in the 5' untranslated region of ETR1. The reverse primer began at the end of the region that coded for the GAF domain. The HKETR1 fragment, that was $1219 \mathrm{bp}$ long, was obtained using a forward primer that began at the beginning of the histidine kinase domain and a reverse primer that began at the end of the histidine kinase domain.

(B) The TMGERS1 fragment, 1060bp long, was obtained through using a forward primer that was located in the 5' untranslated region of ERS1. The reverse primer began at the end of the region that coded for the GAF domain. The HKETR1 fragment, that was $971 \mathrm{bp}$ long, was obtained using a forward primer that began at the beginning of the histidine kinase domain and a reverse primer that began at the end of the histidine kinase domain. 

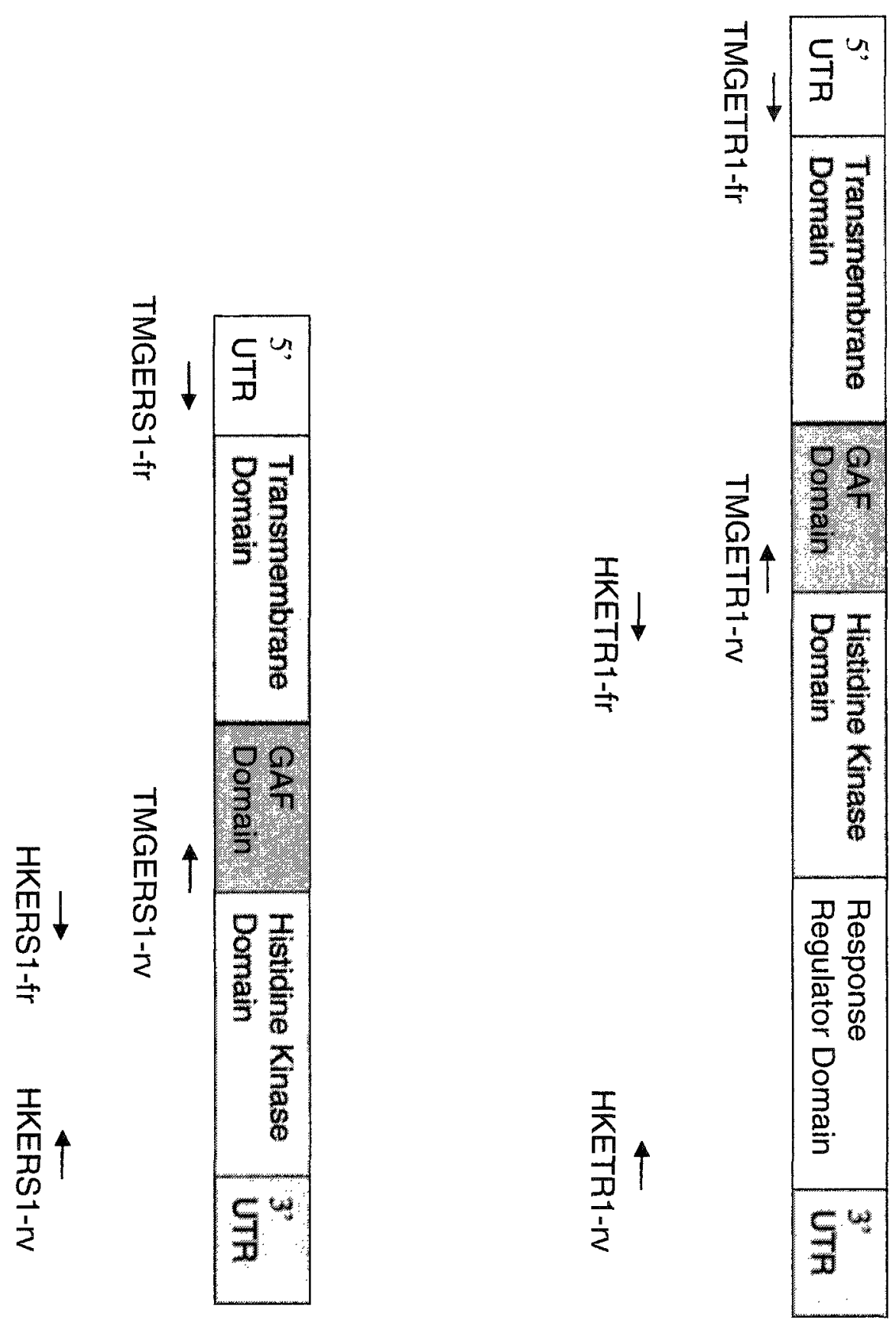


\subsection{Amplifying DNA Fragments by Means of RT-PCR}

PCR was used to amplify the fragments that were used to generate chimeric DNA. The cDNA that was produced from total Arabidopsis RNA was used as the template in these PCR reactions. The appropriate primers were used to amplify the following fragments:

The transmembrane and GAF encoding regions of ETR1; the transmembrane and GAF encoding regions of ERS1; the histidine kinase and response regulator encoding regions of ETR1, and; the histidine kinase encoding region of ERS1.

For each reaction, the total volume of the PCR mixture was 20 ul, comprised of 2 ul of 10X High Fidelity PCR Buffer, 0.4 ul of $10 \mathrm{mM}$ dNTP's, 0.6 ul of 50 $\mathrm{mM} \mathrm{MgSO}_{4}, 1 \mathrm{ul}$ of forward primer and $1 \mathrm{ul}$ of reverse primer, each at a concentration of $10 \mathrm{mM}, 0.4 \mathrm{ul}$ of $5 \mathrm{U} / \mathrm{ul}$ Platinum Taq DNA Polymerase High Fidelity, 4 ul of cDNA template, and 10.6 ul of sterile distilled water. The PCR temperature cycler had a denaturation period of 30 seconds at a temperature of $94^{\circ} \mathrm{C}$. It had an annealing temperature of $55^{\circ} \mathrm{C}$ for a period of 30 seconds. The elongation period lasted for two minutes (this was the same for each fragment that was amplified) at a temperature of $68^{\circ} \mathrm{C}$. The PCR cycler was programmed to repeat the amplification for 30 cycles. The individual PCR products were electrophoresed on a one percent agarose gel. They were cut from the gel, recovered from the gel slice with Gene Clean ${ }^{\mathrm{TM}}$ and stored at $80^{\circ} \mathrm{C}$. 


\subsection{Performing Agarose Gel Electrophoresis}

A one percent agarose gel, comprised of a 1X TAE buffer (2 mM $\mathrm{Na}_{2}$ EDTA. $2 \mathrm{H}_{2} \mathrm{O}, 40 \mathrm{mM}$ Tris-acetate) and 0.1 percent ethidium bromide was used to electrophorese all of the DNA and RNA samples that were obtained. Orange $\mathrm{G}$ dye (1 $\mathrm{mM}$ EDTA $(\mathrm{pH}=8), 50$ percent glycerol, orange $\mathrm{G}$ dye to colour) was added to each sample ( $1 \mathrm{ul}$ of orange $\mathrm{G}$ solution to $5 \mathrm{ul}$ of sample) before adding the sample to the gel. In order to quantify the amount of DNA in the sample, the light intensity emitted from the sample band was compared to that emitted by the $1.6 \mathrm{~kb}$ band that could be observed in the lane, where 5 ul of DNA ladder (Life Technology) was added. The DNA ladder mix was prepared by adding $90 \mathrm{ul}$ of $\mathrm{T}_{10} \mathrm{E}_{1}(\mathrm{pH}=8)$ to $20 \mathrm{ul}$ of Orange $\mathrm{G}$ loading buffer (1mM EDTA ( $\mathrm{pH}=8$ ), 50 percent glycerol, orange $\mathrm{G}$ dye to colour) and $10 \mathrm{ul}$ of concentrated DNA ladder $(1 \mathrm{ug} / \mathrm{ul})$. When $5 \mathrm{ul}$ of diluted, $1 \mathrm{~kb}$ DNA ladder is added to the lane, the $1.6 \mathrm{~kb}$ band contains approximately $42 \mathrm{ng}$ of DNA. The agarose gel was electrophoresed at 85 volts using in a Owl gel rig (Owl Separation System Model BIA, Owl Separation System Inc.). The gel bands were visualized using a Gel Doc System (Alpha Innotech).

\subsection{Purifying PCR-Amplified Fragment (Gene Clean ${ }^{\mathrm{TM}}$ )}

The DNA was purified from the agarose gel using the protocol as described by Boyle and Lew (1995). The amplified PCR product was separated on a one percent agarose gel, run at 85 volts for approximately 50 minutes. The amplified DNA fragment was cut from the gel and placed into a 
pre-weighed, $1.5 \mathrm{ml}$ microtube. The mass of the gel containing the amplified DNA was determined and three volumes of $6 \mathrm{~N}$ sodium iodide were added to the gel. The sample was then incubated at $50^{\circ} \mathrm{C}$ for approximately five minutes until the gel had melted. Then, $10 \mathrm{ul}$ of silica matrix suspension was added to the sample. The sample was then mixed by tapping, left on ice for five minutes and centrifuged in a microfuge at maximum speed for five seconds. The supernatant was then discarded and the pellet was resuspended in 400 ul of 'New Wash' (50 mM NaCl, $10 \mathrm{mM}$ Tris-Cl $(\mathrm{pH}=7.5)$, $2.5 \mathrm{mM}$ EDTA, 50 percent ethanol). The 'Glass Milk' was then pelleted in the microcentrifuge at maximum speed for five seconds. The resuspension of the pellet in 400 ul of 'New Wash' and then pelleting of the 'Glass Milk' was repeated two more times. After the supernatant from the third wash was removed, the tube was centrifuged again at maximum speed for 5 seconds. Any remaining liquid in the microtube was removed with a P20 pipette and the pellet was then dried for five minutes on the $65^{\circ} \mathrm{C}$ heat block. In this step, the cover of the microtube was left open and it was covered with tissue paper to evaporate any remaining ethanol. The pellet was resuspended in $10 \mathrm{ul}$ of $\mathrm{T}_{10} \mathrm{E}_{1}(\mathrm{pH}=8)$ and it was then placed on the heat block at $50^{\circ} \mathrm{C}$ to release the DNA from the silica. The sample was then placed in a centrifuge and spun at $13.4 \times 1000 \mathrm{~g}$ to pellet the silica. The supernatant containing the DNA was then removed from the microtube and was placed into a new $1.5 \mathrm{ml}$ microtube and was stored at $-80^{\circ} \mathrm{C}$. 


\subsection{Cloning Fragments into the PGEM-T Easy ${ }^{\circledR}$ Vector}

\subsubsection{Ligating PCR-Amplified Fragments into pGEM-T Easy \& Vector}

The purified PCR product was subsequently ligated into the pGEM-T Easy ${ }^{\circledR}$ Vector (Promega). This vector is able to incorporate the DNA fragments easily because it has $3^{\prime}$ poly- $T$ tail overhangs that ligate easily to the poly-A tails found on the PCR-amplified DNA fragment. The ligation reaction consisted of 5 ul of 2X Rapid Ligation Buffer (60mM Tris-HCl ( $\mathrm{Ph}=7.8), 20 \mathrm{mM} \mathrm{MgCl}, 20 \mathrm{mM} \mathrm{DTT}, 1 \mathrm{mM}$ ATP and 10 percent PEG), $1 \mathrm{ul}$ of pGEM-T Easy ${ }^{\circledR}$ Vector (50ng), 1 ul of T4 DNA ligase (3 Weiss units/ul) and 3 ul of purified PCR product. The ligation reaction was gently vortex, centrifuged for 2 seconds and then incubated at $4{ }^{\circ} \mathrm{C}$. The ligate was then stored at $-20^{\circ} \mathrm{C}$ until it was time to transform E. coli. See Figure 8 for a map of the pGEM-T Easy $®$ Vector. 
Figure 8. Strategy for Cloning the Desired Fragments of ETR1 and ERS1 This pGEM-T Easy® Vector is a $3 \mathrm{~kb}$ fragment that has a 3 ' poly-T tail overhang for easy insertion of PCR-amplified DNA fragments that contain poly-A tails (Promega). The fragments TMGETR1, TMGERS1, HKETR1 and HKERS1 were cloned individually into this vector and were, subsequently digested out for sub-cloning into pCambia 1301 (Figure is adapted from a diagram found at promega.com). 


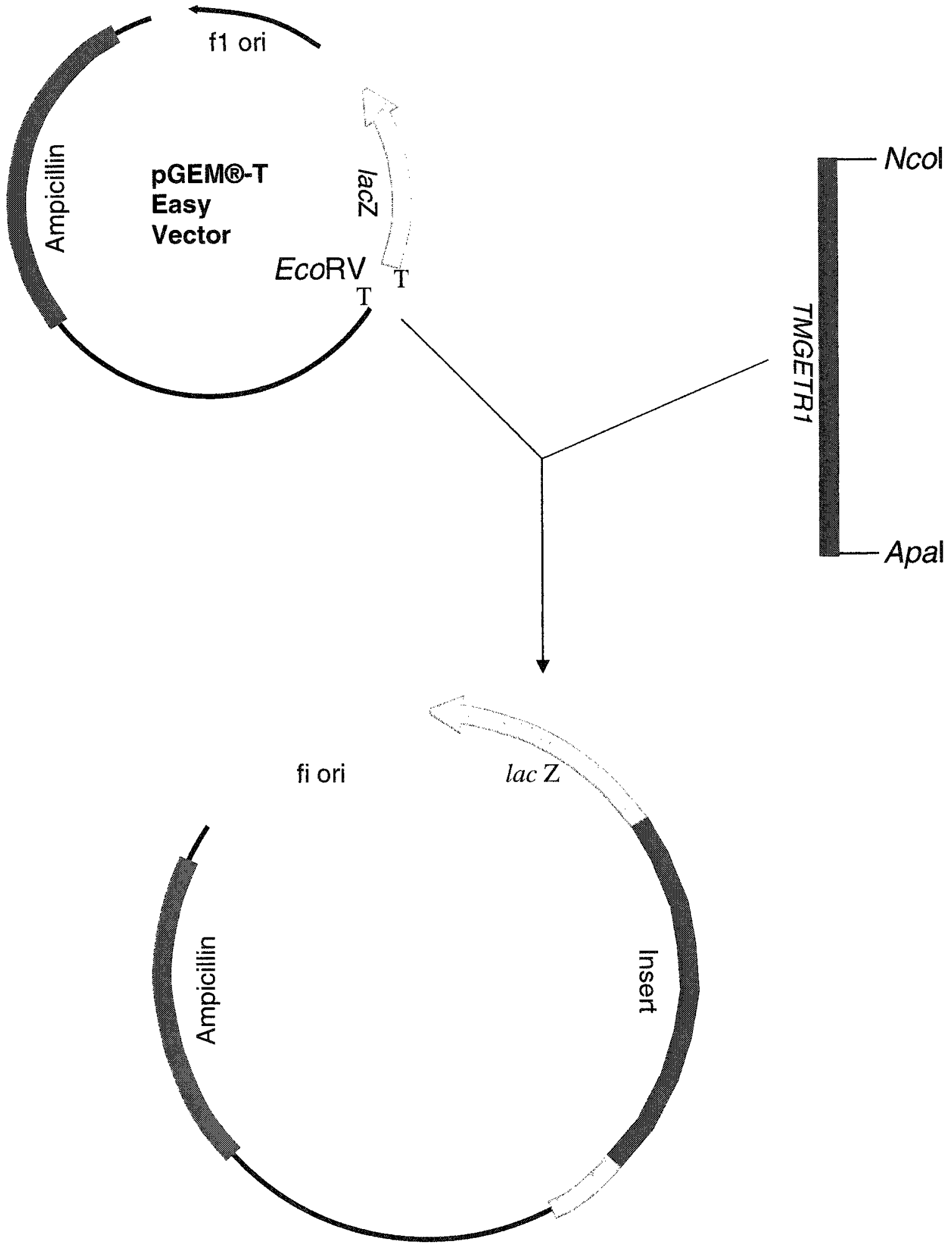




\subsubsection{Transformation of E.coli with plasmid DNA}

The transformation protocol was followed according to Sambrook et al. (2000). Approximately 40ng of plasmid DNA in 5 ul of $T_{10} E_{1}(p H=8)$ was added to 100 ul of E.coli DH5a competent cells. These cells had been previously stored at $-80^{\circ} \mathrm{C}$ and were gently thawed in an ice bucket. The mixture of plasmid DNA and competent cells was then stored in an ice bucket for 30 minutes. After 30 minutes on ice, the tube was placed in a $42{ }^{\circ} \mathrm{C}$ water bath for 90 seconds. After the 90 second water bath incubation, the tube was placed in an ice bucket for two minutes. Subsequently, 800 ul of liquid LB media was added to the plasmid/competent cell mixture and this sample was then placed in a $37^{\circ} \mathrm{C}$ shaking water bath (200rpm) for one hour. After the one hour incubation period, $200 \mathrm{ul}$ of transformed competent cells from the sample were placed on solid LB plates ( $10 \mathrm{~g}$ tryptone, $5 \mathrm{~g} \mathrm{NaCl}, 5 \mathrm{~g}$ yeast extract, 15 agar) with the appropriate antibiotic. When competent cells were transformed with the pGEM-T Easy ${ }^{\circledR}$ Vector, $100 \mathrm{ug} / \mathrm{ml}$ Ampicillin was added to the solid LB plates as well as $0.5 \mathrm{mM} \mathrm{IPTG}$ and $80 \mathrm{ug} / \mathrm{ml} \mathrm{X-Gal} \mathrm{(X-Gal} \mathrm{is}$ dissolved in dimethyl formamide). Plates were incubated for approximately 16 hours at $37^{\circ} \mathrm{C}$. Positive colonies containing the insert were white. Liquid cultures of the white colonies were made in order to perform mini-preps to obtain the recombinant plasmid. When competent cells were transformed with the pCambia 1301 vector that contained the desired insert, solid LB plates containing kanamycin $(50 \mathrm{ug} / \mathrm{ml})$ were used to screen for transformed E.coli. 


\subsubsection{Isolating Recombinant Plasmids}

\subsubsection{Bacterial Plasmid Miniprep}

A toothpick was used to scrape a single colony containing the desired plasmid. Subsequently, the toothpick with the attached bacteria was dropped into $1.5 \mathrm{ml}$ of liquid LB containing the appropriate antibiotic. After twelve hours incubation at $37^{\circ} \mathrm{C}$, the $1.5 \mathrm{ml} \mathrm{E.coli} \mathrm{culture} \mathrm{was} \mathrm{transferred} \mathrm{to} \mathrm{a} 1.5 \mathrm{ml}$ microtube and it was centrifuged at a maximum speed of $13.4 \times 1000 \mathrm{rpm}$ for five minutes. The supernatant was removed with a pipette and the cell pellet was then resuspended in $100 \mathrm{ul}$ of $\mathrm{T}_{10} \mathrm{E}_{1}(\mathrm{pH}=8)$ by gentle vortexing. Following the addition of 200 ul of $0.2 \mathrm{M} \mathrm{NaOH} / 1 \%$ SDS, the sample was mixed by tapping and incubated at room temperature for five minutes. Subsequently, 150 ul of $3 \mathrm{M}$ potassium acetate $(\mathrm{ph}=4.8)$ was added to the sample and the microtube was then vigorously mixed by vortexing for two minutes. It was then placed on ice for five minutes and then centrifuged at maximum velocity $(14.3 \times 1000 \mathrm{rpm})$ for five minutes. The supernatant was then carefully transferred to a new $1.5 \mathrm{ml}$ microtube. Then, $900 \mathrm{ul}$ of absolute ethanol was added to the supernatant. DNA was pelleted by centrifuging at $14.3 \times 1000 \mathrm{rpm}$ for two minutes, rinsed with $70 \%$ ethanol, dried in a dessicator and finally, resuspended in 20ul of TE buffer.

\subsubsection{Plasmid Isolation Using Wizard@ Plus Midipreps (Promega)}

E.coli that contain the plasmid with the desired insert were grown in $100 \mathrm{ml}$ of LB containing the appropriate antibiotic for 16 hours. The plasmid 
was then isolated according to the manufacturer's instructions. The final product was stored at $-80^{\circ} \mathrm{C}$.

\section{8}

\subsubsection{Digesting Recombinant Plasmids to obtain the TMGETR1wt and TMGERS1wt DNA Fragments}

The following DNA fragments were digested from different pGEM-T Easy ${ }^{\circledR}$ vectors using the restriction enzymes $\mathrm{Ncol}$ and Apal:

1) The transmembrane and GAF encoding regions of ETR1 (TMGETR1 wt)

2) The transmembrane and GAF encoding regions of ERS1 (TMGERS1 wt)

Both the TMGETR1 and the TMGERS1 PCR products had an Ncol restriction site at their $5^{\prime}$ end and an Apal restriction site at their $3^{\prime}$ end. Since both enzymes will operate at 100 percent efficiency in REact $₫ 4$ Buffer (20mM Tris- $\mathrm{HCl}(\mathrm{pH}=7.4), 5 \mathrm{mM} \mathrm{MgCl} 2,50 \mathrm{mM} \mathrm{KCl})$, a double digest reaction was performed to obtain both of these fragments. Into the restriction enzyme digestion reaction 15 ul of the pGEM-T Easy ${ }^{\circledR}$ vector containing the desired insert (either TMGETR1wt or TMGERS1wt) was added, along with 2 ul of Ncol enzyme, 2 ul of Apal enzyme, 5 ul of REact@ 4 Buffer, and 26 ul of distilled water. The reaction was placed on the $30^{\circ} \mathrm{C}$ heat block for two hours and then it was transferred to the $37^{\circ} \mathrm{C}$ heat block where it remained for another two hours. After the digestion reactions were complete, the entire 50 ul of the reaction mixture was electrophoresed on a $1 \%$ agarose gel. The 
desired DNA fragment was cut from the gel and purified using the Gene Clean ${ }^{\mathrm{TM}}$ procedure. The final product was stored at $-80^{\circ} \mathrm{C}$.

\subsubsection{Digesting Recombinant Plasmids to obtain the HKETR1 and HKERS1 DNA Fragments}

The following DNA fragments were digested from different pGEM-T Easy ${ }^{8}$ vectors using the restriction enzymes Apal and BstEl:

1) The histidine kinase and response regulator encoding regions of ETR1 (HKETR1)

2) The histidine kinase encoding region of ERS1 (HKERS1)

Both of the HKETR1 and the HKERS1 fragments had an Apal restriction site at their $5^{\prime}$ end and a BstEl restriction site at their $3^{\prime}$ end. Since both enzymes do not share the same restriction buffer, two, single digests had to be performed in order to obtain each of these DNA fragments. The first single digest was performed with the restriction enzyme Apal. The components of the first single digest included: 10ul of the pGEM-T Easy ${ }^{\circledR}$ vector containing the desired insert (either HKETR1 or HKERS1); 5ul of the REact@ 4 Buffer (20mM Tris- $\left.\mathrm{HCl}(\mathrm{pH}=7.4), 5 \mathrm{mM} \mathrm{MgCl}_{2}, 50 \mathrm{mM} \mathrm{KCl}\right) ; 2 u l$ of the restriction enzyme Apal, and; 13 ul of distilled water. The reaction was incubated on the $30^{\circ} \mathrm{C}$ heat block for two hours. After the digestion reaction was complete, the entire 50ul of the reaction mixture was electrophoresed on a $1 \%$ agarose gel and the desired DNA fragment was recovered as previously 
described. This DNA was then digested with the BstEll restriction enzyme and purified from the gel as described above.

\subsection{The Plant Transformation Vector - pCambia 1301}

The recombinant plasmids expressing ETR1/ERS1 constructs were isolated from E.coli(DH5a) and then used to transform Agrobacterium. The pCambia 1301 vector is 11837 base pairs in length. To prepare this vector to incorporate the chimeric DNA fragment, it was digested with the restriction enzymes, $\mathrm{Ncol}$ and BstEl. Digestion with these two restriction enzymes released a 2061base pair DNA fragment containing the GUS reporter gene that was not necessary for our purposes. Please see Figure 7 showing the map of pCambia 1301. The TDNA that eventually integrated into the Arabidopsis genome can be seen in Figure 10. Note that the expression of the chimeric DNA is driven by the CaMV 35 s promoter. 
Figure 9. A Map of the Plant Transformation Vector, pCambia 1301

This plasmid is composed of a $12 \mathrm{~kb}$ fragment. It contains a hyg $(\mathrm{R})$ cassette for plant transformation selection as well as a $\operatorname{kan}(\mathrm{R})$ cassette for bacterial selection.

(Figure is adapted from a diagram at www.cambia.org) 


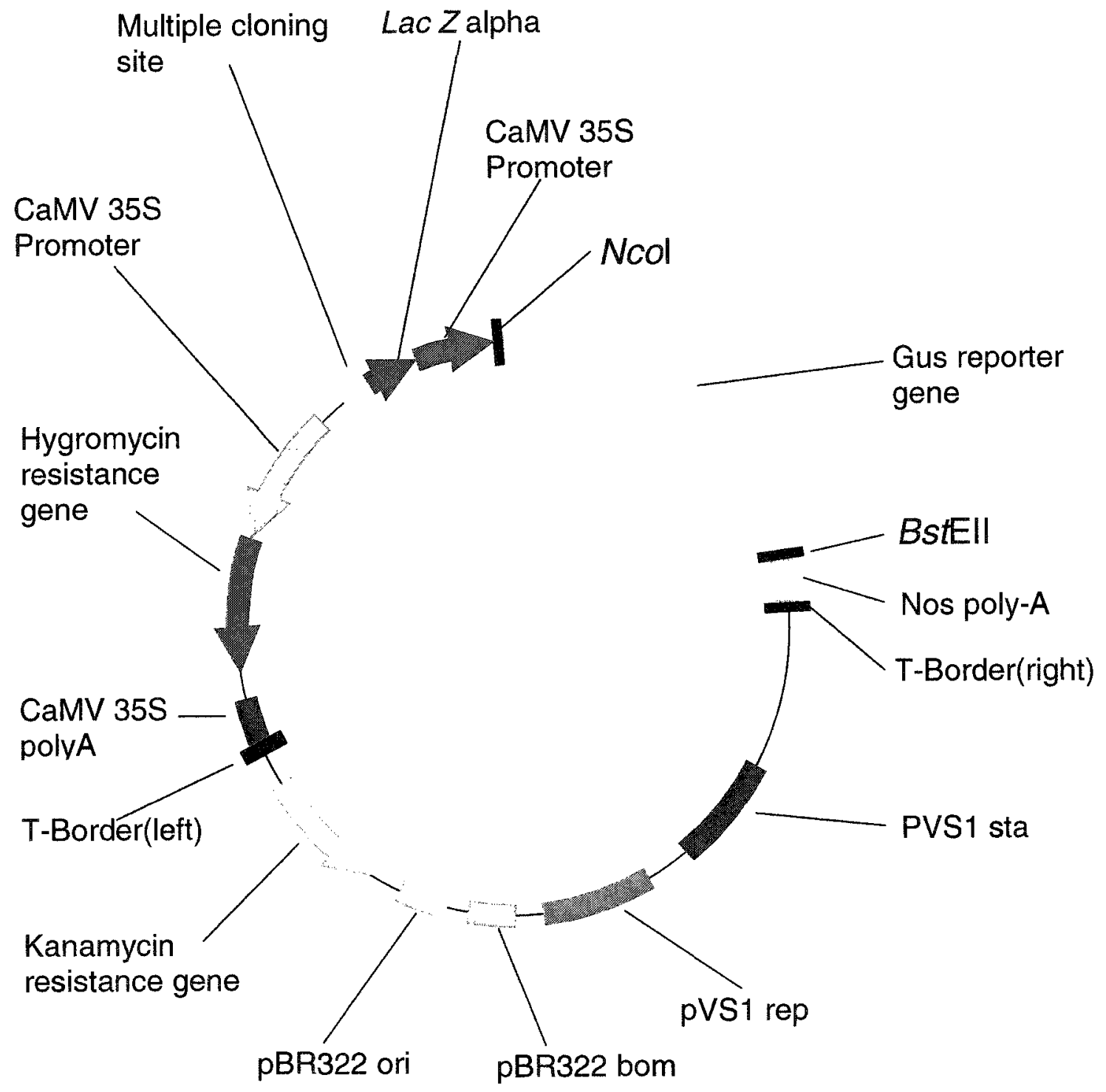

(Based on figure from cambia.org) 
Figure 10. pCambia 1301 T-DNA

This $5.6 \mathrm{~kb}$ fragment becomes inserted into the plant genome. Transformants are selected based on their resistance to hygromycin. The expression of the insertional DNA is driven by a CaMV 35 S promoter. (Figure is adapted from a diagram at www.cambia.org) 


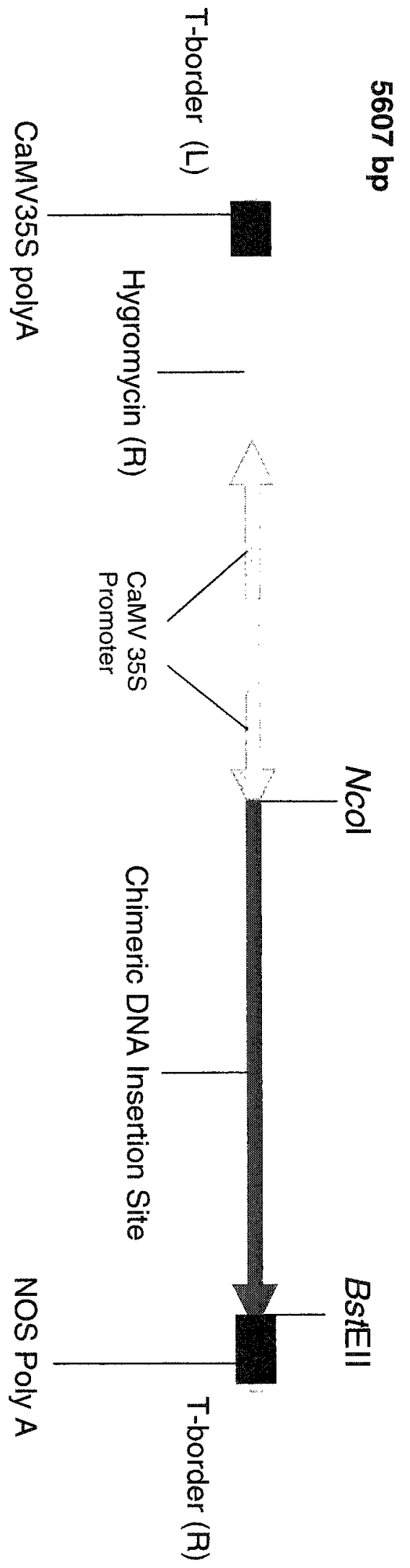

43

Reproduced with permission of the copyright owner. Further reproduction prohibited without permission. 


\subsection{Preparation of the pCambia 1301 vector for subcloning}

Even though the restriction enzymes, $\mathrm{Ncol}$ and $\mathrm{BstEII}$ share the same reaction buffer, the two digestions of the pCambia 1301 were performed separately in order to confirm that this plasmid was digested properly. The digestion products were then electrophoresed on a $1 \%$ agarose gel and the band located around the $10 \mathrm{~kb}$ region was cut from the gel. This corresponded to the pCambia 1301 vector after having been digested with both the $\mathrm{Ncol}$ and the BstEll restriction enzymes. This sample was then purified (see section 2.6) and, subsequently, stored at $-80^{\circ} \mathrm{C}$.

\subsection{Preparing Agrobacterium tumefaciens (Strain LBA4404) Competent Cells}

To prepare competent cells of A.tumefaciens, $100 \mathrm{ml}$ of LB containing $0.02 \mathrm{~g}$ of magnesium sulfate and $375 \mathrm{ul}$ of Rifampsin $(40 \mathrm{mg} / \mathrm{ml}$ concentration) in a $500 \mathrm{ml}$ Erlenmeyer flask was inoculated with a single colony of strain LBA 4404. The flask was completely wrapped with tinfoil and incubated at $28^{\circ} \mathrm{C}$ with shaking (300rpm) for approximately 48 hours until the culture attained an optical density of 0.6 at a wavelength of $610 \mathrm{~nm}$. The culture was then cooled on ice for ten minutes, and, subsequently, centrifuged at $3000 \mathrm{rpm}$ for five minutes at $4^{\circ} \mathrm{C}$. The supernatant was then poured off and the centrifuge tube was inverted on a paper towel to drain for one minute. The cell pellet was then resuspended in $1 \mathrm{ml}$ of ice cold, $20 \mathrm{mM}$ calcium chloride and dispensed into $1.5 \mathrm{ml}$ microtubes in $100 \mathrm{ul}$ aliquots. These cells were stored at $-80^{\circ} \mathrm{C}$. 


\subsection{Transforming Agrobacterium tumefaciens (Strain LBA4404) Competent Cells with the Recombinant pCambia 1301 Plasmid}

To 100ul of Agrobacterium tumefaciens (strain LBA 4404) competent cells, $5 \mathrm{ul}$ (1ug) of recombinant plasmid DNA was added in a $1.5 \mathrm{ml}$ microtube. The contents were then mixed with gentle tapping. The $1.5 \mathrm{ml}$ microtube was then dropped into a container of liquid nitrogen and it was allowed to freeze for about three minutes. The tube was then thawed on the heater block at $37^{\circ} \mathrm{C}$ for five minutes, $1 \mathrm{ml}$ of $\mathrm{LB}$ was added and the mixture was incubated on a shaker at $28^{\circ} \mathrm{C}$. The microtube containing the transformed Agrobacterium was then centrifuged at $13.4 \times 1000 \mathrm{rpm}$ for five minutes $900 \mathrm{ul}$ of the supernatant was removed. The pellet of cells was then resuspended in the remaining $100 \mathrm{ul}$ of LB. These cells were then transferred to LB plates containing rifampsin (100mg/l) and kanamycin (50mg/l) in 50ul aliquots which were incubated at $28^{\circ} \mathrm{C}$ for 48 hours.

\subsection{Sequencing of the Inserts in the Recombinant pCambia 1301 Vector}

The chimeric DNA inserts within the pCambia 1301 vector were sequenced by an automated sequencing facility (Canadian Molecular Research Services Inc. 600 Peter Morand Crescent, Suite 130, Ottawa, Ontario, K1G 5Z3). The primers for sequencing were described in section 2.3.2.

\subsection{Transforming Arabidopsis thaliana (Columbia ecotype)}


Wild type Arabidopsis thaliana ecotype Columbia plants were transformed by means of the "Floral Dip" method (Clough et al., 1998). Five or six seeds were sown in plastic containers $(3 \mathrm{~cm} \times 4 \mathrm{~cm})$ by adding a volume of approximately $100 \mathrm{ul}$ of seeds to $15 \mathrm{ml}$ of a one percent agarose solution. A glass pipette was used to extract the agarose/seed mixture and then, subsequently, used to sow the seeds on the soil. The plants were then grown at a temperature of $22^{\circ} \mathrm{C}$ with 16 hours of light and 8 hours of darkness. The plants were ready to be transformed once the plants had formed a stem that was approximately four centimetres in height and the primary inflorescences had opened and when only a few siliques and secondary inflorescences had begun to form. Two days prior to the plants being ready for transformation, $100 \mathrm{ml}$ of liquid LB media containing kanamycin at a concentration of 50 $\mathrm{mg} / \mathrm{ml}$ was inoculated with Agrobacterium tumefaciens strain LBA4404 which carried the chimeric DNA fragment in the pCambia 1301 vector. This Agrobacterium culture was grown at a temperature of $28^{\circ} \mathrm{C}$ for two days. After two days of growth, $5 \mathrm{~g}$ of sucrose and $50 \mathrm{ul}$ of Silwet L-77 were added to the 100ml Agrobacterium culture.

The wild-type Arabidopsis plants that were ready to be transformed were removed from the growth chamber and siliques that were visible on these plants were clipped off with scissors because there was not chance that these seeds would be transformed. The Agrobacterium culture containing sucrose and Silwet L-77 were then poured into a small bowl $(5 \mathrm{~cm} \times 5 \mathrm{~cm} \times$ $3 \mathrm{~cm})$. The flowers of the wild-type plants were then dipped into the 
Agrobacterium solution and were submerged for 30 seconds. Care was taken not to dip the rest of the plant into the solution because the solution can be detrimental to the health of the plant. The soil of the plant was also held tightly to prevent it from falling into the solution. The pots containing the inoculated plants were then placed on their sides, covered in Saran wrap and left in this position for twelve hours. After twelve hours, the Saran wrap was removed from the plants and they were placed upright in the growth chamber under the conditions described above. The plants were allowed to grow for about three weeks. Then, watering was discontinued and the plants were allowed to dry for about two weeks. Finally, the seeds were harvested.

The seeds were placed in a $15 \mathrm{ml}$ Falcon tube with a few dozen desicating stones to allow further drying of the seeds. The seeds were then sterilized, as described in the following section, after four days under these drying conditions. These are the $T_{0}$ seeds that were later subjected to selection for transformation plants on MS media containing hygromycin.

\subsection{Sterilizing and Imbibing Seeds}

Seeds were sterilized by adding $1 \mathrm{ml}$ of $50 \%$ bleach to $100 \mathrm{ul}$ of $\mathrm{T}_{0}$ seeds that were contained within a $1.5 \mathrm{ml}$ Eppendorf tube. The seeds were allowed to remain in this solution for fifteen minutes. The seed/bleach mixture was then centrifuged at $10000 \mathrm{xg}$ for 20 seconds. The bleach solution was then poured from the tube and replaced with $1 \mathrm{ml}$ of sterile distilled water. The seeds were resuspended in this water and the mixture was centrifuged again 
at $10000 \mathrm{xg}$ for another 20 seconds. This washing procedure was repeated three times. Finally, the seeds were resuspended in $12 \mathrm{ml}$ of $0.1 \%$ agarose and were allowed to sit overnight at $4^{\circ} \mathrm{C}$.

\subsection{Selecting Putative Transformants Using Antibiotic Selection}

Solid MS (Murashige and Skoog) media with hygromycin was prepared by adding $2.165 \mathrm{~g} \mathrm{MS}$ salts to $500 \mathrm{ml}$ of sterile distilled water. Then, the $\mathrm{pH}$ of this solution was adjusted to between 5.7 and 5.8 by using $1 \mathrm{M} \mathrm{KOH}$. Then, $4 \mathrm{~g}$ of agar was added to this solution (Murashige and Skoog, 1962) and the solution was stirred vigorously for two minutes. The solution was autoclaved and allowed to cool to approximately $40^{\circ} \mathrm{C}$. Then, under the fume hood, near the flame, $1.5 \mathrm{ml}$ of hygromycin was added to a final concentration of $30 \mathrm{mg} / \mathrm{L}$. This MS media was poured into Petri plates, with approximately $30 \mathrm{ml}$ of solution added to each plate and left to solidify in these plates for at least two hours.

Then, $3 \mathrm{ml}$ of the agarose/seed mixture was sowed (see section 2.15 Sterilizing and Imbibing Seeds) onto each selection plate using a glass pipette. The plate was rotated and the seeds were dispersed evenly. The plates containing the seeds were allowed to stand partially opened, in the fume hood for 30 minutes to allow the excess liquid to evaporate from the plates. Then, the cover was closed and the Petri plates were sealed with Parafilm and placed in the growth chamber at $22^{\circ} \mathrm{C}$. The seedlings were exposed to 16 hours of light and 8 hours of dark per day. 
In 10 to 14 days, the transformants were visible as healthy, green plants while the non-transformed plants appeared brown and discoloured. The transformants were transferred to soil with one plant per box $(5 \mathrm{~cm} \times 3 \mathrm{~cm})$ in a $26 \mathrm{~cm} \times 56 \mathrm{~cm}$ tray. A transparent cover was placed over the transformed plants for 4 trays in order to retain the moisture. The tray was placed in the growth chamber at $22^{\circ} \mathrm{C}$, under long-day growing conditions. The cover was removed after four days and the plants were allowed to mature.

\subsection{Maintaining the Appropriate Growing Conditions}

The soil in which Arabidopsis thaliana ecotype Columbia seeds as well as putative transformants were added consisted of an autoclaved mix of $80 \%$ sand and $20 \%$ Fisons Levington multi-purpose compost. Seeds and seedlings were placed in a $5 \mathrm{~cm} \times 3 \mathrm{~cm}$ plastic box containing moist soil. The plants were maintained in the growth chamber at $22^{\circ} \mathrm{C}$ under long-day growing conditions (16hours of light and 8 hours of darkness).

\subsection{Preparing E.coli competent cells}

Chemically competent E.coli DH5a cells were made as described in Sambrook et al. (2000). 100ul of frozen competent cells was used to inoculate $1 \mathrm{ml}$ of liquid LB medium and this culture was grown overnight at $37^{\circ} \mathrm{C}$. This $1 \mathrm{ml}$ culture was then added to $100 \mathrm{ml}$ of liquid SOB medium and it was incubated at $37^{\circ} \mathrm{C}(200 \mathrm{rpm})$ for two hours. The culture was then transferred to 
a pre-cooled centrifuge bottle at an $\mathrm{OD}_{600}=0.5$ and it was left on ice for ten minutes. It was then centrifuged at $4000 \mathrm{rpm}$ in a GSA rotor for five minutes at $4^{\circ} \mathrm{C}$. The supernatant was removed with a syringe and the pellet was then resuspended in $33 \mathrm{ml}$ of $\mathrm{RF} 1$ buffer ( $15 \%$ glycerol, $10 \mathrm{mM} \mathrm{CaCl}_{2} .2 \mathrm{H}_{2} \mathrm{O}, 50 \mathrm{mM}$ potassium acetate, $50 \mathrm{mM} \mathrm{MnCl}_{2} .4 \mathrm{H}_{2} \mathrm{O}$ and $100 \mathrm{mM} \mathrm{RbCl}, \mathrm{pH}=5.8$ ) and the mixture was placed on ice for 15 minutes. This suspension was then centrifuged at $4000 \mathrm{rpm}$ for five minutes, the supernatant was removed, the pellet was resuspended in $8 \mathrm{ml}$ of RF2 $\left(15 \%\right.$ glycerol, $75 \mathrm{mM} \mathrm{CaCl}_{2} .2 \mathrm{H}_{2} \mathrm{O}$, $10 \mathrm{mM} \mathrm{RbCl}$ and $10 \mathrm{mM}$ MOPS, $\mathrm{pH}=6.8$ ) and the mixture was incubated on ice for 15 minutes. Finally, 200ul aliquots were dispensed into pre-cooled microtubes and they were stored at $-80^{\circ} \mathrm{C}$.

\subsection{Performing Site-Directed Mutagenesis}

Site-directed mutagenesis using the Quikchange $\circledast$ XL Site-Directed Mutagenesis Kit (Stratagene) was performed according to the protocol as prescribed. Previously, the sequence that codes for the ethylene sensing domain of ETR1 (TMGETR1) and the sequence that codes for the histidine kinase domain of ERS1 (HKERS1) were ligated into the pCambia1301. This construct was used as the template in the site-directed mutagenesis procedure that follows. Complementary primers that match the coding sequence for a region in the TMGETR1 fragment, apart from a single base pair change were designed and synthesized (Invitrogen). The forward and 
reverse primers, showing the single base pair change, were named SDMETR1-fr and SDMETR1-rv (Table 2).

This protocol includes a control reaction to test the efficiency of the site-directed mutagenesis reaction. In the control reaction, the template is comprised of the $\mathrm{pWhitescript}{ }^{\mathrm{TM}}$ plasmid, which contains a stop codon where a glutamine codon would normally appear within the B-galactosidase gene. XL-Gold® ultracompetent cells that are transformed with this plasmid appear white on LB-ampicillin plates that contain IPTG and X-gal, because the Bgalactosidase activity is interrupted. The primers that are included with this kit create a point mutation that reverts the stop codon in the faulty B-

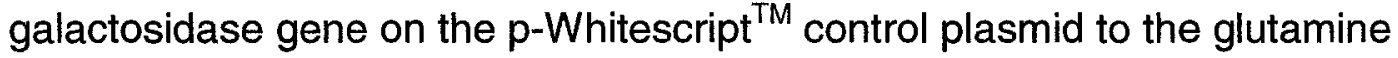
codon that is found in a functional B-galactosidase gene. Competent cells that are subsequently transformed with this plasmid, now containing a functional B-galactosidase gene, will produce blue colonies. This phenotype then confirms that a mutagenized plasmid was selected.

For the sample reaction, the following ingredients were added: $5 \mathrm{ul}$ of 10X reaction buffer; $2 u l(10 \mathrm{ng})$ of double stranded DNA template (this is the pCambia 1301 construct containing the TMGETR1 and HKERS1 fragments, as described above); 1.25ul(125ng) forward primer (described above); 1.25ul(125ng) reverse primer (described above); 1 ul of dNTP; 3ul QuikSolution $\circledast ; 36.5$ ul of sterile distilled water, and; 1 ul PfuTurbo® DNA polymerase. 
This reaction mixture was placed into a thermal cycler that was equipped with a hot-top assembly and the lid temperature was set at $105^{\circ} \mathrm{C}$. The initial denaturation step was at $95^{\circ} \mathrm{C}$ for one minute, followed by a second denaturation step for 50 seconds. Annealing was at $60^{\circ} \mathrm{C}$ for $50 \mathrm{sec}$ and elongation at $68^{\circ} \mathrm{C}, 13$ minutes. This cycle, from the $50 \mathrm{sec}$ denaturation step, was repeated 18 times. After these 18 cycles, a final elongation step at $68^{\circ} \mathrm{C}$ for seven minutes was included.

Following the PCR amplification, 1 ul of $D p n l$ restriction enzyme was added to each tube. These reaction mixtures were mixed several times by pipetting up and down several times and were incubated at $37^{\circ} \mathrm{C}$ for one hour. The purpose of this digestion step was to cut the parental DNA template and to select for mutagenized DNA. Dpnl is specific for methylated and hemimethylated DNA. The original construct for this reaction that was isolated from E.coli strain DH5a was Dam methylated (as are plasmids from most E.coli) and is, therefore, susceptible to Dpnl digestion.

Following this digestion step, the nicked vector DNA which had incorporated the desired mutation was then transformed into XL10-Gold® Ultracompetent cells according to the manufacturer's recommendations. 


\section{Results}

\subsection{Assembly of Chimeric Ethylene Receptors}

One of the goals of this project was to construct a chimeric gene derived from the transmembrane and GAF domains of the ETR1 gene and the histidine-kinase domain of the ERS1 gene. A second objective was to perform site-directed mutagenesis on this construct to imitate the cysteine to tyrosine mutation at amino acid 65 in the etr1-1 mutant allele. Wild-type Arabidopsis plants were then transformed with both the chimeric construct and the mutant chimeric allele. Several attempts were also made to clone a chimeric gene composed of the TMGERS1 and HKETR1 fragments into the pCambia 1301 plant transformation vector. However, these cloning attempts were unsuccessful because it was determined that the fragments were forming concatamers before being inserted into the pCambia 1301 vector. An alternative method to clone this chimeric gene into the pCambia 1301 vector would be as follows: 1) Initiate a ligation reaction with the fragments TMGERS1 and HKETR1; 2) After about one hour, remove some of the ligate and use it as a template in a PCR reaction that would utilize the TMGERS1-fr and HKETR1-rv primers to amplify the TMGERS1/HKETR1 chimeric gene; 3 ) Run the PCR product on an agarose gel; 4) Purify that fragment that corresponds to the TMGERS1/HKETR1 chimeric fragment and clone it into the PGEM-T囚easy vector; 5) Digest the chimera from pGEM-T囚easy and ligate it into pCambia 1301. 
The DNA fragment that codes for the transmembrane domain and the GAF domain of ETR1 (TMGETR1) was amplified by PCR using the cDNA of wild-type Arabidopsis thaliana ecotype Columbia as the template. Primers were designed such that the $\mathrm{Ncol}$ restriction site would be incorporated into the 5 end of this fragment and the Apal restriction site at the 3 end. The histidine kinase encoding domain of ERS1 (HKERS1) was amplified by PCR using the CDNA of the ERS mutant as the template. The primers incorporated an Apal restriction site at the 5 ' end and a BstEll restriction site at the 3 end. These fragments were ligated together.

Digestion of the pCambia 1301 plasmid with $\mathrm{Ncol}$ and BstEll removes the GUS reporter for replacement by the recombinant ethylene receptor. Ligation of the chimeric DNA fragment into the plant transformation vector, pCambia 1301, using these restriction sites places it in the correct orientation for transcription to be driven by the CaMV 35 S promoter.

The restriction sites, Ncol, Apal and BstEll within the chimeric DNA were chosen because they were the only restriction sites, out of the available cloning sites within the pCambia 1301 vector, that were not present within either ETR1 or ERS1. One potential complication noted with the restriction site, $\mathrm{Ncol}$, is that it places a start codon into the $5^{\prime}$ untranslated region of the TMGETR1 DNA. However, any translation initiation at this start codon within the $\mathrm{Ncol}$ site is abruptly terminated by a stop codon, upstream of the true start codon (See Figure 17B). Therefore, translation of the chimeric receptor should proceed normally. 
Figure 11. Experimental Design for Sub-cloning the TMGETR1/HKERS1 Chimeric DNA Fragment into pCambia 1301

From the 12kb pCambia 1301 plasmid, a 2049 bp Gus reporter gene was replaced by a chimeric DNA insert, $2320 \mathrm{bp}$ long, composed of TMGETR1 and HKERS1 fragments (Figure is adapted from a diagram at www.cambia.org). 


\section{Insert}

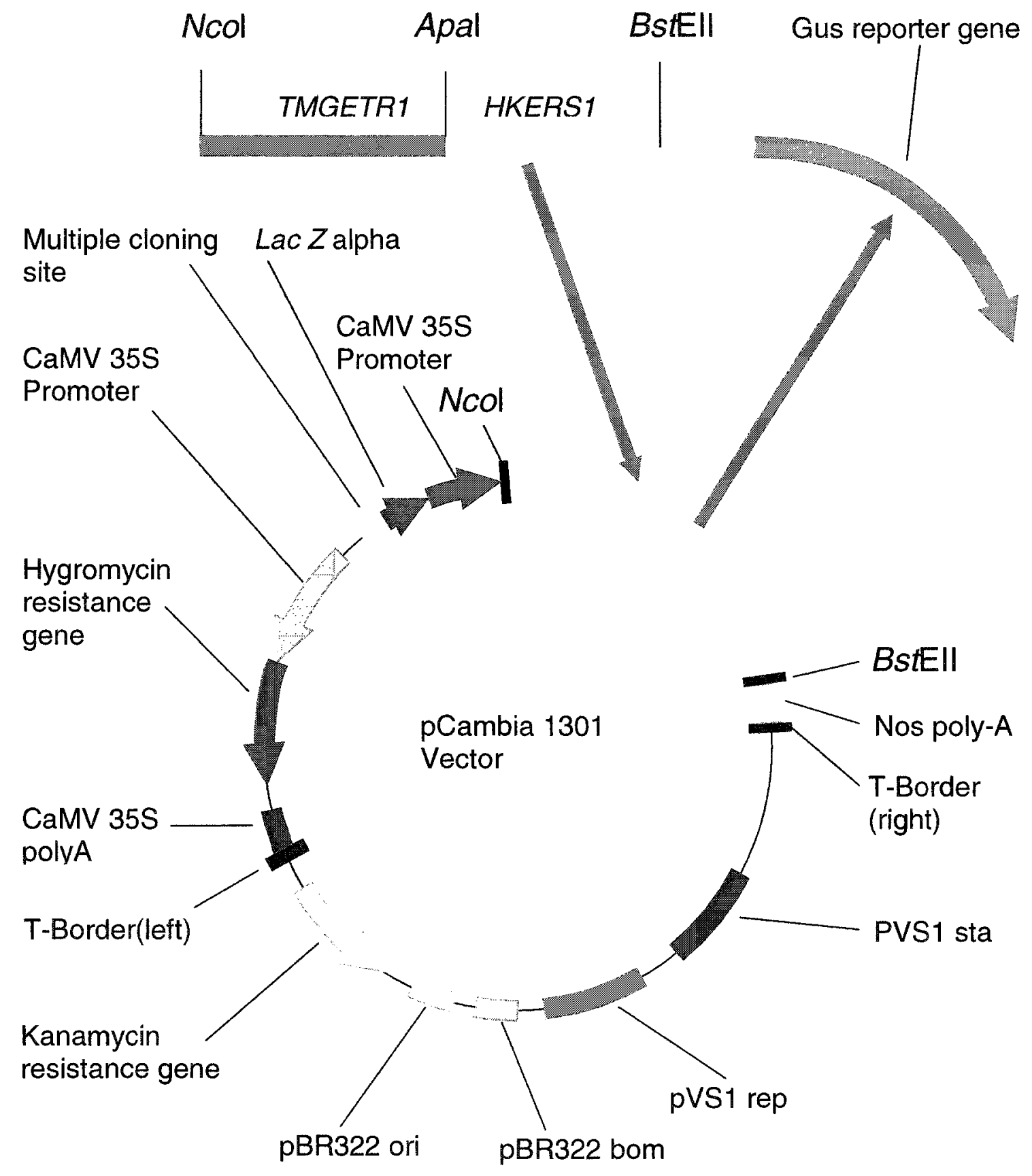




\subsection{Amplification of the Desired ETR1 and ERS1 Fragments}

Total RNA was isolated from wild type Arabidopsis thaliana ecotype Columbia plants that were two weeks old. The Arabidopdis life cycle is very rapid, growing from a germinating seed to a flowering plant in 4 to 5 weeks (Boyes et al., 2001). At two weeks, the young plant is in a full vegetative growth stage, having about 10-12 leaves that are oval in shape, approximately $2 \mathrm{~cm}$ long and $1 \mathrm{~cm}$ wide. The first flower buds have not yet formed. Plants at this age yield high concentrations of total RNA. Ribosomal bands are clearly visible in the total RNA sample (Fig. 12A). Through analysis with the spectrophotometer it was determined that the concentration of RNA was approximately $0.4 \mathrm{ug} / \mathrm{ul}$.

The total RNA that was isolated in the above step was used to make first strand $\mathrm{cDNA}$. The choice of using CDNA over genomic DNA as the template in the PCR reactions was made because the size of the chimeric insert would be smaller, 2074bp instead of $2764 \mathrm{bp}$, and this would make it easier to transform E.coli and Agrobacterium. The same extraction procedure was used to isolate RNA from ERS mutant plants. In addition, the CDNA synthesis procedure, primed with oligo dT (18) (Life Technology) was used for both of the RNA samples. Surprisingly, when the cDNA that originated from the mutant plant's RNA was used in the RT-PCR reaction, only bands corresponding to unspliced, genomic DNA were detected. The final chimeric DNA construct consisted of the CDNA of the ETR1 transmembrane domain-encoding region and of the genomic DNA of the ERS1 histidine kinase-encoding region. 
Figure 12. PCR Amplification of the ETR1 and ERS1 Fragments (A) RNA from Arabidopsis thaliana Lane 1. 5ul 1Kb DNA ladder. Lane 2. 1ul of total plant RNA.

(B) Fragments Obtained by RT-PCR using RNA Originating from Wild-type Plants. Lane 1. 5ul of $1 \mathrm{~Kb}$ DNA ladder. Lane 2. The TMGETR1 cDNA fragment corresponds to the expected length of $1103 \mathrm{bp}$. Lane 3 . The HKERS1 cDNA fragment corresponds to the expected length of $971 \mathrm{bp}$. Lane 4. The HKETR1 cDNA fragment corresponds to the expected length of $1219 \mathrm{bp}$.

(C) Fragments Obtained by RT-PCR using RNA Originating from an ERS Gain-of-Function Mutant Plant. Lane 1. 5ul of 1Kb DNA ladder. Lane 2. HKERS1 genomic DNA fragment. It corresponds to the expected length of $1217 \mathrm{bp}$. 


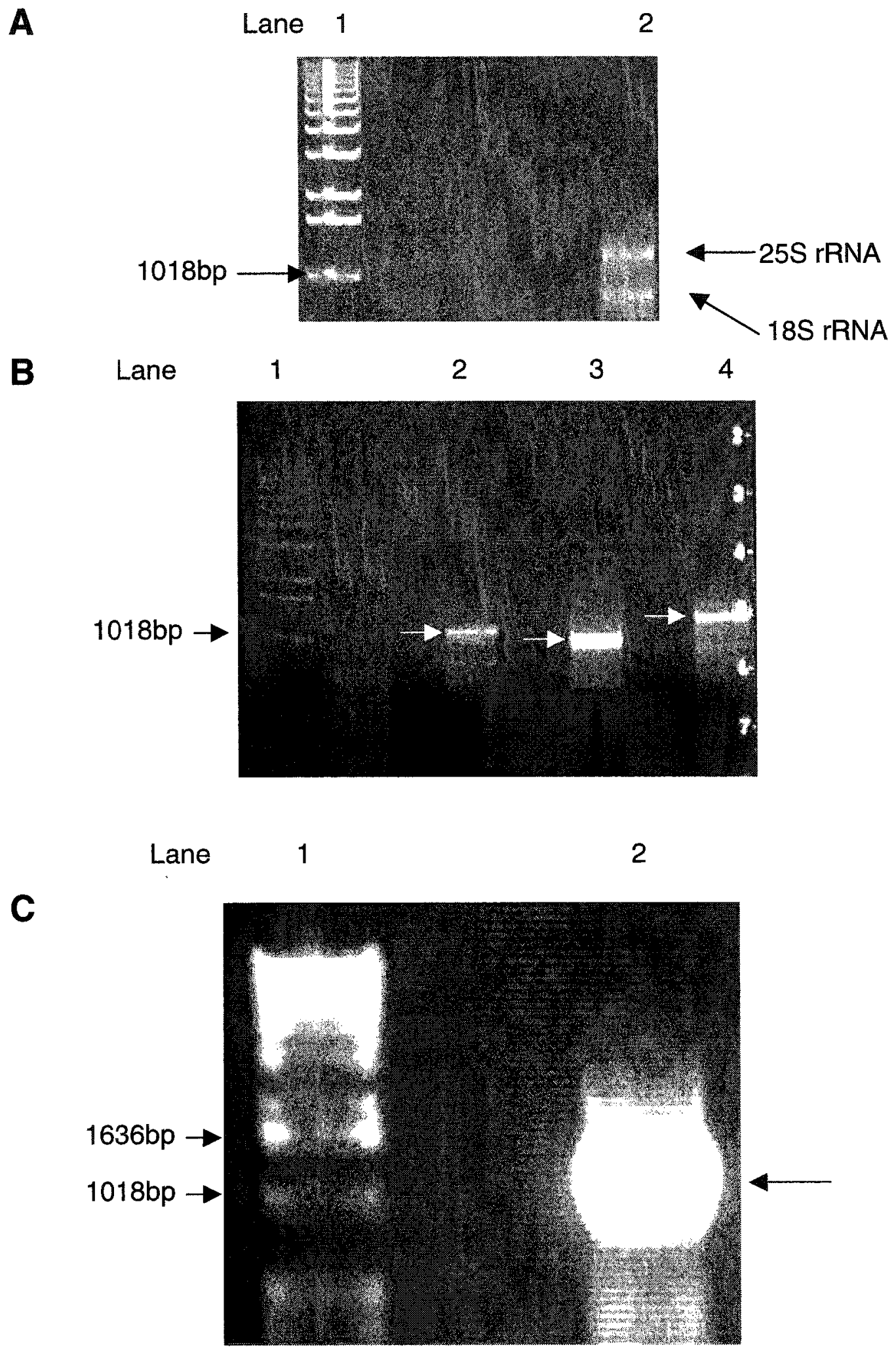


Table 3. Lengths of Expected CDNA and Genomic DNA of the ETR1 and ERS1 Fragments

\begin{tabular}{|c|c|c|}
\hline Fragment to be Cloned & Length of cDNA & Length of Genomic DNA \\
\hline TMGETR1 & $1103 \mathrm{bp}$ & $1547 \mathrm{bp}$ \\
\hline TMGERS1 & $1060 \mathrm{bp}$ & $1390 \mathrm{bp}$ \\
\hline HKERS1 & $971 \mathrm{bp}$ & $1217 \mathrm{bp}$ \\
\hline HKETR1 & $1219 \mathrm{bp}$ & $1619 \mathrm{bp}$ \\
\hline
\end{tabular}




\subsection{Cloning of PCR Products into the pGEM-Teasy® Vector}

To facilitate the cloning process, the TMGETR1, TMGERS1, HKERS1 and HKETR1 fragments were first separately ligated into the pGEM-Teasy® vector. The pGEM-Teasy® vector (Promega) was supplied predigested with EcoR $\vee$ and containing $3^{\prime}$ terminal thymidines. These terminal thymidines prevent the recircularization of the vector and promote ligation of amplified PCR fragments because the Taq DNA polymerase that was used for amplification adds a single complementary deoxyadenosine to the $3^{\prime}$ ends of the amplified fragments (Promega).

In designing the primers that were used to amplify the ETR1 and ERS1 fragments, specific restriction sites were incorporated into the 5' and 3' ends in order to facilitate later cloning steps. At the $5^{3}$ ends of the TMGETR1 and TMGERS1 fragments, an Ncol restriction site was added. In addition, an Apal restriction site was incorporated onto their 3' ends. At the 5' ends of HKERS1 and HKETR1, an Apal restriction site was added. A BstEll restriction site was added to their 3' ends.

Several of the clones selected from this ligation are shown in Fig. 13A. To confirm that the unique restriction sites, which had been designed into the PCR primers, were present, the clones $p$ TMGETR1 and $p H K E R S 1$ were tested by digestion. When pTMGETR1 was double digested with Ncol and Apal, the predicted insert of $1.1 \mathrm{~Kb}$ was released (Fig. 13B). Similarly, digestion of pHKERS1 with Apal and BstEll generated the insert size of 1.2 $\mathrm{Kb}$ (Fig. 13C). This HKERS1 fragment was longer that expected and it was 
later confirmed by sequencing that it consisted of genomic DNA rather than cDNA. 
Figure 13. Evidence of the ETR1 and ERS1 Inserts in the pGEM-Teasy® Recombinant Clones

(A) Representative clones containing the ETR1 and ERS1 PCR amplification products in the pGEM-Teasy® vector. Lane 1. TMGETR1 cDNA first eluate. Lane 2. TMGETR1 cDNA second eluate. Lane 3. TMGETR1 genomic DNA, first eluate. Lane 5 and 6. Empty vector. Lane 7. TMGERS1 genomic DNA, first eluate. Lane 9. HKETR1 genomic DNA. Lane 10.5ul of 1Kb DNA ladder. (B) TMGETR1 digested from pTMGETR1. Lane 1.5ul of $1 \mathrm{~Kb}$ DNA ladder. Lane 2. Undigested pTMGETR1 containing TMGETR1 insert. Lane 3. Digest of $p$ TMGETR1 with Ncol and Apal.

(C) HKERS1 digested from pHKERS1. Lane $1.5 \mathrm{ul}$ of $1 \mathrm{~Kb}$ DNA ladder. Lane 2. Digest of pHKERS1 with Apal and BstEll. 


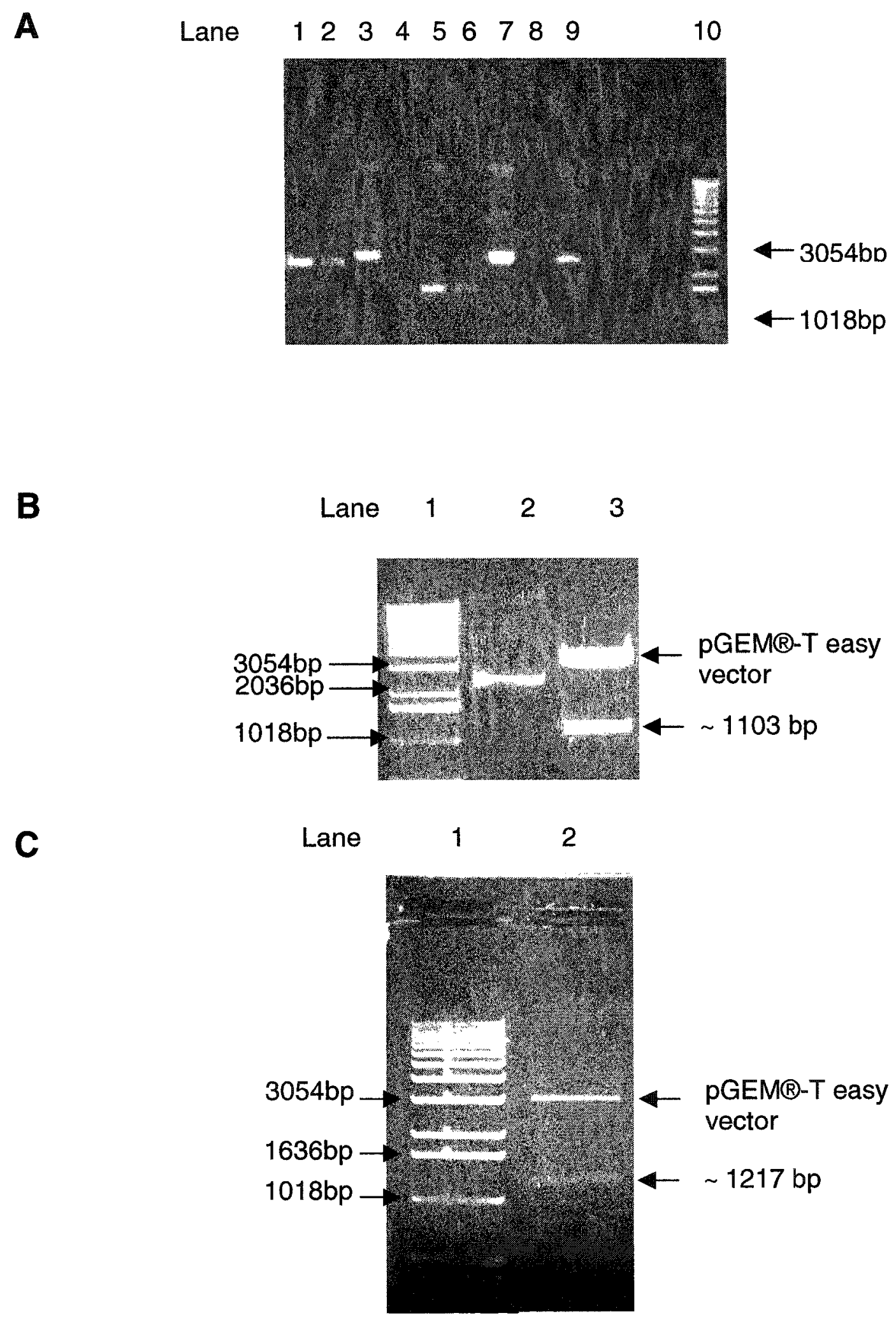




\subsection{Assembly of Chimeric Ethylene Receptors into pCambia 1301}

The pCambia 1301 vector was selected for expression of chimeric receptors in Arabidopsis because it has a CaMV 35 S promoter to drive the expression of the insert and it encodes the hygromycin resistance gene for plant selection. This a popular selection antibiotic because it is easy to distinguish between transformed and non-transformed plants (Nakazawa and Matsui, 2003).

The Ncol, Apal fragment of pTMGETR1 (Fig. 13B) was first ligated to the Apal, BstEll fragment of pHKERS1 (Fig. 13C) and this chimeric fragment was ligated into the open pCambia 1301 plant transformation vector.

A double restriction digest using the restriction enzymes, $\mathrm{Ncol}$ and BstEll, was performed on the pCambia 1301 plant transformation vector because both restriction enzymes operate at $100 \%$ efficiency within the same buffer. This digestion served two purposes: 1) It opened the vector in order to receive the insert, and; 2) It provided restriction site overhangs in order to facilitate the insertion of the chimeric DNA. In the double digest, a Gus reporter gene, 2049 base pairs long, was released. The longer fragment, 9788 base pairs in length, was cut from the gel and was subsequently purified and ligated to the chimeric receptor construct.

\subsection{Confirming the Presence of TMGETR1 and HKERS1 in pCambia 1301}

To verify that the ethylene receptor construct was successfully ligated into the pCambia 1301 vector, several putative recombinant plasmids were 
isolated and electrophoresed on a one percent agarose gel (Fig. 14A). The construct is $12 \mathrm{~Kb}$ in length and the apparent super-coiled, open circle and linear forms of the plasmid appear to be at the correct locations on the gel. Plasmids from the four clones migrated the same distance on the gel.

Four PCR reactions were performed to ensure that the TMGETR1 /HKERS1 chimeric DNA was inserted correctly into pCambia 1301. The TMGETR1 forward primer that was used to initially obtain the TMGETR1 fragment was used in combination with the HKERS1 reverse primer that was initially used to obtain the HKERS1 fragment. The templates for these PCR reactions were four pCambia 1301 constructs, putatively containing the TMGETR1/ HKERS1 chimeric DNA. When these reactions were performed, DNA fragments were amplified whose lengths corresponded to the predicted length of the TMGETR1/HKERS1 chimeric DNA, 2320bp. Colony 2, 3 and 4 in figure 14B show the amplified chimeric fragments and all of the bands are consistent in that they have migrated the same distance in the gel. Through sequencing, it was determined that TMGETR1 was a cDNA fragment and that HKERS1 was a genomic DNA fragment. See table 2. It appears that the TMGETR1/HKERS1 inserts are not in colony 1. See lane 2, Figure 14B. A double digestion reaction was carried out using the restriction enzymes Ncol and BstEll on one of the pCambia 1301 constructs that putatively contained the TMGETR1/HKERS1 chimeric DNA. This digestion was performed in order to confirm that the TMGETR1/HKERS1 chimeric DNA was present in the vector. In this digestion, a fragment was released that 
corresponded to the predicted length of the inserted DNA fragment, $2320 \mathrm{bp}$ (Fig. 14C). 
Figure 14. Evidence of TMGETR1 and HKERS1 inserts in pCambia 1301 (A) pCambia 1301 Containing the Inserts. Lane 1. $5 \mathrm{ul}$ of $1 \mathrm{~Kb}$ DNA ladder. Lane 2. pCambia 1301 containing TMGETR1 + HKERS1 inserts, colony 1. Lane 3. pCambia 1301 containing TMGETR1 + HKERS1 inserts, colony 2. Lane 4. pCambia 1301 containing TMGETR1 + HKERS1 inserts, colony 3. Lane 5. pCambia 1301 containing TMGETR1 + HKERS1 inserts, colony 4. (B) Amplified Fragments of TMGETR1 and HKERS1. Lane 1. 5ul of $1 \mathrm{~Kb}$ DNA ladder. Lane 2. This PCR reaction did not yield the desired product. The small band that is present diffused from the adjacent lane. Lane 3. Amplified PCR product of TMGETR1/HKERS1, colony 2. Lane 4. Amplified PCR product of TMGETR1/HKERS1, colony 3. Lane 5. Amplified PCR product of TMGETR1/HKERS1, colony 4.

(C) Fragments released from recombinant pCambia 1301clones. Lane 1.5ul of $1 \mathrm{~Kb}$ DNA ladder. Lane 2. TMGETR1/HKERS1 chimeric DNA released after double digestion from pCambia 1301 construct, colony 2. Lane 3. TMGETR1/HKERS1 chimeric DNA released after double digestion from pCambia 1301 construct, colony 3. Lane 4. TMGETR1/HKERS1 chimeric DNA released after double digestion from pCambia 1301 construct, colony 4 . Lane 5. Undigested pCambia 1301 construct containing TMGETR1/HKERS1 inserts. 

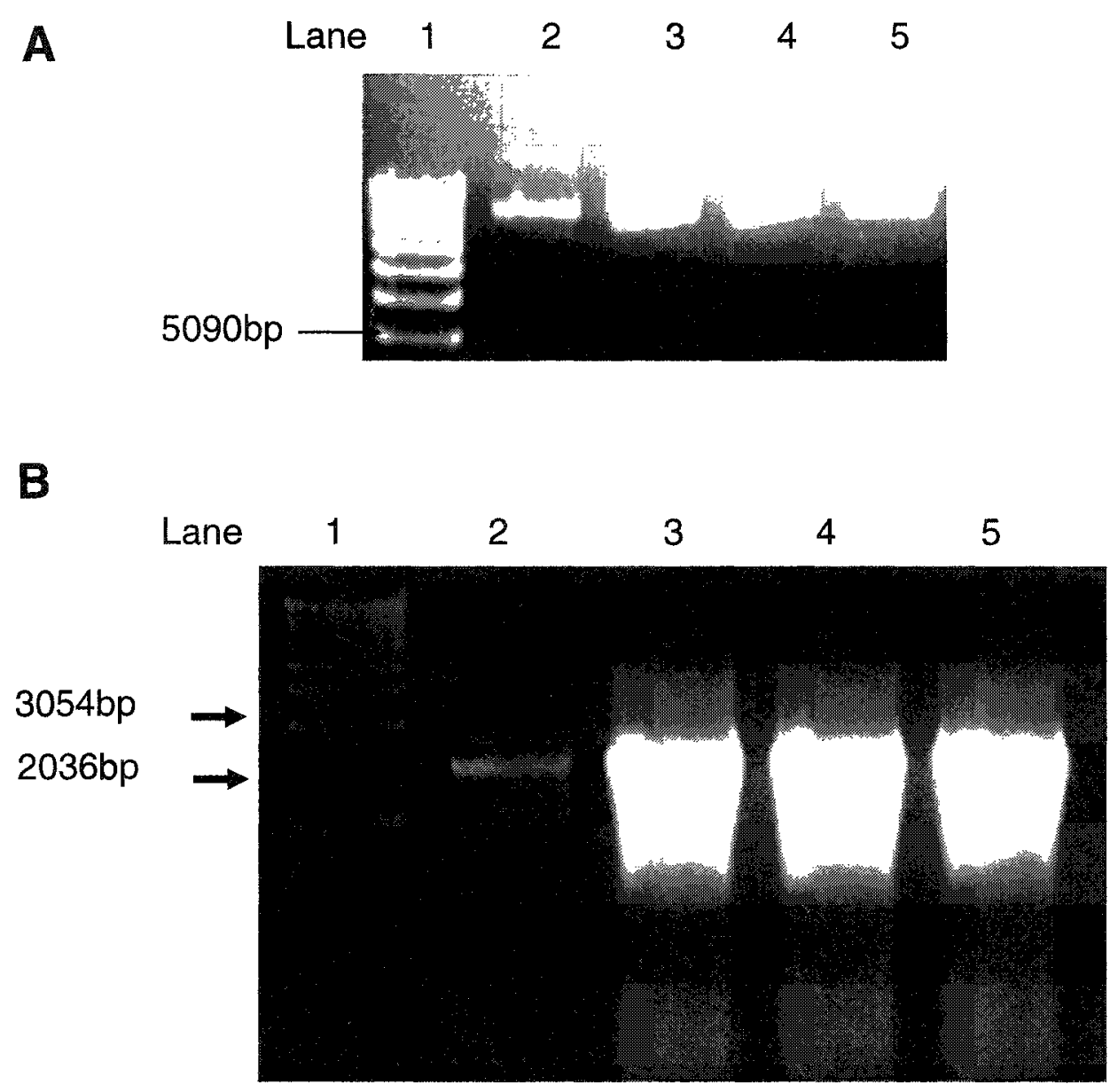

C

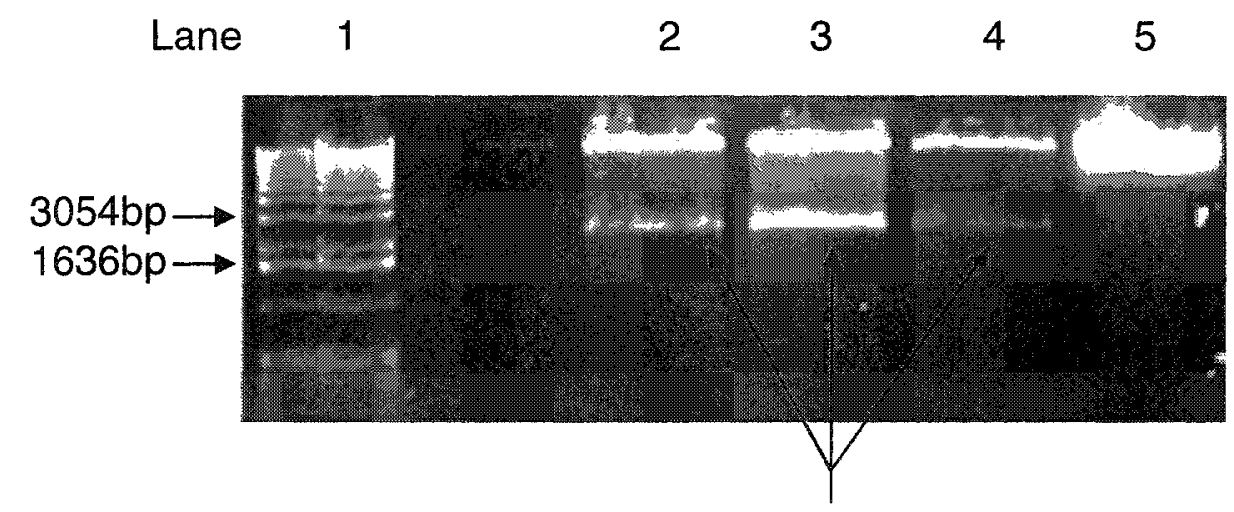

\author{
TMGETR1 + \\ HKETR1 \\ chimeric DNA
}




\subsection{Sequence Analysis of pCambia Recombinant Plasmids}

To confirm that the TMGETR1 and the HKERS1 fragments were present in the recombinant pCambia 1301 vectors, one of the clones was selected for DNA sequencing. The forward primer that was used in this sequencing reaction was TMGETR1-fr (Table 2).

The resulting $846 \mathrm{Nt}$ sequence was nearly identical to the expected TMGETR1 CDNA sequence (Fig. 15A). An inspection of the trace electropherogram suggests that the apparent frameshifts correspond to doublets. This clone was also sequenced from a primer designed from the pCambia 1301 vector near the 3' end of the HKERS1 fragment, named ConfirmERS1-rv (Table 2).

From the gaps in the sequence alignment between the ConfirmERS1n extension product and the HKERS1 cDNA it was apparent that the HKERS1 fragment that was cloned into pCambia 1301 was genomic DNA, not the cDNA sequence (Fig. $15 \mathrm{~B}$ and $\mathrm{C}$ ). In the first intron that is evident in the HKERS1 genomic sequence, from nucleotides 82 to 159 , the canonical $G$ and $T$ in the splice donor site at positions 82 and 83 are present. However, at positions 158 and 159, the nucleotides $T$ and $G$ are present instead of the canonical $A$ and $G$ that are normally found in these positions in the splice acceptor site (Hebsgaard et al., 1996).

In the second intron, from nucleotides 295 to 383 , in the genomic HKERS1 sequence, the canonical splice acceptor site nucleotides $\mathrm{G}$ and $\mathrm{T}$ 
are found at positions 295 and 296 and the canonical splice donor site nucleotides are found at positions 382 and 383 (Hebsgaard et al., 1996).

Although first strand cDNA was used as the template DNA in several RT-PCR reactions in order to obtain the following fragments: TMGETR1; TMGERS1; HKETR1, and; HKERS1. In some instances, the fragment that was obtained corresponded to the length of the genomic DNA fragment. Therefore, there may have been genomic DNA contamination in the cDNA sample that was used as the template in the RT-PCR reaction. 
Figure 15. Sequencing Results of the pCambia 1301 Construct (A) Comparison of the known TMGETR1 CDNA fragment with the recombinant pCambia 1301 construct. The upper line in this sequencing comparison is TMGETR1 CDNA fragment from nucleotide 3 to nucleotide 849 . The lower line shows the results obtained from the sequencing reaction. (B) The sequenced fragment was compared with the known HKERS1 cDNA sequence. The upper line in this sequencing comparison is the HKERS1 cDNA fragment from nucleotide 481 to nucleotide 861 . The lower line shows the results obtained by the sequencing reaction.

(C) The sequenced fragment was compared with the known HKERS1 genomic DNA sequence. The upper line represents the HKERS1 genomic DNA sequence from 560 base pairs to 1205 base pairs (NCBI). The lower line represents the sequencing results. 


\begin{abstract}
A
3 GGAAGTCTGCAATTGTATTGAACCGCAATGGCCAGCGGATGAATTGTTAATGAAATACCA \|\|\|\|\|\|\|\|\|\|\|\|\|\|\|\|\|\|\|\|\|\|\|\|\|\|\|\|\|\|\|\|\|\|\|\| AGAAGTCTGCAATTGTATTGAACCGCAATGGCCAGCGGATGACTTGTTAATGAAATACCA

63 ATACATCTCCGATTTCTTCATTGCGATTGCGTATTTTTCGATTCCTCTTGAGTTGATTTA

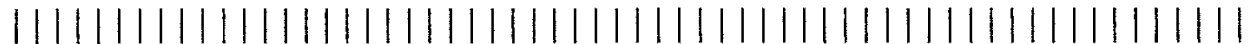

158 ATACATCTCCGATTTCTTCATTGCGATTGCGTATTTTTCGATTCCTCTTGAGTTGATTTA

123 CTTPGTAAGAAATCAGCCGTGTTTCCGTATAGATGGGTACTTGTTCAGTTTGGTGCTTT

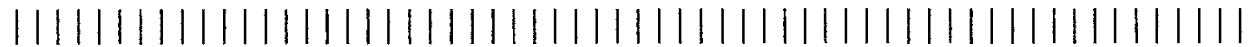

218 CTTTGTGAAGAAATCAGCCGTGTTTCCGTATAGATGGGTACTTGTTCAGTTTGGTGCTTT

183 TATCGTTCTPTGTGGAGCAACTCATCTTATTAACT'TATGGACTT'TCACTACGCATTCGAG

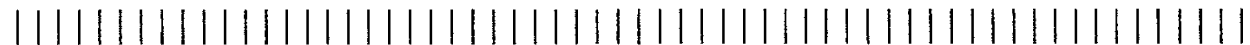

278 TATCGTTCTTTGTGGAGCAACTCATCTTATTAACTTATGGACTTTCACTACGCATTCGAG

243 AACCGTGGCGCTTGTGATGACTACCGCGAAGGTGTTAACCGCTGTTGTCTCGTGTGCTAC

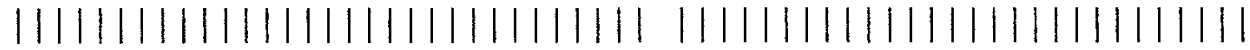
338 AACCGTGGCGCTTGTGATGACTACCGCGAAG . TGTTAACCGCTGTTGTCTCGTGTGCTAC

303 TGCGTTGATGCTTGTTCATATTATTCCTGATCTTTTGAGTGTTAAGACTCGGGAGCTTTT

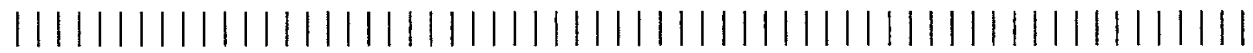
397 TGCGTTGATGCTTGTTCATATTATTCCTGATCTTTTGAGTGTTAAGACTCGGGAGCTTTT

363 CTTGAAAAATAAAGCTGCTGAGCTCGATAGAGAAATGGGATTGATTCGAACTCAGGAAGA |||||||||||||||||||||||||||||||||||||||||||||||||| 457 CTTGAAAAATAAAGCTGCTGAGCTCGATAGAGAAATGGGATTGATTCGAACTCAGGAAGA

423 AACCGGAAGGCATGTGAGAATGTTGACTCATGAGATTAGAAGCACTTTAGATAGACATAC | 1||||||||||||||||||||||||||||||||||||||||||||||||||||||

483 TATTTTAAAGACTACACTTGTTGAGCTTGGTAGGACATTAGCTTTGGAGGAGTGTGCATT

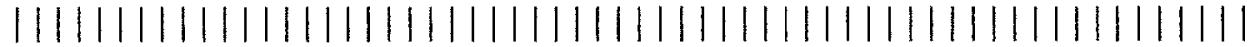
576 TATTTTAAAGACTACACTTGTTGAGCTTGGTAGGACATTAGCTTTGGAGGAGTGTGCATT

543 GTGGATGCCTACTAGAACTGGGTTAGAGCTACAGCTTTCTTATACACTTCGTCATCAACA ||||||||||||||||||||||||||||||||||||||||||||||||||||

636 GTGGATGCCTACTAGAACTGGGTTAGAGCTACAGCTTTCTTATACACTTCGTCATCAACA

603 TCCCGTGGAGTATACGGTTCCTATTCAATTACCGGTGATTAACCAAGTGTTTGGTACTAG ||||||||||||||||||||||||||||||||||||||||||||||||||| 696 TCCCGTGGAGTATACGGTTCCTATTCAATTACCGGTGATTAACCAAGTGTTTGGTACTAG

663 TAGGGCTGTAAAAAT . ATCTCCTAATTCTCCTGTGGCTAGGTTGAGACCTGTTTCTGGGA

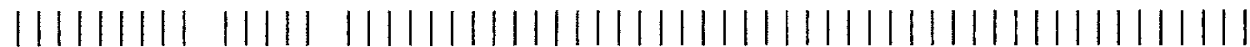
756 TAGGGCTGTCAAAATCATCTCCTAATTCTCCTGTGGCTAGGTTGAGACCTGTTTCTGGGA

722 AATATATGCTAGGGGAGGTGGTCGCTGTGAGGGTTCCGCTTCTCCACCTTTCTAATTTTC

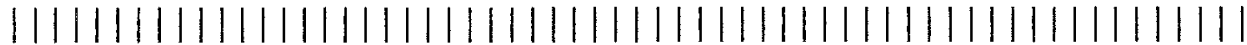

816 AATATATGCTAGGGGAGGTGGTCGCTGTGAGGGTTCCGCTTCTCCACCTTTCTAATTTTC

782 AGATTAATGACTGGCCTGAGCTTTCAACAAAGAGATATGCTTTGATGGTTTTGATGCTTC \|\|\|\|\|\|\|\|\|\|\|\|\|\|\|\|\|\|\|\|\|\|\|\|\|\|\|\|\|\|\|\|\|\|\|\|
\end{abstract}


842 CTTCAGAT

1|| 1\|\|||

936 CTTCAGAT

\section{B}

481 ATCATGAAACCCGAGTCCTTACAAGAATTACCATCTCCAGAATTTTTTCCAGTTCTCAGT 1 ATCATGAAMCCCGAGTCCTTACAAGAATTACCATCTCCAGAATTTTTTCCAGTTCTCAGT

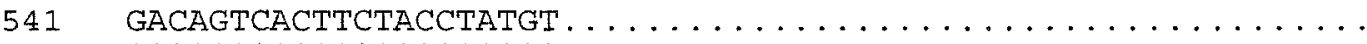
1\|\|\|\|\|\|\|\|\|\|\|\|$\|$

61 GACAGTCACTTCTACCTATGT GCAGGTTAGCCCCAATCTACAAATTACTAAACTACAA

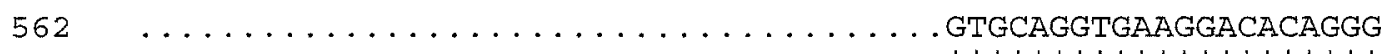

121 AgTTAAGCTTCTTACTGTGTTCTTACTGTTATAATCA $|\||\||\||\||\||\||\||\|\mid\|$

583 TGTGGAATTCACACACAAGACATTCCTTTGCTCTTTACCAAATTTGTACAGCCTCGGACC ||||||||||||||||||||||||||||||||||||||||||||||||| 181 TGTGGAATTCACACACAAGACATTCCTTTGCTCTTTACCAAATTTGTACAGCCTCGGACC

643 GgAACTCAGAGGAACCATTCCGGTGGAGGACTCGGGCTAGCTCTCTGTAAACG . . . .

241 GGAACTCAGAGGAACCATTCCGGTGGAGGACTCGGGCTAGCTCTCTGTAAACGEAACAC

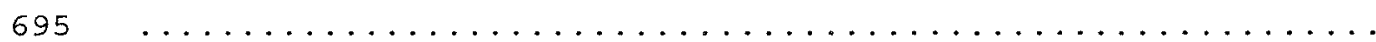

301 CCCAAAAGTATGTATAAGTTATAAGCAGATGGTGTTACAAATAGCTAAAAGGCAAGTTTC

$695 \ldots \ldots \ldots \ldots \ldots \ldots \ldots$. . . . . . . .

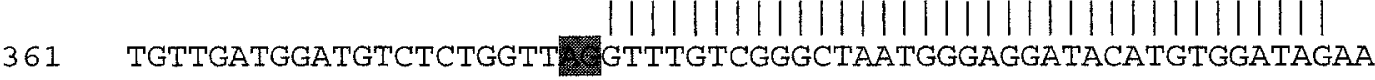

733 AGTGAAGGCCTAGAGAAAGGCTGCACAGCTTCGTTCATCATCAGGCTTGGTATCTGCAAC \|\|\|\|\|\|\|\|\|\|\|\|\|\|\|\|\|\|\|\|\|\|\|\|\|\|\|\|\|\|\|\|\|\|\|\|\|\| 421 AGTGAAGGCCTAGAGAAAGGCTGCACAGCTTCGTTCATCATCAGGCTTGGTATCTGCAAC

793 GGTCCAAGCAGTAGCAGTGGTTCAATGGCGCTACATCTTGCAGCTAAATCACAAACCAGA $|\|\|\|\mid\|\|\|\|\|\|\|\|\|\|\|\|\|\|\|\|\|\|\|\|\|\|\|\|\|\|\|\|\|\|\|\|\|$

481 GGTCCAAKCAGTAGCAGTGGTTCAATGGCGCTACATCTTGCAGCTAAATCACAAACCAGR

853 CCGTGGAAC

11\|\|\|\|

541

CCGTGGAAC 


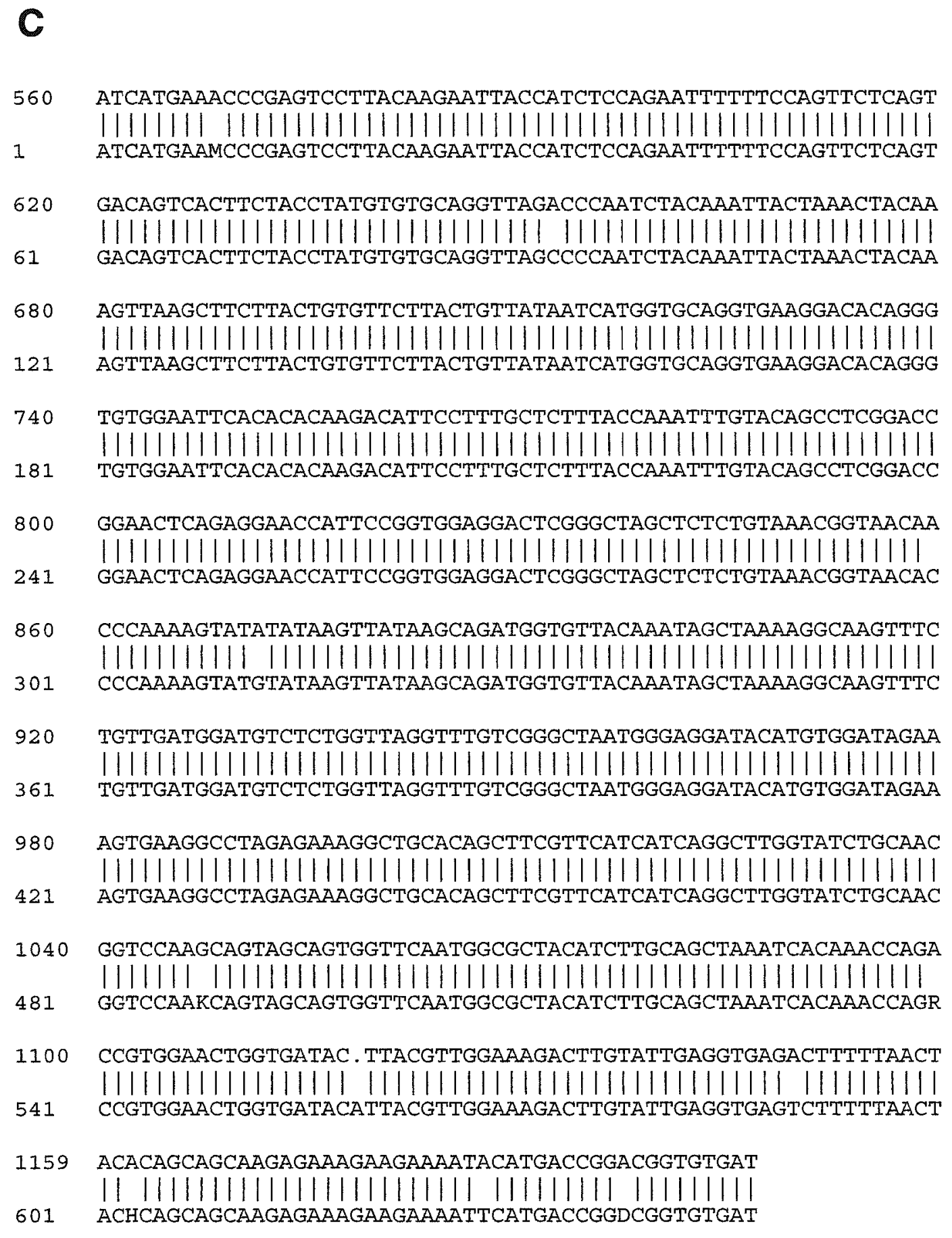




\subsection{Site-Directed Mutagenesis of the pCambia 1301 Construct}

A single nucleotide change within the ETR1 coding sequence (Hall et al., 1999) results in the etr1-1 mutant allele. When this allele is expressed in Arabidopsis it results in a dominant, gain of function mutation that locks the ethylene receptor into an active signaling state (Zhoa, 2002). The etr1-1 mutant seeds also experience difficulty in germinating (Ecker, 1995). It was hypothesized that when a chimeric gene, having the transmembrane domain and GAF domains from the etr1-1 mutant and the histidine kinsase domain of ERS1, is expressed in Arabidopsis, the dormancy phenotype of the seeds would be normal. This would result because the histidine kinase domain of ERS1 is not followed by a response regulator domain (Gamble, 2002). Therefore the signal that results from the mutation upstream within the transmembrane domain would not be transduced to downstream regulators.

The plasmid $p C a m-E T R 1 / E R S 1$ consists of a chimeric gene composed of the ethylene binding and GAF domains of ETR1 and the histidine kinase domain of ERS1 in pCambia 1301. To test the hypothesis that the dormancy phenotype of seeds would be normal as described above, this construct was used as a template in a PCR reaction to perform sitedirected mutagenesis (Stratagene). The goal of this experiment was to create a single base pair change from a guanine to an adenine at position 194 in the ETR1 coding sequence to mimic the mutation in the etr1-1 mutant allele.

To confirm that $p C a m-E T R 1 / E R S 1$ was otherwise preserved following site-directed mutagenesis, a double digestion was carried out using the 
restriction enzymes $\mathrm{Ncol}$ and BstEll and gel electrophoresis. As shown in Fig. $16 \mathrm{~B}$, two bands were visible on this gel, consisting of the empty pCambia 1301 vector (upper band) and a fragment of the length predicted for the chimeric gene (lower band). The QuikChange $₫$ XL Site-Directed Mutagenesis Kit that was used includes a high fidelity PfuTurbo® DNA polymerase that can amplify targets up to $19 \mathrm{~Kb}$ in length (Stratagene). The plasmid that was amplified in this experiment was $12 \mathrm{~Kb}$ and was close to this limit for this DNA polymerase, therefore this digestion was performed to ensure that the plasmid was preserved.

As further confirmation that the chimeric gene was still present following site-directed mutagenesis, PCR reactions were performed with the primers TMGETR1-fr and HKERS1-rv (Table 2), using the newly generated pCamETR1/ERS1 as template DNA. A 2300 bp band was amplified from several of the selected clones (Fig. 16C), confirming that the chimeric gene was present within the constructs. DNA sequencing was later performed to confirm it. 
Figure 16. The Plasmid Generated by Site-Directed Mutagenesis (A) A gel image of two pCambia 1301 constructs after having undergone sitedirected mutagenesis. Lane 1.5ul of $1 \mathrm{~Kb}$ DNA ladder. Lane 2. pCambia construct generated by site-directed mutagenesis, colony 1. Lane 3. pCambia construct generated by site-directed mutagenesis, colony 2. Lane 4. Positive control, pCambia 1301 construct containing TMGETR1/HKERS1 inserts. (B) A double digest reaction with $\mathrm{Ncol}$ and $\mathrm{BstEll}$ on the newly generated pCambia 1301 construct to release the TMGETR1/ HKERS1 chimeric DNA, putatively containing a single point mutation. Lane $1.5 \mathrm{ul}$ of $1 \mathrm{~Kb}$ DNA ladder. Lane 2. The pCambia 1301 construct, generated by site-directed mutagenesis, was digested to release the TMGETR1/HKERS1 fragment, putatively, with a newly generated point mutation.

(C) PCR-Amplified Chimeric DNA Containing a Single Point Mutation. Lane 1. Amplified PCR product of TMGETR1/HKERS1 containing a single point mutation, colony 1. Lane 2. Amplified PCR product of TMGETR1/HKERS1, putatively containing a single point mutation, colony 2. Lane 3. Amplified PCR product of TMGETR1/HKERS1, putatively containing a single point mutation, colony 3. Lane 4. Amplified PCR product of TMGETR1/HKERS1, putatively containing a single point mutation, colony 4 . Lane $5.5 \mathrm{ul}$ of $1 \mathrm{~Kb}$ ladder. 
A
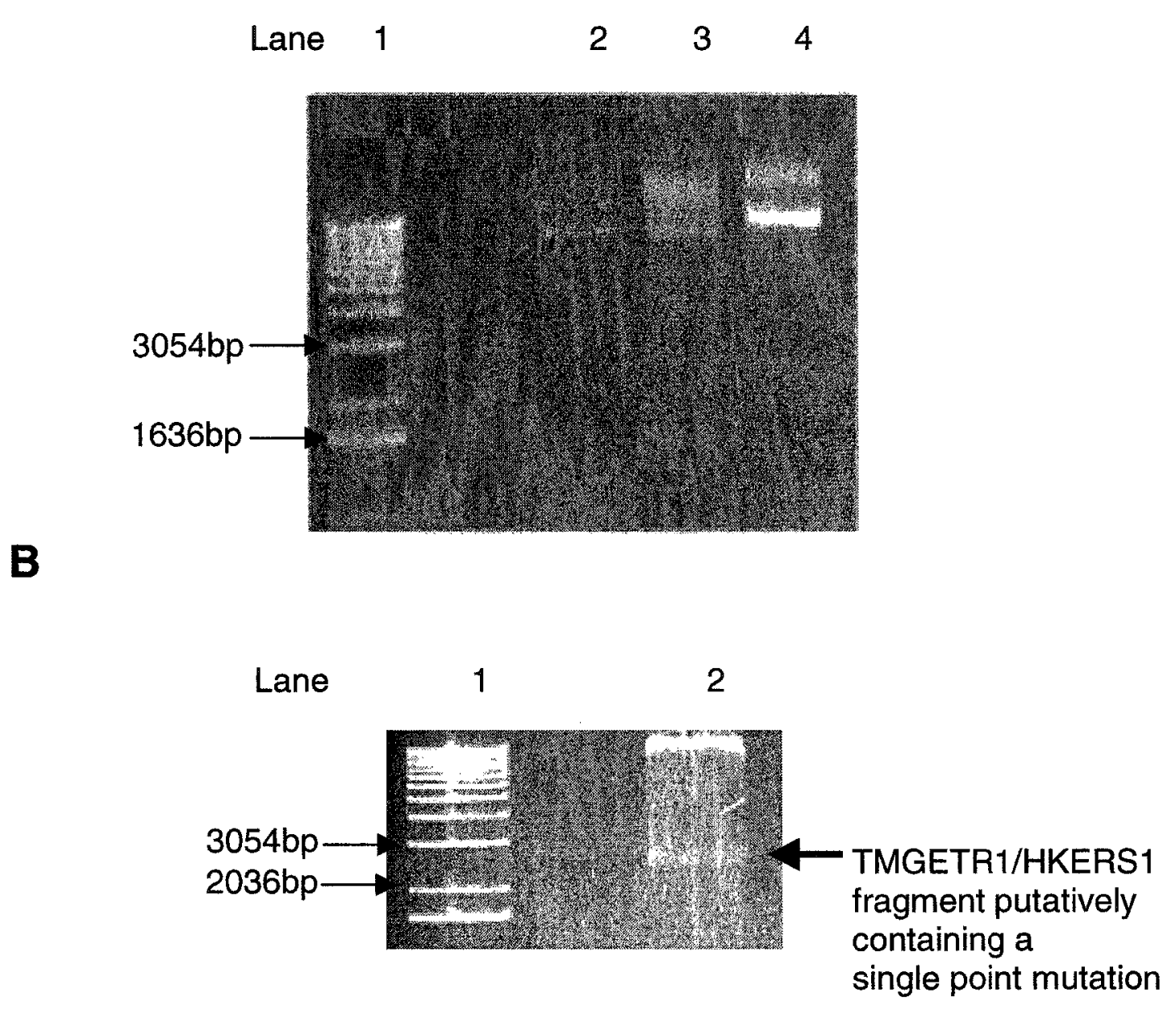

C

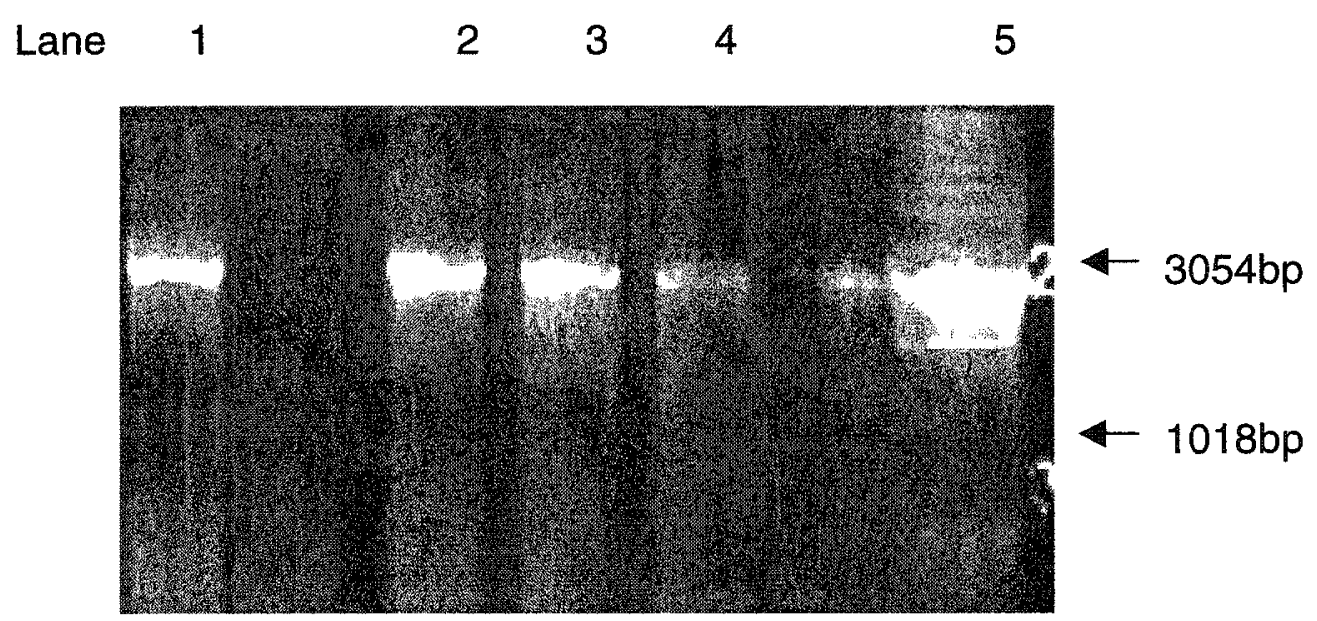




\subsection{Sequence Analysis of the Mutagenized Clones}

To confirm that the mutagenized plasmid contained the directed mutation, it was sequenced from the TMGETR1-fr primer (Table 2). The results of this analysis revealed a single nucleotide change, from guanosine to adenosine, at position 194 in the TMGETR1 coding sequence (Fig.17A). Therefore, the site-directed mutagenesis reaction was successful. Translation of this mutagenized construct introduces a $\mathrm{C}$ to $\mathrm{Y}$ substitution at codon 65 to mimic the alteration in etr1-1 (Hall et al., 1999) (Fig. 17B) 
Figure 17. Sequencing of the Mutagenized Plasmid

(A) The upper line in this sequencing comparison is the TMGETR1 CDNA fragment from nucleotide 1 to nucleotide 975 . The lower line shows the results obtained from the sequencing reaction. The nucleotide sequence that is highlighted in yellow makes up the forward primer that was used in the SiteDirected Mutagenesis reaction, with the exception of the guanosine, highlighted in red. In the forward primer, this guanosine was exchanged for an adenosine.

(B) The results show that the single point mutation created the cysteine to tyrosine change at amino acid 65. TGT codes for cysteine (C), while TAT codes for tyrosine $(Y)$. The sequence highlighted in yellow represents the forward primer that was used in the Site-Directed Mutagenesis reaction. The red highlighted letter ' $A$ ' within that sequence is the single base pair change that was made. The lower sequence represents the amino acid translation of the upper nucleotide sequence. The letters ATG, highlighted in blue, represent the beginning of the coding sequence for the ETR1 gene. 


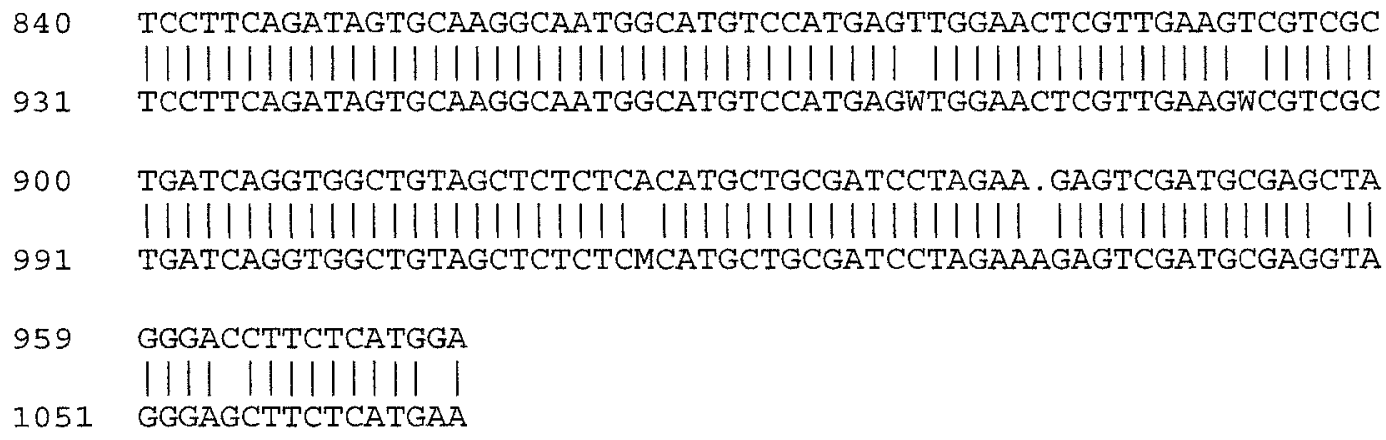

B

1 CGCGTCCCAAGATCCCAATTCTCCTCTTCTCCGATCAATTCTTCCCAAGTGTGTGTTTGT $\begin{array}{llllllllllllllllllllll} & \mathrm{R} & \mathrm{V} & \mathrm{P} & \mathrm{R} & \mathrm{S} & \mathrm{Q} & \mathrm{F} & \mathrm{S} & \mathrm{S} & \mathrm{S} & \mathrm{P} & \mathrm{I} & \mathrm{N} & \mathrm{S} & \mathrm{S} & \mathrm{Q} & \mathrm{V} & \mathrm{C} & \mathrm{V} & \mathrm{C}\end{array}$ 61 GTGAGAGAGGAACTATAGTGTAAAAAATTCATA GAAGTCTGCAATTGTATTGAACCG $\begin{array}{llllllllllllllllllllll}21 & V & R & E & E & L & * & C & K & K & F & I & M & E & V & C & N & C & I & E & P\end{array}$ 121

CAATGGCCAGCGGATGAATTGTTAATGAAATACCAATACATCTCCGATTTCTTCATTGCG $\begin{array}{llllllllllllllllllllll}41 & Q & W & P & A & D & E & L & I & M & K & Y & Q & Y & I & S & D & F & F & I & A\end{array}$ 181 ATTGCGTATTTTTCGATTCCTCTTGAGTTGATTTACTTTGTGAAGAAATCAGCCGTGTTT $\begin{array}{llllllllllllllllllllll}61 & I & A & Y & F & S & I & P & L & E & L & I & Y & F & V & K & K & S & A & V & F\end{array}$ 241 CCGTATAGATGGGTACTTGTTCAGTTTGGTGCTTTTATCGTTCTTTVTGGAGCAACTCAT

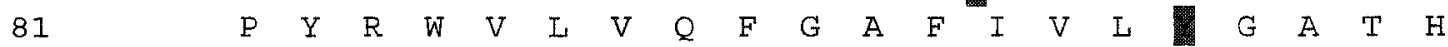
301 CTTATTAACTTATGGACTTTCACTACGCATTCGAGAACCGTGGCGCTTGTGATGACTACC $\begin{array}{lllllllllllllllllllll}101 & \mathrm{~L} & \mathrm{I} & \mathrm{N} & \mathrm{L} & \mathrm{W} & \mathrm{T} & \mathrm{F} & \mathrm{T} & \mathrm{T} & \mathrm{H} & \mathrm{S} & \mathrm{R} & \mathrm{T} & \mathrm{V} & \mathrm{A} & \mathrm{L} & \mathrm{V} & \mathrm{M} & \mathrm{T} & \mathrm{T}\end{array}$

361 GCGAAGTGTTAACCGCTGTTGTCTCGTGTGCTACTGCGTTGATGCTTGTTCATATTATTC $\begin{array}{lllllllllllllllllllll}121 & \mathrm{~A} & \mathrm{~K} & \mathrm{C} & * & \mathrm{P} & \mathrm{L} & \mathrm{L} & \mathrm{S} & \mathrm{R} & \mathrm{V} & \mathrm{L} & \mathrm{L} & \mathrm{R} & * & \mathrm{C} & \mathrm{L} & \mathrm{F} & \mathrm{I} & \mathrm{L} & \mathrm{F}\end{array}$

421 CTGACTCTTTTGAGTGTTAAGACTCGGGAGCTTTTCTTGAAAAATAAAGCTGCTGAGCTC $\begin{array}{lllllllllllllllllllll}141 & \mathrm{~L} & \mathrm{~T} & \mathrm{~L} & \mathrm{~L} & \mathrm{~S} & \mathrm{~V} & \mathrm{~K} & \mathrm{~T} & \mathrm{R} & \mathrm{E} & \mathrm{L} & \mathrm{F} & \mathrm{I} & \mathrm{K} & \mathrm{N} & \mathrm{K} & \mathrm{A} & \mathrm{A} & \mathrm{E} & \mathrm{L}\end{array}$ 481 GATAGAGAAATGGGATTGATTCGAACTCAGGAAGAAACCGGAAGCATGTGAGAATGTTGA $\begin{array}{llllllllllllllllllllll} & 161 & D & R & E & M & G & L & I & R & T & Q & E & E & T & G & S & M & * & E & C & *\end{array}$ 
541

CTCATGAGATTAGAAGCACTTTAGATAGACATACTATTTTAAAGACTACACTTGTTGAGC

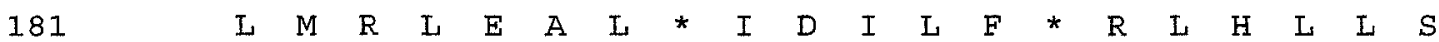

601

TTGGTAGGACATTAGCTTTGGAGGAGTGTGCATTGTGGATGCCTACTAGAACTGGGTTAG

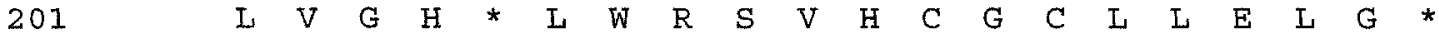

661

AGCTACAGCTTTCTTATACACTTCGTCATCMACATCCCGTGGAGTATACGGTTCCTATTC

$\begin{array}{lllllllllllllllllllll}221 & S & Y & S & F & L & I & H & F & V & I & X & I & P & W & S & I & R & F & L & F\end{array}$

721

AATTACCGGTGATTAACCAAGTGTTTGGTACTAGTAGGGCTGTAAAAATATCTCCTAATT

$\begin{array}{lllllllllllllllllllll}241 & N & Y & R & * & L & T & K & C & L & V & L & V & G & L & * & K & Y & L & L & I\end{array}$

781

CTCCTGTGGCTAGGTTGAGACCTGTTTCTGGGAAATATATGCTAGGGGAGGTGGTCGCTG

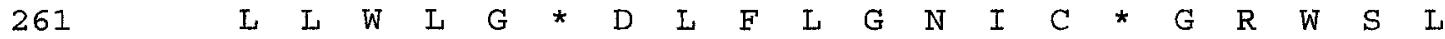

841

TGAGGGTTCCGCTTCTCCACCTTTCTAATTTTCAGA'TAATGACTGGCCTGAGCYTTCAA

$\begin{array}{llllllllllllllllllllll}281 & * & G & F & R & F & S & T & F & L & I & F & R & L & M & T & G & L & S & X & Q\end{array}$

901.

CAAAGAGATATGCTTGATGGTTTTGATGCTTCCTTCAGATAGTGCAAGGCAATGGCATGT

$\begin{array}{llllllllllllllllllllll}301 & Q & R & D & M & L & D & G & F & D & A & S & F & R & * & C & K & A & M & A & C\end{array}$

961

CCATGAGWTGGAACTCGTTGAAGWCGTCGCTGATCAGGTGGCTGTAGCTCTCTCMCATGC

321

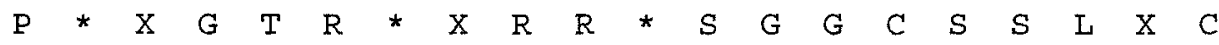

1021

TGCGATCCTAGAAAGAGTCGATGCGAGGTAGGGAGCTTCTCATGAATATATCTATATAT

341

$\begin{array}{llllllllllllllllllllllll}C & D & P & R & K & S & R & C & E & V & G & S & F & S & * & I & Y & I & Y\end{array}$ 


\subsection{Transformation with the pCam - TMGETR1/ERS1 Constructs}

The ultimate purpose of this project was to test whether or not the expression of the tmgetr1-1/hkers1 chimera would result in phenotypic changes in wild-type plants when they were transformed with this construct. Using the "floral dip" transformation protocol (Clough et al., 1998), wild-type Arabidopsis thaliana ecotype Columbia plants were transformed with the following two, pCambia 1301 constructs: 1) containing the TMGETR1/HKERS1 chimeric DNA, and; 2) containing the tmgetr1-1/hkers1 chimeric DNA with a single base pair change from adenine to guanine at position 194 within the TMGETR1 coding sequence. Transformed plants from both constructs were obtained.

Wild-type plants were transformed with the two chimeric constructs and the mature seeds were harvested approximately 4 weeks later. The seeds were then sterilized and the transformants were selected on MS media containing hygromycin (section 2.14). Transformants were resistant to hygromycin on MS plates containing this antibiotic while non-transformed plants died on this medium. The $T_{1}$ generation of transformants was moved to soil and their phenotype was observed and recorded.

The $T_{1}$ generation of transformants, containing the tmgetr1-1/hkers 1 chimera, demonstrated a delay in bolting as compared to the $T_{2}$ generation of TMGETR1/HKERS1 transformants as well to the wild-type plants. Wild-type plants grown under these conditions $\left(22^{\circ} \mathrm{C}, 16\right.$ hours of light, 8 hours of dark) normally begin to bolt after 4 weeks (Boyes et al., 2001). Thirty-two days after 
germination, the TMGETR1/HKERS1 transformants and the wild-type plants (Fig. $18 \mathrm{G}$ and $18 \mathrm{H}$ ) were at a similar stage in the formation of the stem, while some of the tmgetr1-1/hkers 1 transformants had not yet begun to bolt (Fig. $18 \mathrm{~F})$.

The tmgetr1-1/hkers 1 transformants demonstrated dwarf and semidwarf phenotypes. At maturity, these transformants only reached maximum heights of up to $160 \mathrm{~mm}$ while their wild-type counterparts reached heights of up to approximately $350 \mathrm{~mm}$ (Fig. 18J). At maturity, these transformants were found to possess fewer basal leaves, in some cases as few as six were discovered, whereas their wild-type counterparts possessed anywhere from 12 to 15 basal leaves. The tmgetr1-1/hkers 1 transformants were also found to posses a significantly smaller rosette diameter, as small as $10 \mathrm{~mm}$ at plant maturity, whereas the rosette diameter of wild-type plants reached approximately $70 \mathrm{~mm}$. After 48 days of growth, wild-type plants grown under these conditions $\left(22^{\circ} \mathrm{C}, 16\right.$ hours of light, 8 hours of dark) can be expected to be fully mature (Boyes et al., 2001), however, many tmgetr1-1/hkers 1 transformants had rosette diameters as small as $4 \mathrm{~mm}$ and some of them had not yet begun to bolt ( Figs. $18 \mathrm{~K}, \mathrm{~L}, \mathrm{M}, \mathrm{N}, \mathrm{O}$ and Table 4).

To confirm that the wild-type plants had been transformed with the TMGETR1/HKERS1 chimera, leaf cuttings from putative transformants were obtained from these plants and were inserted vertically, wounded side downward, into solid MS media containing $0.5 \mathrm{mg} / \mathrm{L}$ 6-benzylaminopurine and 100mg/L hygromycin (Wang and Waterhouse, 1997). The leaves of the 
transformants should remain green and should appear healthy for up to three weeks when placed on this media. It was found that the leaves from nontransformed, control plants turned brown and withered after two days on this media. The leaves from transformed plants remained green and healthy for over 2 weeks (Fig. 18E). 
Figure 18. Various TMGETR1/HKERS1 and tmgetr1-1/hkers1 Transformants (A) This image shows wild type plants grown on MS media without hygromycin after 2 weeks. Note that the leaves appear flat and that they have a healthy green appearance.

(B) This image shows potential transformants on MS with hygromycin at a concentration of $30 \mathrm{mg} / \mathrm{L}$ after 10 days. Note that the leaves have curved into an abnormal spherical shape and that the leaves appear very glossy.

(C) This image shows potential transformants grown on hygromycin at a concentration of $30 \mathrm{mg} / \mathrm{L}$ after 16 days. 1. (arrow) The wild type plants appear yellowish and unhealthy. 2. (arrow) The tmgetr1-1/hkers1 transformant appears green and healthy.

(D) Four week-old TMGETR1/HKERS1 transformant. The appearance of their leaves was different from that of their wild-type counterparts when grown under identical conditions, taking on a reddish appearance, indicative of stress.

(E) The four leaves on the left from transformed plants are green and healthy after 2 weeks on this selection medium. The two leaves from wild-type plants, on the right, are brown and dry, due to the presence of hygromycin.

$(F),(G)$ and $(H)$ This is a comparison of 32 Day-old plants, including a tmgetr1-1/hkers 1 transformant, TMGETR1/HKERS1 transformants and wildtype Arabidopsis thaliana ecotype Columbia, respectively. The TMGETR1/HKERS1 transformants and the wild-type plants began to bolt at the same time and the stalk heights were approximately the same heights on 

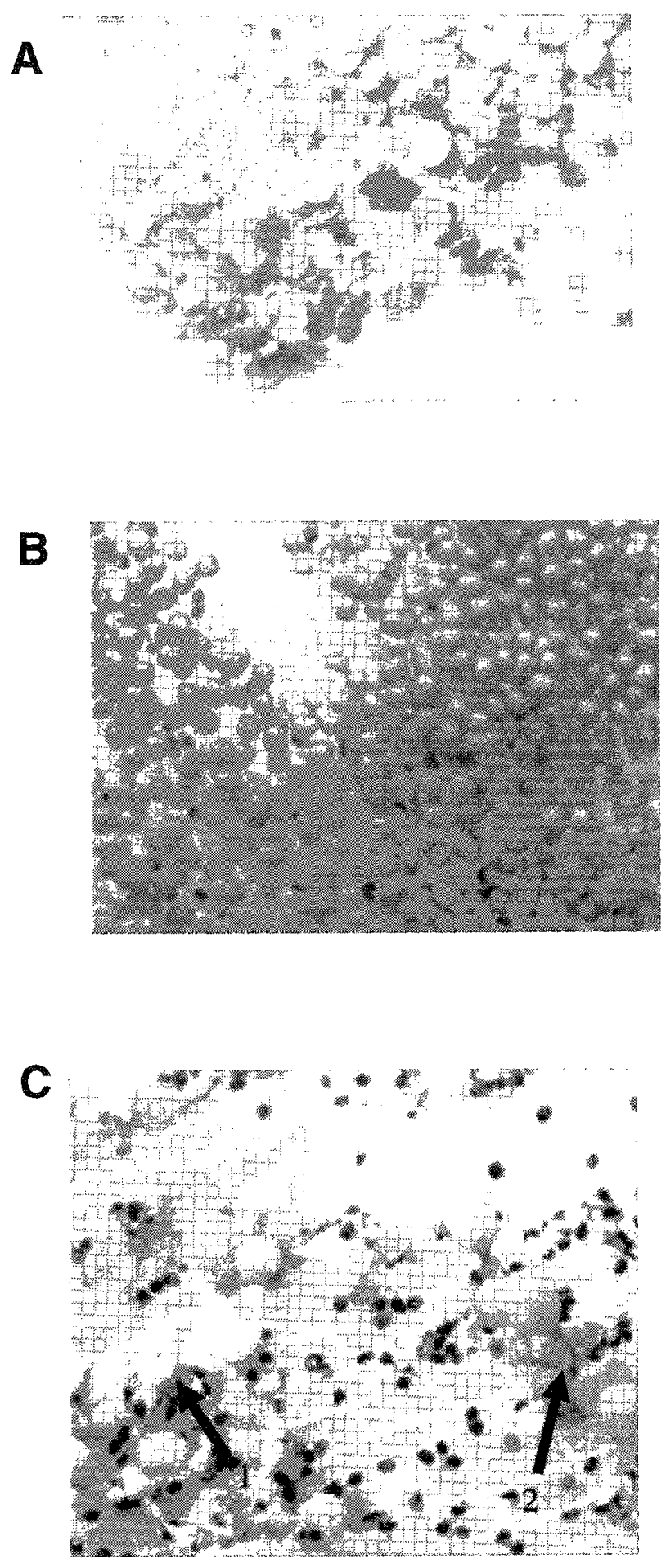


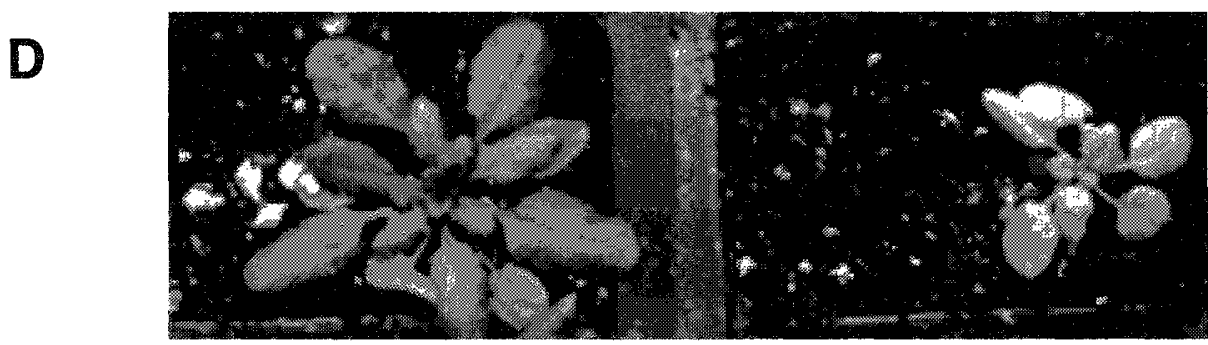

transformed plant (TMGETR1/

HKERS1)
Wild-type Arabidopsis

thaliana

ecotype Columbia

\section{$\mathbf{E}$}

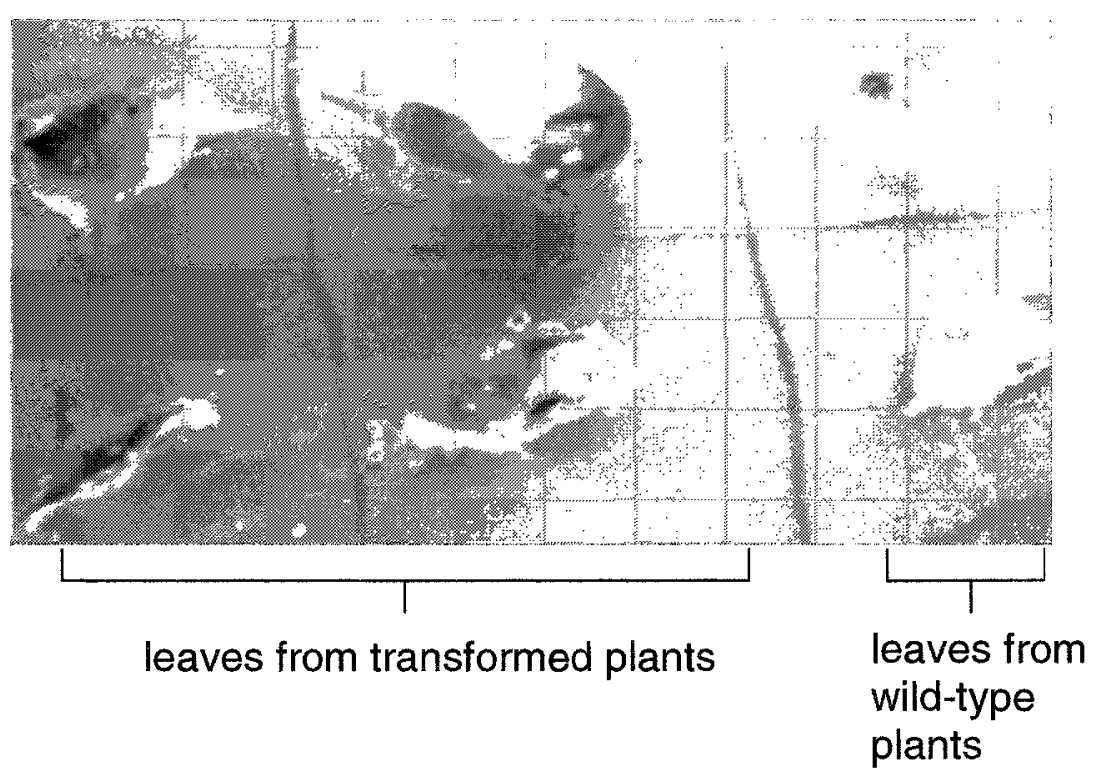


F

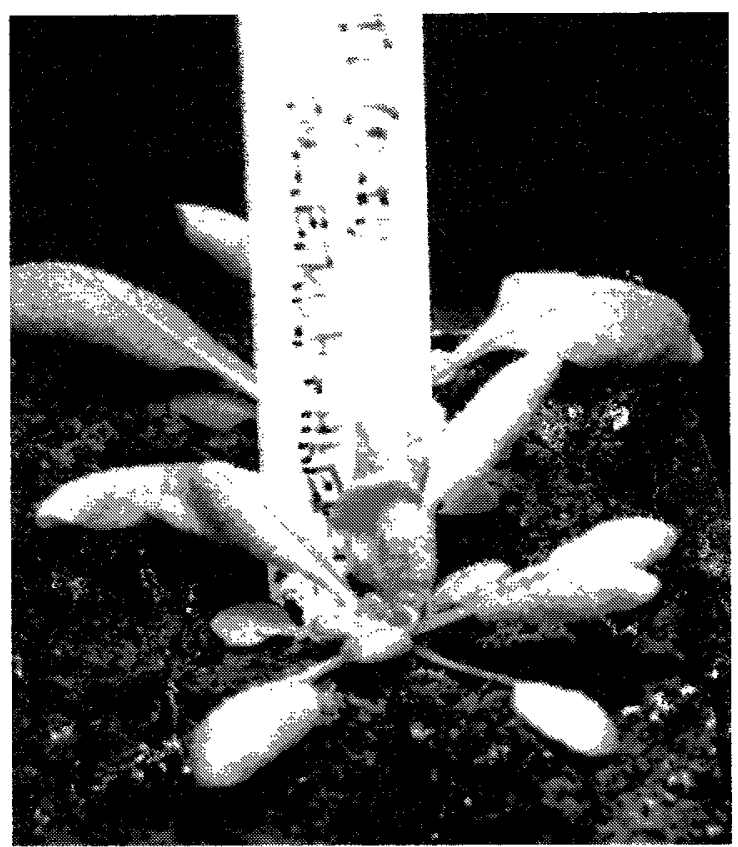

tmgetr1-1/hkers 1 transformant (32 days after germination)
G

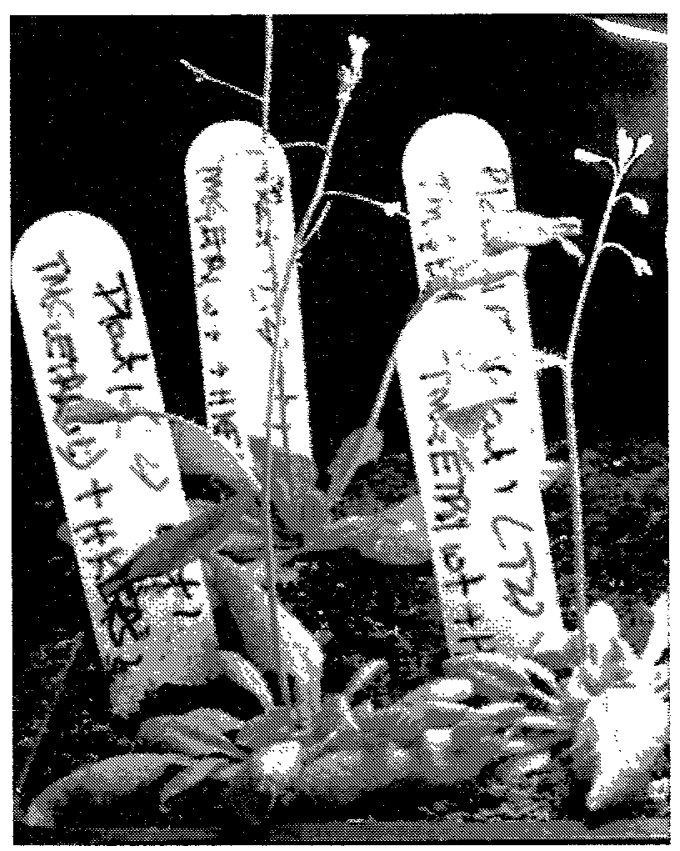

TMGETR1/HKERS1

transformants ( 32 days after germination)
H

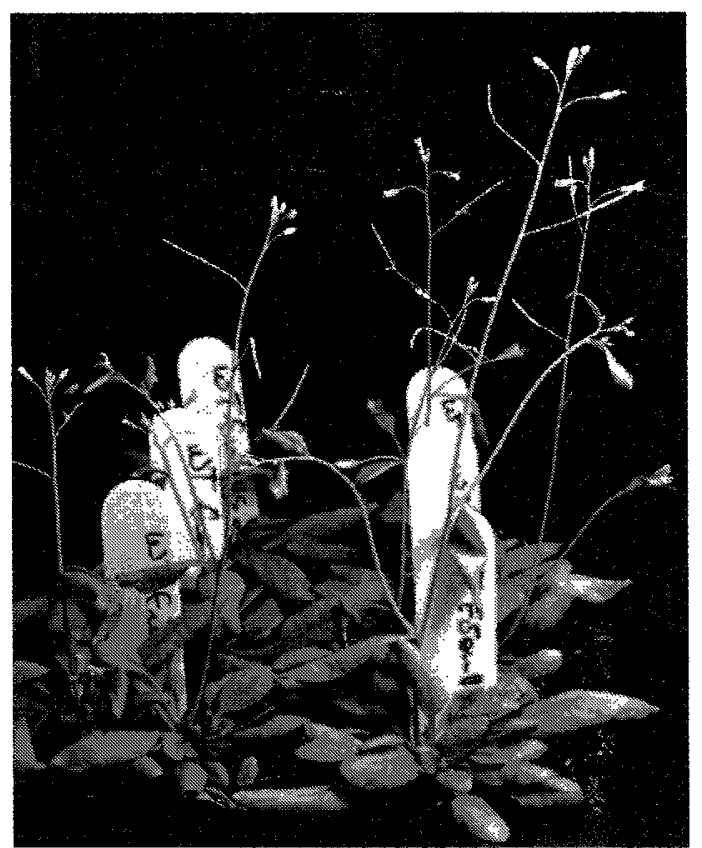

Wild-type Arabidopsis thaliana ecotype Columbia (32 days after germination) 
both. On the other hand, the tmgetr $1-1 /$ hkers 1 mutants only began to bolt ten days after the other plants.

(I) This is a comparison of tmgetr1-1/hkers 1 transformants and wild-type plants, both 48 days old. The tmgetr1-1/hkers 1 transformants, 1 and 2 (arrows), are much more reduced in stature, their rosette diameter is much smaller and the leaves are smaller than wild type plants. 3. (arrow) Wild type plants.

(J) This is a comparison of mature wild-type plants and mature tmgetr11/hkers 1 transformants, both 84 days old. This picture demonstrates that, even at maturity, the transformants are reduced in size and stature. 1. (arrow) Wild type plant. 2. (arrow) tmgetr1-1/hkers 1 transformant. (K), (L), (M) and (N) These pictures depict the dwarf and semi-dwarf phenotypes of various tmgetr1-1/hkers 1 transformants, all 48 days-old. The rosette diameters of these transformants ranged from $8 \mathrm{~mm}$ to $30 \mathrm{~mm}$. The rosette size of wild-type Arabidopsis thaliana ecotype Columbia plants at maturity is approximately 70 when grown under these conditions $\left(22^{\circ} \mathrm{C}, 16\right.$ hours of light, 8 hours of dark). Only some of these transformants have bolted, whereas their wild-type counterparts have a stem approximately 350mm tall (Fig. 18J).

(O) Bar Graph Comparing the Rosette Diameters of Various tmgetr1-1/hkers1 transformants (48 days after germination). All of these transformants have rosette diameters that are reduced in size compared to that of their wild-type counterparts. (P) Bar Graph Comparing the Stalk Heights of Various 48 day- 

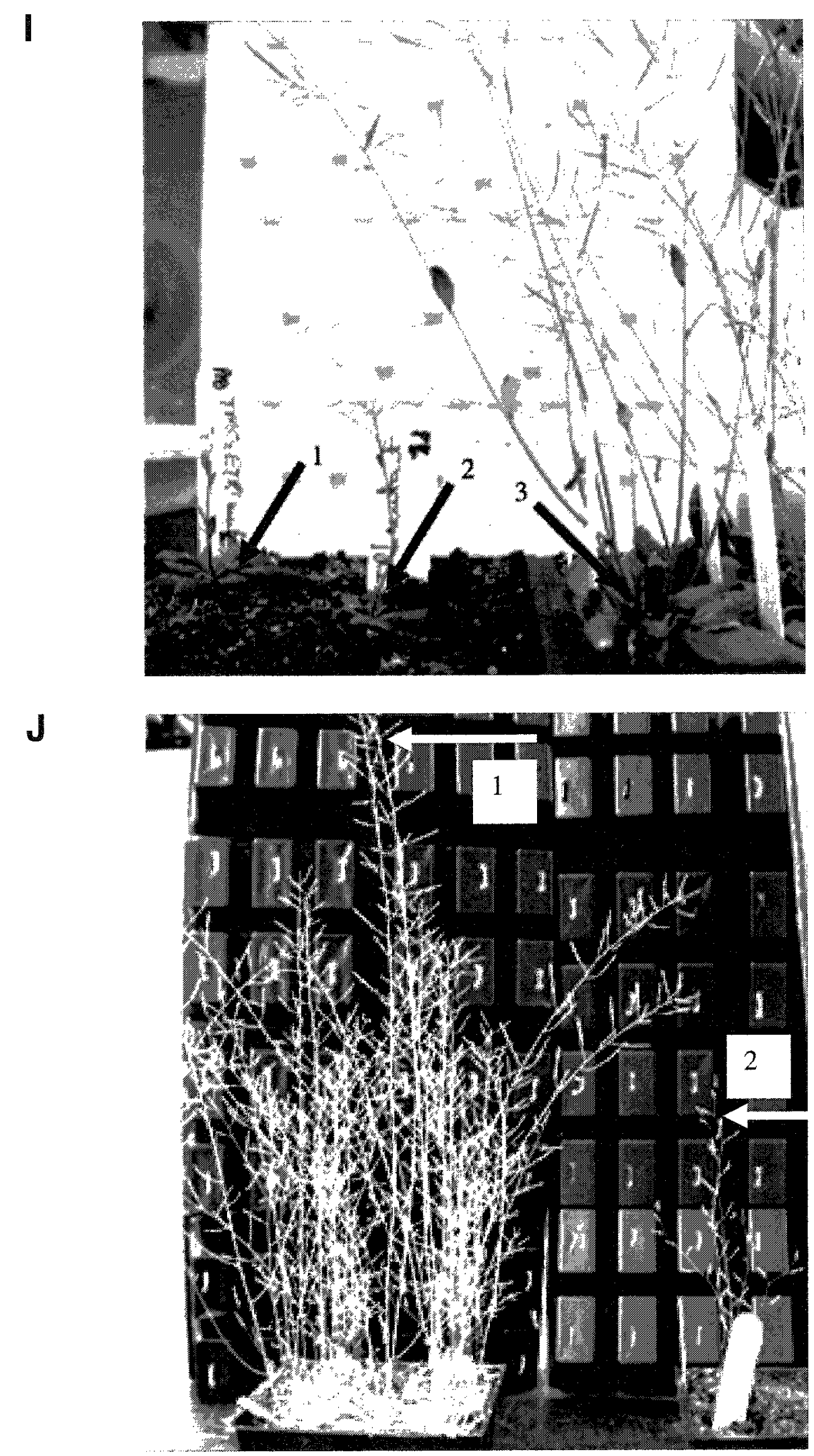
old tmgetr1-1/hkers 1 transformants. These transformants bolted much later than their wild-type counterparts. 


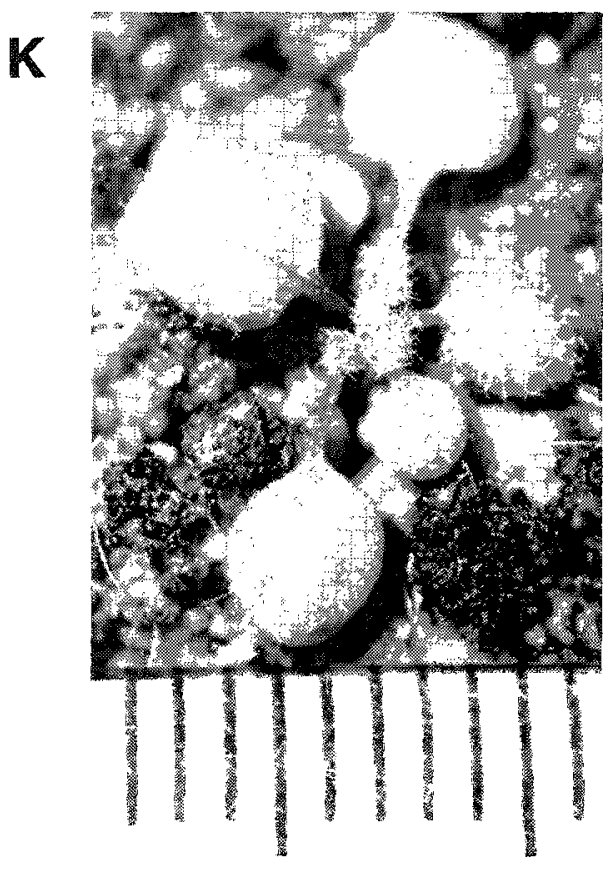

Rosette Diameter $=$ $8 \mathrm{~mm}$

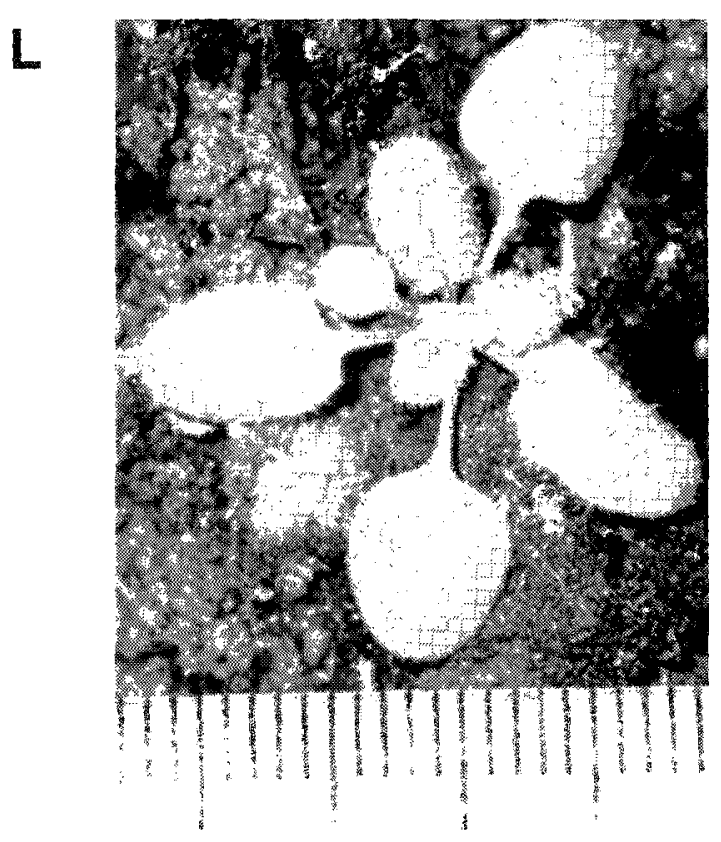

Rosette Diameter $=$ $20 \mathrm{~mm}$
M

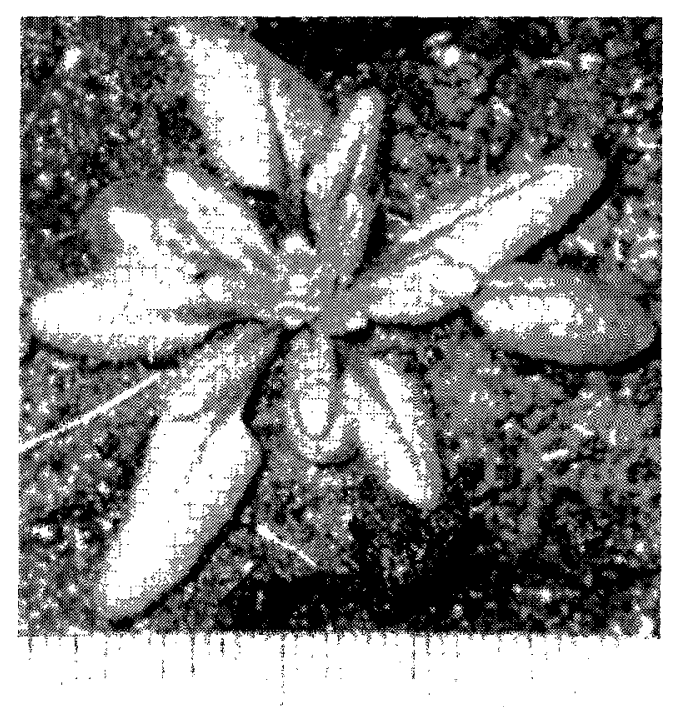

Rosette Diameter $=43 \mathrm{~mm}$
$N$

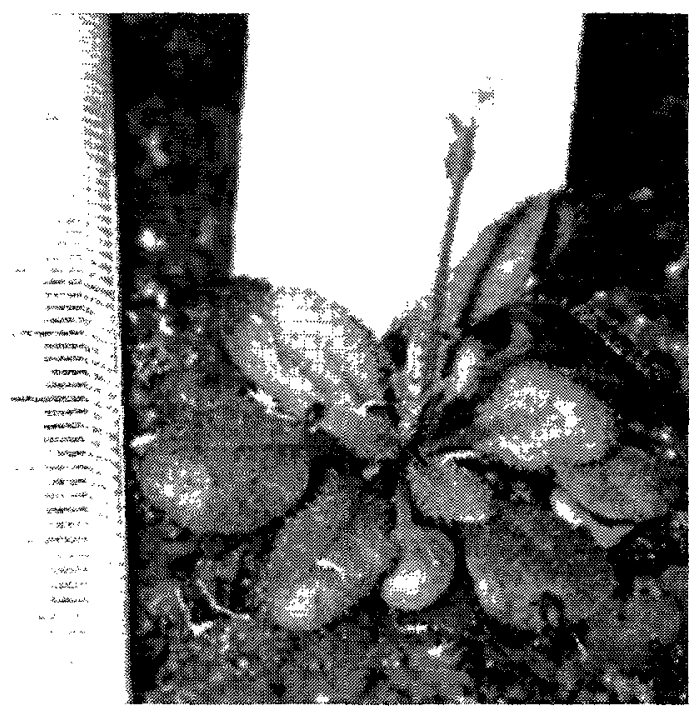

Rosette Diameter $=18 \mathrm{~mm}$ 
0

Comparison of the Rosette Diameters of Various tmgetr1-1/hkers1 Transformants (48 days after germination)

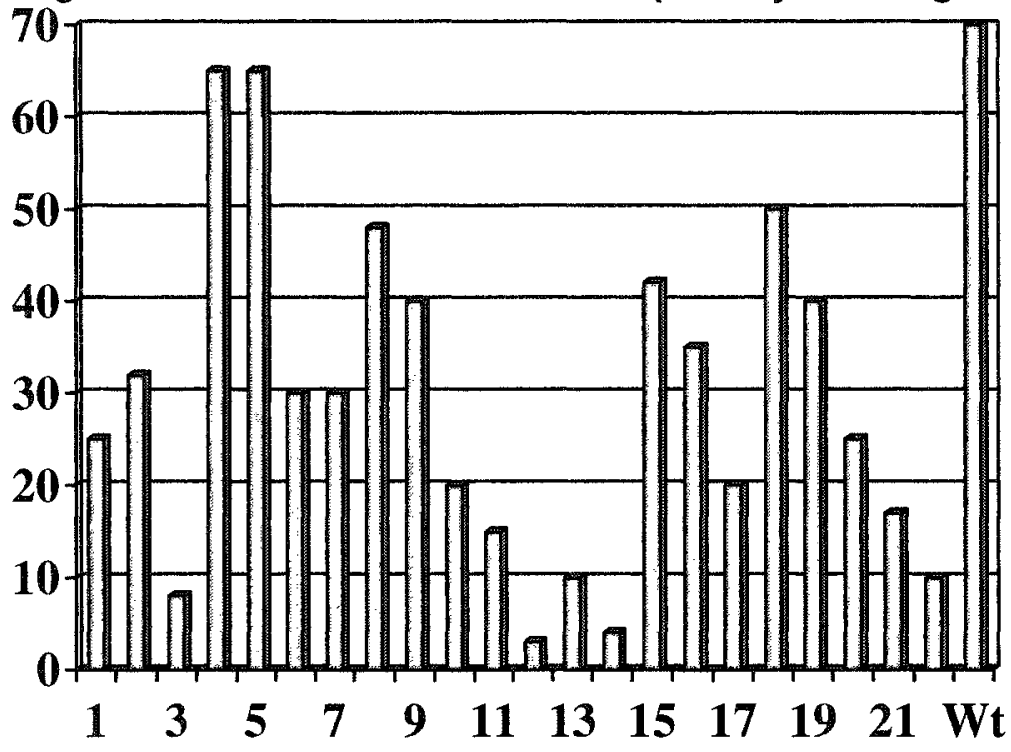

$(\mathrm{mm})$

tmgetr1-1/hkers1 transformant

P

Comparison of the Stalk Heights of Various tmgetr1-

1/hkers1 Transformants (48 davs after germination)

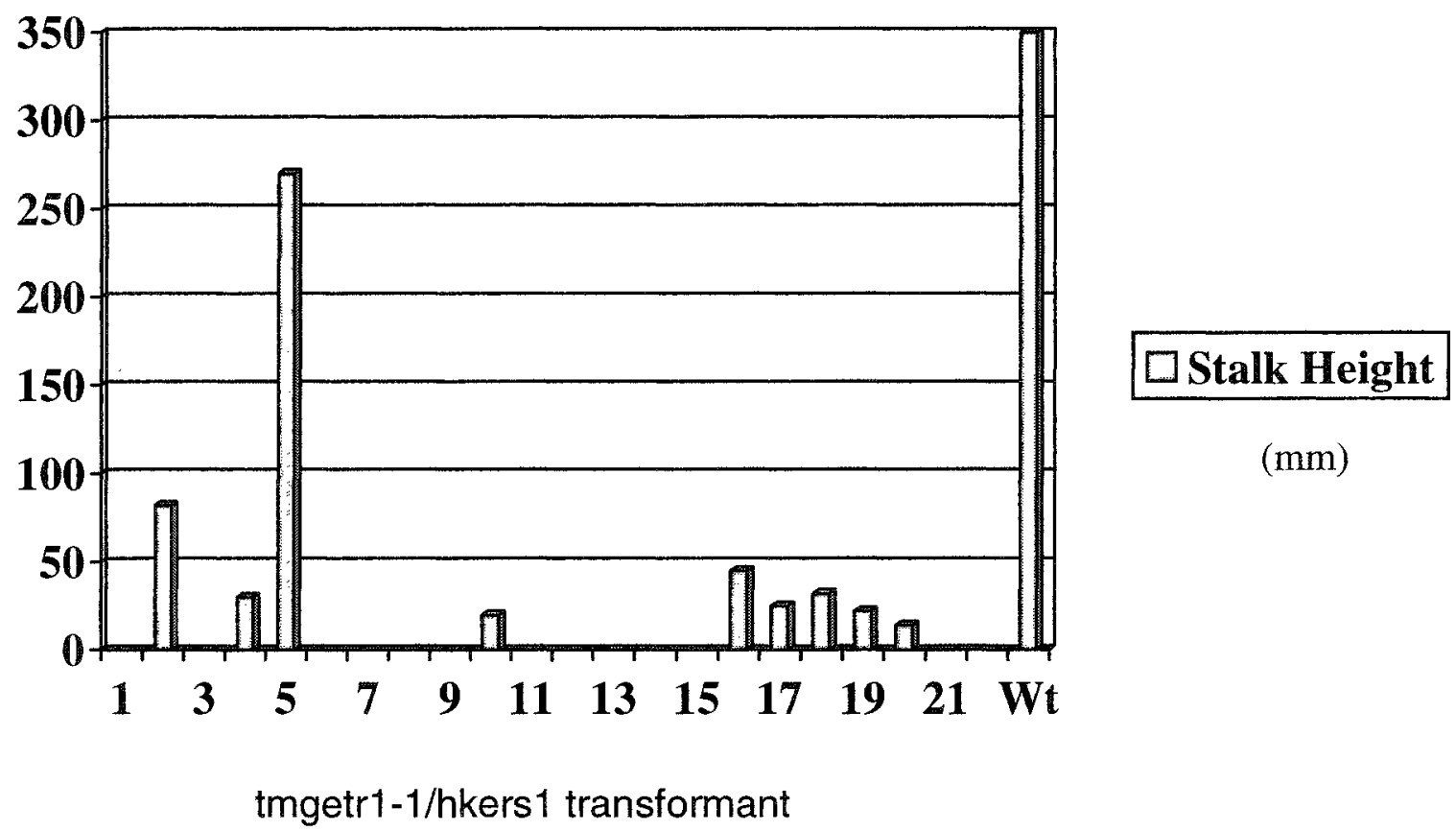


Table 4. Comparison of the Rosette Sizes and Stalk Heights of the tmgetr1-1 Transformants with that of a Wild-type Plant (ecotype Columbia), Both 48 Days Old

\begin{tabular}{|c|c|c|}
\hline $\begin{array}{c}\text { Transformant } \\
\text { (tmgetr1-1/hkers1) }\end{array}$ & $\begin{array}{l}\text { Rosette Diameter } \\
\qquad(\mathrm{mm})\end{array}$ & $\begin{array}{l}\text { Stalk Height } \\
\qquad(\mathrm{mm})\end{array}$ \\
\hline 1 & 25 & none \\
\hline 2 & 32 & 82 \\
\hline 3 & 8 & none \\
\hline 4 & 65 & 30 \\
\hline 5 & 30 & none \\
\hline 6 & 30 & none \\
\hline 7 & 48 & none \\
\hline 8 & 40 & none \\
\hline 9 & 20 & 20 \\
\hline 10 & 15 & none \\
\hline 11 & 3 & none \\
\hline 12 & 10 & none \\
\hline 13 & 4 & none \\
\hline 14 & 42 & none \\
\hline 15 & 35 & 45 \\
\hline 16 & 20 & 25 \\
\hline 17 & 50 & 32 \\
\hline 18 & 40 & 22 \\
\hline 19 & 25 & 14 \\
\hline 20 & 10 & none \\
\hline Control (Wt) & 70 & 350 \\
\hline
\end{tabular}




\section{Discussion}

\subsection{Ethylene Signal Transduction}

Etiolated Arabidopsis thaliana seedlings treated with ethylene exhibit shortening and thickening of the hypocotyls and roots and an exaggeration of the apical hook (Gamble et al., 2002). This mimics the response observed under natural conditions when seedlings are emerging from the soil where they are subjected to physical stress that stimulates ethylene production. This ethylene production causes an exaggerated curvature of the apical hook to protect the apical structure from damage as the seedling penetrates the soil (McGrath and Ecker, 1998). Since ethylene is involved in the early stages of seedling growth, it is not difficult to imagine that ethylene is also involved in seed germination. In fact, the breakage of seed dormancy through external stimulants appears to be mediated by endogenous ethylene, since the inhibition of the action of ethylene in dormant seeds completely blocks germination (Machabee and Saini, 1991).

In wild-type Arabidopsis, CTR1 and the 5 ethylene receptors work together to negatively regulate the ethylene response pathway. Therefore, when ethylene is present, it inactivates the ethylene receptors and the ethylene responses are observed (Bleeker and Kende, 2000). A nucleotide change from adenine to guanine within the ETR1 coding sequence (Hall et al., 1999) results in the etr1-1 mutant allele. When this allele is expressed in Arabidopsis it results in a dominant, gain of function mutation that locks the ethylene receptor into an active signaling state (Zhoa et al., 2002). This 
mutant ethylene receptor binds $80 \%$ less ethylene than the wild-type receptor (Ecker, 1995). It represses the ethylene response in etiolated seedlings even in the presence of ethylene (Gamble et al., 2002). Moreover, ethylene insensitive mutants of Arabidopsis, including etr1-1 (Ecker, 1995), show poor germination in relation to wild-type plants (Leon-Kloosterziel et al., 1996).

\subsection{The Forward Genetics Approach}

The mutation in the etr1-1 allele is well characterized and its resultant phenotype has been studied extensively (Chang et al., 1993). Gain of function mutations in ETR1 and ERS1 genes are known to exhibit the ethylene insensitive response (Hua et al., 1995; Chang et al., 1993) and only those two ethylene receptors contain the conserved histidine kinase domain (Wang et al., 2003), therefore it is a natural progression of the study of these two genes to investigate the roles of the histidine kinase domains within these proteins.

The approach selected for detecting a unique role for either receptor was to exchange the histidine kinase domains of ETR1 and ERS1. A chimeric gene composed of the ethylene binding and GAF domains of etr1-1 and the histidine kinase domain of ERS1 was introduced into a wild-type Arabidopsis strain to assess ethylene sensitivity and seed dormancy. If the phenotype of the transformant is similar to that of the etr1-1 mutant, it could be concluded that the histidine kinase domain of ERS1 performs that same function of that of its counterpart in ETR1. 
This forward genetics approach to acquiring the desired mutation within the transmembrane-encoding region of ETR1 was through site-directed mutagenesis. The cloned chimeric gene composed of the transmembrane and GAF domain encoding regions of ETR1 and the histidine kinase domain encoding region of ERS1 was altered by site-directed mutagenesis. The single base pair change within the transmembrane domain of ETR1 was chosen to mimic the mutation found in the etr1-1 allele.

The etr1-1 mutant allele was first discovered through mutagenizing a large number of wild-type Arabidopsis seeds with the chemical mutagen, ethyl methane sulfonate (EMS) (Chang et al., 1993). However, since it is a dominant ethylene insensitive mutation, this allele can be introduced into wildtype plants by means of the "flower dip" protocol (Katavic et al., 1994) and the resultant transformants will be ethylene insensitive (Gamble et al., 2002). Therefore, when the chimeric gene composed of TMGETR1 and HKERS1 is introduced into wild type plants, we expect this mutation to be dominant even when it is present in a single copy. This is believed to be the result of dimerization between functional and non-functional receptor ETR1 subunits (Gamble et al., 2002). Therefore, this dominant phenotype makes it very convenient to discover the resultant phenotype of the chimeric allele within even the $T_{1}$ generation of transformants that are usually heterozygous for the mutant allele.

The goal of the forward genetics approach in this project was to use the generated mutants to help identify the roles of the genes, ETR1 and 
ERS1 within the ethylene signal transduction pathway (Ostergaard and Yanofsky, 2004). Through performing detailed phenotypic analysis of these mutants, including the ethylene insensitivity phenotype and the seed dormancy phenotype, we can better understand the biochemical mechanisms underlying this pathway.

\subsection{Cloning Strategy}

The 1103 bp transmembrane and GAF encoding domains of ETR1 that were part of the chimeric gene construct consisted of cDNA. On the other hand, the $1217 \mathrm{bp}$ histidine kinase encoding domain of ERS1 that was also part of that chimeric gene consisted of genomic DNA. The reason for this mixture of cDNA and genomic DNA fragments was partially by chance. The entire construct was initially meant to be composed of entirely CDNA, however it was this combination of genomic and CDNA that happened to generate a chimeric gene consisting of these two combinations of DNA.

The advantage of having a chimeric gene composed entirely of cDNA would be that the entire recombinant plasmid would be smaller. Therefore, it would be easier to perform the necessary transformations of E.coli and Agrobacterium (Sambrook and Russell, 2001). Also, if the chimeric gene were composed entirely of cDNA, it would be easy to digest the chimeric gene from the plant transformation vector and ligate it into a bacterial expression vector. This gene could only be expressed in bacteria if it was composed entirely of cDNA because bacteria lack the splicing machinery to remove the introns 
from genomic DNA (Sambrook and Russell, 2001). Therefore, my chimeric gene would not be useful in a bacterial expression vector because it is composed of both cDNA and genomic DNA.

When the primary transcript is produced in the nucleus, it is processed before being transported to the cytoplasm. In eukaryotes, a splicing reaction that removes internal regions of the RNA transcript, termed introns, occurs. These introns are removed and the coding regions, termed exons are brought together to form the mRNA (Griffiths et al., 2000). One advantage of having a chimeric gene composed of both cDNA and genomic DNA is that, in the future, the expression of this gene could be determined to assess if this combination of DNA is viable. Perhaps, with this combination of genomic DNA and CDNA, the splicing events that necessarily occur within the nucleus will be inhibited. The expression level could be determined at the mRNA level through Northern blots or at the post-translational level through immunoblotting, since antibodies currently exist for the ETR1 protein (Gamble et al., 2002). The expression of this protein may be of interest to other researchers who have chimeric genes composed of both cDNA and genomic DNA.

An interesting observation was made when isolating the various ETR1 and ERS1 fragments by RT-PCR amplification. Total RNA was isolated from wild-type Arabidopsis plants and it was then used as a template for first strand CDNA synthesis. It was discovered that when the CDNA from wild-type plants was used as the template in an RT-PCR, the TMGETR1, TMGERS1, 
HKETR1 and HKERS1 amplification products corresponded to the lengths expected of spliced mRNA. On the other hand, when cDNA originating from either the ers1 or the etr1-1 mutant plants was used as template in an RTPCR reaction, the TMGETR1, TMGERS1, HKETR1 and HKERS1 amplification products corresponded to the lengths expected from genomic DNA or unspliced transcripts. Subsequent PCR experiments to determine if the RNA that originated from the mutant plants was contaminated with genomic DNA were ambiguous.

The most obvious reason for the above finding could be that there was simply genomic DNA contamination in the RNA samples from the mutant plants that were used to generate the CDNA. Since the ers 1 and etr1 genes are expressed at very low levels, even a small amount of contaminating genomic DNA could be amplified during PCR amplification, instead of the corresponding CDNA. In addition, there is evidence that the expression of the ethylene receptor mRNA is inducible (Hua et al., 1998). It is possible that the etr1 and ers 1 genes are not induced to the same levels in the mutant strains compared to the wild-type strains. Another possible explanation may be that the introns were not spliced out of the original ETR1 and ERS1 transcripts as efficiently in the mutant strains.

To facilitate directional cloning, an Apal restriction site was added onto the 3' end of the TMGETR1 fragment as well as onto the 5' end of the HKERS 1 fragment. This cloning procedure introduced two additional codons specifying glycine and proline at the TMGETR1/HKERS1 junction. Glycine 
may not affect the overall functionality of the chimeric ethylene receptor protein because there is a large degree of conformational flexibility with this amino acid. It contains hydrogen on its side chain, rather than carbon, as is the case with all other amino acids (Bett et al., 2003). Therefore it can reside in parts of the protein structure that is impossible for all other amino acids.

Proline may affect the overall functionality of the chimeric ethylene receptor protein. It is the only amino acid whose side chain is connected to the protein backbone twice, forming a five-membered nitrogen-containing ring. This means that proline is unable to occupy many of the side-chain conformations that are easily adopted by all other amino acids (Bett et al., 2003). Therefore, proline is often found in many tight turns in protein structures, such as where a polypeptide chain must change directions (Bett et al., 2003). These characteristics of proline may not allow the chimeric ethylene receptor to form the correct three-dimensional conformation in order to be active. Therefore, further testing of this protein must be performed to determine whether or not it is functional.

When site-directed mutatgenesis was performed on the TMGETR1/HKERS1 construct in order to make a single base pair change within the transmembrane domain-encoding region of ETR1, the effect was to replace a cysteine with a tyrosine in the resulting protein. This cysteine residue likely coordinates the copper ion that is present within the ethylene receptor to mediate ethylene binding (Hall et al., 1999). When cysteine is replaced by tyrosine in the ETR1 protein it results in the etr1-1 gain-of- 
function mutant, because it prevents not only the copper from binding, but it also locks the ethylene receptor into an active signaling conformation such that exists in the absence of ethylene (Zhoa et al., 2002).

The sulfhydrl side-chain on cysteine is excellent for binding metals (Betts et al., 2003), thus explaining its role in binding the copper ion in the ethylene receptor (Hall et al., 1999). Therefore, when cysteine is exchanged for tyrosine, in the above example, the binding of copper ceases since tyrosine is a hydrophobic amino acid that tends to be buried within a hydrophobic region of a protein (Betts et al., 2003).

Since there is normally such a low expression level of the ethylene receptors (Chang et al., 1993) it is unclear whether or not it is biologically valid to drive the expression of the chimeric ethylene receptor gene within the pCambia 1301 vector by means of a high expression, CaMV 35S promoter (cambia.org). In the research performed by Gamble et al. (2002), the expression of the etr1-1 gene was driven by the ETR1 promoter and was able to confer the ethylene insensitive response when transformed into wild-type plants. The ethylene receptors sense a low concentration of ethylene (Gamble et al., 2002); therefore high expression of this chimeric gene may make any of the phenotypic observations of the resultant transformants ambiguous. The high expression of this one chimeric gene may make it difficult to determine the roles of the other ethylene receptors within the plant. It may also cause the exaggerated expression of other stress related proteins for example. 
The chimeric gene, tmgetr1-1/hkers 1 was put into the pCambia 1301 vector, driven by the CaMV 35 S promoter because we wanted the chimeric gene to be highly expressed (www.cambia.org). When this occurs, the resulting protein from the chimeric ethylene receptor gene would be by far the most prevalent of the ethylene receptors, since ethylene receptors are normally transcribed to a low degree (Chang et al., 1993). It is believed that the resulting phenoptype could then be ascribed to the chimeric gene. This would give us an indication of the degree of ethylene sensitivity of the transformant.

The growth of the tmgetr1-1/hkers 1 transformants was severely stunted. At 44 days old the rosette sizes of these transformants ranged in size from $8 \mathrm{~mm}$ to $50 \mathrm{~mm}$, while that of their wild-type counterparts was approximately $70 \mathrm{~mm}$ (Table 4). Also, at 44 days old, many of these transformants had not yet begun to bolt. On the other hand, wild-type plants grown under these conditions normally show the first flower bud, the first sign of bolting, at around day 23 (Boyes et al., 2001). The leaf sizes of many of these transformants were also severely stunted. In extreme cases, the leaves were as small as $2 \mathrm{~mm}$ in length and width. On the other hand, a wild-type plant would have ten to fifteen leaves, averaging $3 \mathrm{~cm}$ in length and $1 \mathrm{~cm}$ in width (Boyes et al., 2001). At maturity, these transformants would have as few as six basal leaves.

The dwarf and semi-dwarf phenotypes of these tmgetr1-1/hkers1 transformants are similar to the phenotypes observed in gibberellin-deficient 
mutants gai (GA insensitive), sly1 (sleepy 1), and pkl (pickle) (Fridborg et al., 1999). Gibberellin involved in functions in the plant such as, stimulation of epidermal cell elongation of the inflorescence stem, leaf expansion, flower development and induction of seed germination (Fridborg et al., 1999). Therefore, the dwarf and semi-dwarf phenotypes that were observed in these tmgetr1-1/hkers 1 transformants could be the first indication that there is cross-talk between the ethylene signal transduction pathway and the gibberellin signal transduction pathway. To date, no gibberellin receptor has been identified and the understanding of the gibberellin signaling pathway is still very basic (Fridborg et al., 1999).

In the future, when these tmgetr1-1/hkers 1 transformants are tested for their ability to germinate, if they demonstrate the poor germination phenotype, similar to that of the etr1-1 mutants, then this would be another indicator that the ethylene signaling pathway and the gibberellin pathway are linked. Since both etr1-1 and gibberellin deficient mutants demonstrate a poor germination phenotype this would be a reasonable hypothesis (Ecker, 1995; Fridborg et al., 1999). It could be that etr1-1 mutants are deficient in gibberellin or that they have a faulty gibberellin signaling pathway, since gibberellin is required for seeds to germinate (Debeaujon and Koornneef, 2000).

The severe developmental retardation of the transformants may be the result of overexposure to the hygromycin selection media. Hygromycin is a useful plant selection antibiotic because the selection of transformants is non ambiguous. However, one problem with hygromycin is that it is toxic even to 
resistant plants during long exposure. It can cause damage to the seedlings and abnormal development (Nakazawa and Matsui, 2003). The severe developmental retardation may also be the result of the high expression of the chimeric gene through the CaMV $35 \mathrm{~S}$ promoter or it may result from other reasons.

\subsection{Conclusion: Implications of the Constructs of this Project}

Several models have been suggested to explain the mode of ethylene signal transduction, from ligand binding to the activation of genes within the nucleus to exhibit the ethylene response. The first question that one might ask is, why does a single ethylene insensitive allele, such as etr1-1, preclude all other signaling-inactive receptors in the presence of ethylene, thereby conferring ethylene insensitivity to the entire seedling (Gamble et al., 2002)?

The reason for this may be that ethylene receptors are known to form homodimers (Schaller et al., 1995) and perhaps even heterodimers. However, this has not been demonstrated (Guo and Ecker, 2004). In fact, heterodimerization is a means by which other receptors, such as growth factor receptors, fine-tune signaling (Hall et al., 2000). If this were the case, then the mutated ethylene receptor from etr1-1 could form heterodimers with any of the 4 other ethylene receptors. As in the bacterial histidine kinases, the signal is transduced when there is an intermolecular phosphorylation, whereby one monomer phosphorylates the other monomer on a histidine residue (Schaller et al., 1995). If the phosphorylation event were the result of 
ethylene binding, it would not occur because ethylene would not be able to bind to this heterodimer, since the etr1-1 monomer lacks the ethylene binding copper cofactor (Zhoa et al., 2002).

The elimination of the ethylene receptors, ETR1, ETR2 and EIN4, that have response regulators, results in the activation of the ethylene response (Stearns and Glick, 2003). It is postulated that the ERS1 and ERS2 ethylene receptors, that lack receiver domains, use the receiver domains of the other ethylene receptors by forming heterodimers (Wang et al., 2003) or they use separate response regulators (Stepanova and Ecker, 2000).

Transformed plants of one of the pCambia 1301 constructs used in this project contains a chimeric gene composed of the transmembrane and GAF domain of ETR1 attached to the histidine kinase domain of ERS1. Therefore, this chimeric gene is lacking the response regulator domain. The CaMV $35 \mathrm{~S}$ promoter drives this gene and it is highly expressed. If ethylene receptors form heterodimers with other ethylene receptors (Wang et al., 2003), then the overwhelming number of chimeric ethylene receptors will result in the presence of heterodimers, predominantly composed of at least one if not two chimeric monomers. Therefore, most ethylene receptor dimers would not have a receiver domain or they would only have one receiver domain. This could have implications on downstream signaling events if each receptor plays a unique role in ethylene signaling (Hall et al., 2000). It may even result in the constitutive ethylene response if ERS1 and ERS2 rely solely on forming heterodimers with those receptors that possess a response regulator, in order 
to conduct signals downstream. This would result because the predominant receptors would consist of the chimeric proteins, which lack the response regulator domain. The receptors could not activate CTR1.

On the other hand, if ethylene receptors only form homodimers (Schaller et al., 1995) then this chimeric gene would be likely to form a homodimer with the inherent ETR1 protein because the disulfide-linked dimer is formed by cysteines 4 and 6 located with the transmembrane domain of ETR1 within the chimeric gene (Hall et al., 2000). Therefore, during signal transduction, if the phosphate is transferred from the histidine to the aspartate residue in trans from one monomer to the other (Hall et al., 2000), then the phosphate transfer could occur. This would allow the activation of CTR1 and therefore, the ethylene signaling pathway would behave normally. However, the predominant dimer would consist of two chimeric ethylene receptor proteins. Downstream signaling could only occur from these receptors if there are cognate response regulators. In this case, ethylene signaling would behave normally.

The other chimeric gene consists of the transmembrane and GAF domains of etr1-1 and the histidine kinase domain of ERS1. The principal hypothesis of this experiment is that when this gene is expressed in transformed plants, the $T_{1}$ seeds will germinate normally. Although, the seeds of etr1-1 mutants show poor germination in relation to wild-type plants (Ecker, 1995), the chimeric gene is not expected to induce this phenotype because it is lacking the response regulator domain normally found on etr $1-1$. The 
hypothesis implies that the response regulator domain is necessary to conduct the signal to downstream regulators in order to induce the poor germination phenotype.

The above scenario would be true only if ethylene receptors formed homodimers (Schaller et al., 1995). Since the CaMV 35S promoter drives this chimeric gene, it will be highly expressed. The predominant ethylene receptor will be the chimeric protein and therefore, in most cases two monomers of this chimeric protein will form a homodimer. If there are cognate response regulators, then the phosphorylation signal can be passed to the response regulators to mediate downstream responses. However, the signaling pathway through the cognate response regulators may or may not transmit the signal to the appropriate gene or genes that would result in the enhanced dormancy phenotype of the etr1-1 mutant. In regard to ethylene sensitivity, the chimeric gene homodimers would pass on the ethylene insensitivity signal to cognate response regulators if they were present. In other words, the transmission of the signal from the receptor to downstream effectors would occur and the plant would be ethylene insensitive. 


\section{References}

Alonso, J. M., T. Hirayama, G. Roman, S. Nourizadah, and J. R. Ecker. (1999). "EIN2, a Bifunctional Transducer of Ethylene and Stress Responses in Arabidopsis." Science 284: 2148 - 2152.

Alonso, J. M., A. N. Stepanova, R. Solano, E. Wisman, S. Ferrari, F. M. Ausubel, and J. R. Ecker. (2003). "Five components of the ethyleneresponse pathway identified in a screen for weak ethylene-insensitive mutants in Arabidopsis." Proc. Natl. Acad. Sci. USA. 100: 2992 - 2997.

Arabidopsis Genome Initiative. (2000). "Analysis of the genome sequence of the flowering plant Arabidopsis thaliana." Nature 408: 796 - 815.

Beaudoin, N., C. Serizet, F. Gosti, and J. Giraudat. (2000). "Interactions between Abscisic Acid and Ethylene Signaling Cascades." The Plant Cell 12: $1103-1115$.

Betts, M. J. and R. B. Russell (2003). Amino acid properties and consequences of substitutions. IN Bioinformatics fro Geneticists, Wiley.

Bleeker, A. B. and H. Kende (2000). "Ethylene: A Gaseous Molecule in Plants." Annu. Rev. Cell Dev. Biol. 16: 1 - 18.

Boyes, D., A. Zayad, R. Ascenzi, A. J. McCaskill, N. E. Hoffman, K. R Davis, and J. Gorlach. (2001). "Growth Stage-Based Phenotypic Analysis of Arabidopsis: A Model for High Throughput Functional Genomics in Plants." The Plant Cell 13: $1499-1510$.

Boyle, J. S. and A. M. Lew (1995). "An inexpensive alternative to glassmilk for DNA purification." Trends in Genetics 11(1): 8.

Chang, C., S. F. Kwok, Anthony B. Bleeker, and Elliot M. Meyerowitz. (1993). "Arabidopsis Ethylene-Response Gene ETR1: Similarity of Product to Two-Component Regulators." Science 262: 539 - 544.

Chen, Y.-F., M. D. Randlett, J. L. Findell, and G. E. Schaller. (2002). "Localization of the Ethylene Receptor ETR1 to the Endoplasmic Reticulum of Arabidopsis." The Journal of Biological Chemistry 277: 19861 - 19866.

Clark, K. L., P. B. Larsen, X. Wang, and C. Chang. (1998). "Association of the Arabidopsis CTR1 Raf-like kinase with the ETR1 and ERS ethylene receptors." Proc. Natl. Acad. Sci. USA 95: 5401 -5406.

Clough, S. J. and A. F. Bent (1999). "Floral dip: a simplified method for 
Agrobacterium-mediated transformation of Arabidopsis thaliana." The Plant Journal 16(6): 735 - 743.

Debeaujon, I. and M. Koorneef (2000). "Gibberellin Requirement for Arabidopsis Seed Germination is Determined Both by Testa Characteristics and Embryonic Abscisic Acid." Plant Physiology 122: 415 - 424.

Debeaujon, I., K. M. Leon-Kloosterziel, and M. Koornneef. (2000). "Influence of the Testa on Seed Dormancy, Germination, and Longevity in Arabidopsis." Plant Physiology 122: 403 - 413.

Dubreucq, B., P. Grappin, and Michel Caboche. (1996). "A new method for the identification and isolation of genes essential for Arabidopsis thaliana seed germination." Mol. Gen. Genet. 252: 42 - 50.

Ecker, J. R. (1995). "The Ethylene Signal Transduction Pathway in Plants." Science 268: 667 - 675.

Fridborg, I., S. Kuusk, T. Moritz, and E. Sundberg. (1999). "The Arabidopsis Dwarf Mutant shi Exhibits Reduced Gibberellin Responses Conferred by Overexpression of a New Putative Zinc Finger Protein." The Plant Cell 11: $1019-1031$.

Gamble, R. L., M. Coonfield, and G. E. Schaller. (1998). "Histidine kinase activity of the ETR1 ethylene receptor from Arabidopsis." Proc. Natl. Acad. Sci. USA 95: 7825 - 7829.

Gamble, R. L., X. Qu, and G. Eric Schaller. (2002). "Mutational Analysis of the Ethylene Receptor ETR1. Role of the Histidine Kinase Domain in Dominant Ethylene Insensitivity." Plant Physiology 128: 1428 - 1438.

Ghassemian, M., E. Nambara, S. Cutler, H. Kawaide, Y. Kamiya, and P. McCourt. (2000). "Regulation of Abscisic Acid Signaling by the Ethylene Response Pathway in Arabidopsis." The Plant Cell 12: 1117 1126.

Griffiths, A. J., J. H. Miller, D. T. Suzuki, R. C. Lewontin, and W. M. Gelbart. (2000). An Introduction to Genetic Analysis. New York, W. H. Freeman.

Guo, H. and J. Ecker (2004). "The ethylene signaling pathway: new insights." Current Opinion in Plant Biology 7: 40 - 49.

Hall, A. E. and A. B. Bleeker (2003). "Analysis of Combinatorial Loss-ofFunction Mutants in the Arabidopsis Ethylene Receptors Reveals that 
the ers1etr1 Double Mutant has Severe Developmental Defects that are EIN2 Dependent." The Plant Cell 15: 2032 - 2041.

Hall, A. E., Q. G. Chen, J. L. Findell, G. E. Schaller, and Anthony Bleeker. (1999). "The Relationship between Ethylene Binding and Dominant Insensitivity Conferred by Mutant Forms of ETR1 Ethylene Receptors." Plant Physiology 121: 291 - 299.

Hall, A. E., J. L. Findell, G. E. Schaller, E. C. Sisler, and A. B. Bleeker. (2000). "Ethylene Perception by the ERS1 Protein in Arabidopsis." Plant Physiology 123: 1449 - 1457.

Hebsgaard, S. M., P. G. Korning, N. Tolstrup, J. Engelbrecht, P. Rouze, and S. Brunak. (1996). "Splice site prediction in Arabidopsis thaliana premRNA by combining local and global sequence information." Nucleic Acids Research 24: 3459 - 3452.

Hua, J., C. Chang, Qi Sun and Elliot M. Meyerowitz. (1995). "Ethylene Insensitivity Conferred by ERS Gene." Science 269: 1712 - 1714.

Hua, J. and E. M. Meyerowitz (1998). "Ethylene Responses are Negatively Regulated by a Receptor Gene Family in Arabidopsis thaliana." Cell 94: $261-271$.

Hwang, I., H.-C. Chen, and Jen Sheen. (2002). "Two-Component Signal Transduction Pathways in Arabidopsis." Plant Physiology 129: 500 515.

Imamura, A., N. Hanaki, H. Umeda, A. Nakamura, T. Suzuki, C. Ueguchi, and T. Mizuno. (1990). "Response regulators implicated in His-to-Asp phosphotransfer signalling in Arabidopsis." Proc. Natl. Acad. Sci. USA 95: 2691 - 2696.

Katavic, V., G. W. Haughn, D. Reed, M. Martin, and L. Kunst. (1994). "In Planta transformation of Arabidopsis thaliana." Mol. Gen. Genet. 245: $363-370$.

Koorneef, M., L. Bentsink, and H. Hilhorst. (2002). "Seed dormancy and germination." Current Opinion in Plant Biology 5: 33 - 36.

Leon-Kloosterziel, K. M., G. A. v. d. Bunt, J. A. D. Zeevaart, and M. Koornneef. (1996). "Arabidopsis mutants with a Reduced Seed Dormancy." Plant Physiology 110: 233 - 240.

Lohrmann, J. and K. Harter (2002). "Plant Two Component Signalling 
Systems and the Role of Response Regulators." Plant Physiology 128: $363-369$.

Machabee, S. and H. S. Saini (1991). "Differences in the Requirement for Endogenous Ethylene During Germination of Dormant and NonDormant Seeds of Chenopodium album L." J. Plant Physiol. 138: 97 101.

Matilla, A. J. (2000). "Ethylene in seed formation and germination." Seed Science Research 10: $111-126$.

McCourt, P. (1999). "Genetic Analysis of Hormone Signalling." Annu. Rev. Plant Physiol. Plant Mol. Biol. 50: 219 - 243.

McGrath, R. B. and J. R. Ecker (1998). "Ethylene signaling in Arabidopsis: Events from the membrane to the nucleus." Plant Physiol. Biochem. 36(1-2): $103-113$.

Murashige, T. and F. Skoog (1962). "A Revised Medium for Growth and Bioassays with Tobacco Cell Cultures." Physiologia Planarum 15: 473 $-497$.

Nakazawa, M. and M. Matsui (2003). "Selection of Hygromycin-Resistant Arabidopsis Seedlings." BioTechniques 34: 28 - 30.

Ostergaard, L. and M. F. Yanofsky (2004). "Establishing gene function by mutagenesis in Arabidopsis thaliana." The Plant Journal 39: 682 - 696.

Ouaked, F., W. Rozhon, D. Lecourieux, and H. Hirt. (2003). "A MAPK pathway mediates ethylene signalling in plants." The EMBO Journal 22(6): $1282-1288$.

Raz, V. and R. Fluhr (1993). "Ethylene Signal is Transduced via Protein Phosphorylation Events in Plants." The Plant Cell 5: 523 - 530.

Sambrook, J. and D. Russel (2001). Molecular Cloning A Laboratory Manual. Cold Spring Harbour, NY, Cold Spring Harbour Laboratory Press.

Sambrook, J. F., E.F. Maniatis, T. (1989). Molecular cloning: a laboratory manual. Cold Spring Harbor, Cold Spring Laboratory Press.

Schaller, G. E., A. N. Ladd, M. B. Lanahan, J. M. Spanbauer, and A. B. Bleeker. (1995). "The Ethylene Response Mediator ETR1 from Arabidopsis Forms a Disulfide-linker Dimer." The Journal of Biological Chemistry 270(21): $12526-12530$. 
Stearns, J. C. and B. R. Glick (2003). "Transgenic plants with altered ethylene biosynthesis or perception." Biotechnology Advances 21: 193 - 210.

Steber, C. M. and P. McCourt (2001). "A Role for Brassinosteroids in Germination in Arabidopsis." Plant Physiology 125: 763 - 769.

Stepanova, A. N. and J. R. Ecker (2000). "Ethylene signalling: from mutants to molecules." Current Opinion in Plant Biology 3: 353 - 360.

Urao, T., S. Miyata, K. Yamaguchi-Shinozaki, and K. Shinozaki. (2000). "Possible His to Asp phosphorelay signaling in an Arabidopsis twocomponent system." FEBS Letters 478: 227 - 232.

Vriezen, W. H., P. Achard, N. P. Harberd and D. Van Der Straeten. (2004). "Ethylene-mediated enhancement of apical hook formation in etiolated Arabidopsis thaliana seedlings is gibberellin dependent." The Plant Joumal 37: $505-516$.

Wang, K. L.-C., H. Li, and J. R. Ecker. (2002). "Ethylene Biosynthesis and Signalling Networks." The Plant Cell: S131 - S151.

Wang, M. and P. Waterhouse. (1997). "A Rapid and Simple Method of Assaying Plants Transformed with Hygromycin or PPT Resistance Genes." Plant Molecular Biology Reporter 15: 209 - 215.

Wang, W., A. E. Hall, Ronan O'Malley and Anthony B. Bleeker. (2003). "Canonical Histidine kinase activity of the transmitter domain of the ETR1 ethylene receptor from Arabidopsis is not required for signal transmission." Proc. Natl. Acad. Sci. USA. 100(1): 352 - 357.

Zhao, X.-C., X. Qu, D. E. Mathews, and G. E. Schaller. (2002). "Effect of Ethylene Pathway Mutations upon Expression of the Ethylene Receptor ETR1 from Arabidopsis." Plant Physiology 130: 1983 - 1991. 